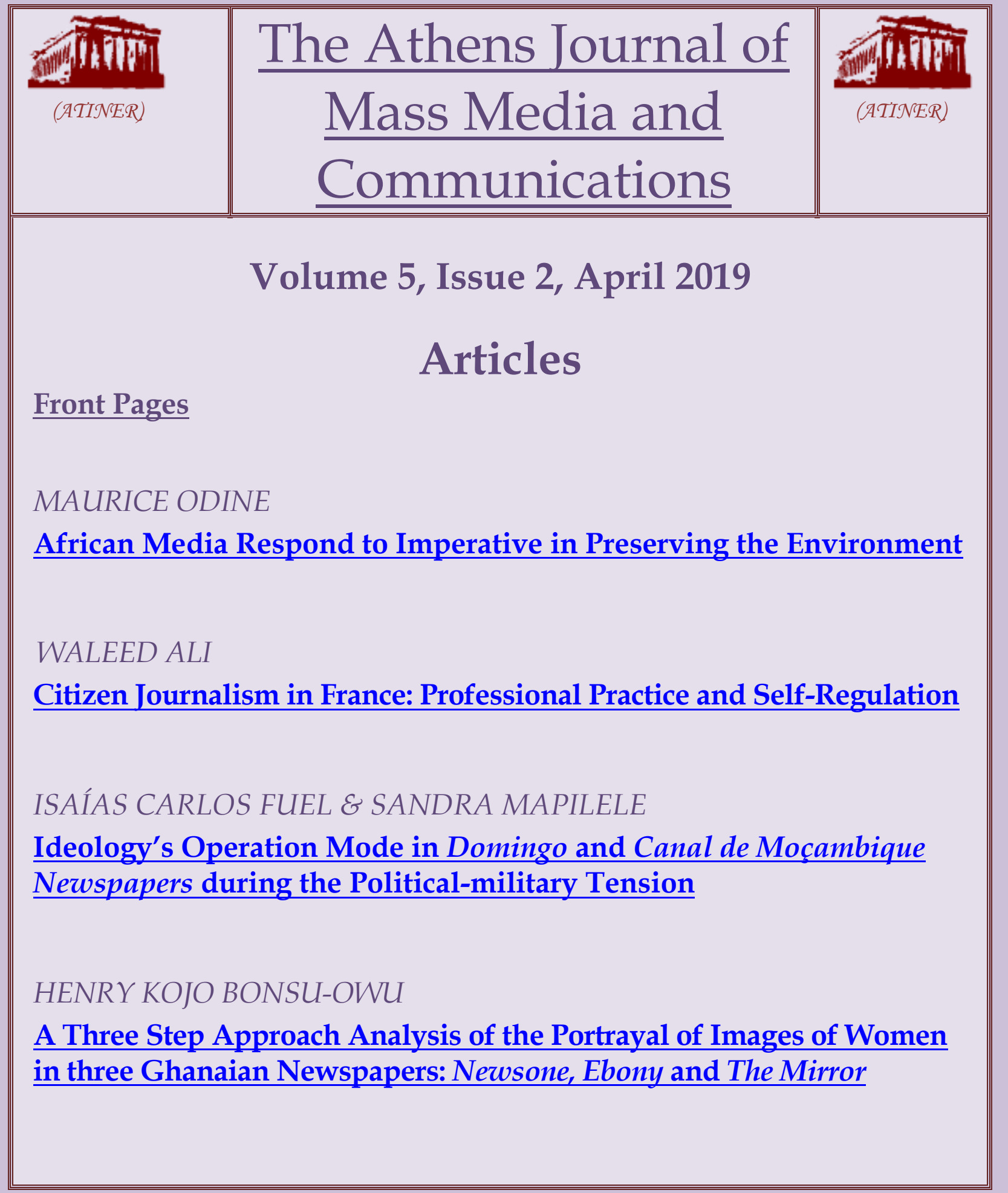




\section{Mission}

ATINER is a World Non-Profit Association of Academics and Researchers based in Athens. ATINER is an independent Association with a Mission to become a forum where Academics and Researchers from all over the world can meet in Athens, exchange ideas on their research and discuss future developments in their disciplines, as well as engage with professionals from other fields. Athens was chosen because of its long history of academic gatherings, which go back thousands of years to Plato's Academy and Aristotle's Lyceum. Both these historic places are within walking distance from ATINER's downtown offices. Since antiquity, Athens was an open city. In the words of Pericles, Athens"... is open to the world, we never expel a foreigner from learning or seeing". ("Pericles' Funeral Oration", in Thucydides, The History of the Peloponnesian War). It is ATINER's mission to revive the glory of Ancient Athens by inviting the World Academic Community to the city, to learn from each other in an environment of freedom and respect for other people's opinions and beliefs. After all, the free expression of one's opinion formed the basis for the development of democracy, and Athens was its cradle. As it turned out, the Golden Age of Athens was in fact, the Golden Age of the Western Civilization. Education and (Re)searching for the 'truth' are the pillars of any free (democratic) society. This is the reason why Education and Research are the two core words in ATINER's name. 
The Athens Journal of Mass Media and

Communications

ISSN NUMBER: 2407-9677 - DOI: 10.30958/ajmmc

Volume 5, Issue 2, April 2019

Download the entire issue ( $\underline{\mathrm{PDF}})$

Front Pages

i-viii

African Media Respond to Imperative in Preserving

73

the Environment

Maurice Odine

Citizen Journalism in France: Professional Practice and

93

Self-Regulation

Waleed Ali

Ideology's Operation Mode in Domingo and Canal de

Moçambique Newspapers during the Political-military Tension

Isaías Carlos Fuel \& Sandra Mapilele

A Three Step Approach Analysis of the Portrayal of Images of Women in three Ghanaian Newspapers:

Newsone, Ebony and The Mirror

Henry Kojo Bonsu-Owu 


\section{The Athens Journal of Mass Media and Communications Editorial and Reviewers' Board}

$\underline{\text { Editors }}$

- Dr. John Pavlik, Head, Mass Media and Communication Unit, ATINER \& Professor, Journalism and Media Studies, School of Communication and Information, Rutgers University, USA.

- Dr. Yorgo Pasadeos, Director, Social Sciences Division, ATINER \& Professor Emeritus, University of Alabama USA.

- Dr. Patrick Vyncke, Professor of Communication Management, Department of Communication Sciences, Ghent University, Belgium.

\section{Editorial Board}

- Dr. John Pavlik, Head, Mass Media and Communication Unit, ATINER \& Professor, Rutgers University, USA.

- Dr. Burak Dogu, Academic Member, ATINER \& Vice Dean, Izmir University of Economics, Turkey.

- Dr. Andzela Armoniene, Head of The Fund Young Researcher, Lithuania.

- Dr. Mariam Gersamia, Professor \& Head, Division of Journalism and Mass Communication, Ivane Javakhishvili Tbilisi State University, Georgia.

- Dr. Egle Jaskuniene, Associate Professor \& Vice Dean for Research, Faculty of Creative Industries, Vilnius Gediminas Technical University, Lithuania.

- Dr. Berrin Yanikkaya, Academic Member, ATINER and Professor \& Head, School of Communication Studies, Auckland University of Technology, New Zealand.

- Dr. Dali Osepashvili, Professor, Department of Journalism and Mass Communication, Ivane Javakhishvili Tbilisi State University, Georgia.

- Dr. Walter Wymer, Academic Member, ATINER \& Professor of Marketing, University of Lethbridge, Canada.

- Dr. Alan Albarran, Academic Member, ATINER \& Professor, The University of North Texas, USA.

- Dr. Patricia L. Dooley, Elliott Distinguished Professor of Communication, Wichita State University, USA.

- Dr. Catherine Ann Collins, Professor, Department of Rhetoric, Willamette University, USA.

- Dr. Pamela Doyle Tran, Professor of Electronic News, University of Alabama, USA.

- Dr. S. Andrews, Professor, Department of Information Technology, Mahendra Engineering College, India.

- Dr. Emmanuel Ngwainmbi, Department of Communication Studies, The University of North Carolina, USA.

- Dr. Zsolt Alfred Polgar, Academic Member, ATINER \& Associate Professor, 
Technical University of Cluj-Napoca, Romania.

- Dr. Margaret M. Cassidy, Academic Member, ATINER \& Associate Professor, Adelphi University, USA.

- Dr. Baris Coban, Associate Professor, Communication Sciences Department, Dogus University, Turkey.

- Dr. Ulas Basar Gezgin, Associate Professor of Applied Communication, British University Vietnam, Vietnam.

- Dr. Anya Luscombe, Associate Professor and Head, Department of Academic Core, University College Roosevelt, The Netherlands.

- Dr. Charles Obot, Academic Member, ATINER \& Associate Professor, University of Uyo, Nigeria.

- Dr. Ceren Sozeri, Associate Professor, Faculty of Communication, Galatasaray University, Turkey.

- Dr. Matthew D. Matsaganis, Assistant Professor, Department of Communication, State University of New York (SUNY), USA.

- Dr. Geneviève A. Bonin, Assistant Professor, University of Ottawa, Canada.

- Dr. Klarissa Lueg, Assistant Professor, Aarhus University, Denmark.

- Dr. George Pavlou, Assistant Professor, European University, Cyprus.

- Dr. Yolandi Slabbert, Senior Lecturer, Department of Communication Science, University of South Africa, South Africa.

- Dr. Daniel Binns, Academic Member, ATINER \& Lecturer, RMIT University, Australia.

- Dr. Binoy Kampmark, Lecturer in Social Sciences, School of Global, Urban and Social Studies, RMIT University, Australia.

- Dr. Sarah Sparke, Academic Member, ATINER \& Research Associate, CMIR, University of the West of England, UK.

- Dr. Vittoria Sacco, Postdoctoral Assistant, Neuchatel University, Switzerland.

- Ms. Mania Alehpour, PhD Candidate, University of Tehran, Iran.

- General Managing Editor of all ATINER's Publications: Ms. Afrodete Papanikou

- ICT Managing Editor of all ATINER's Publications: Mr. Kostas Spyropoulos

- Managing Editor of this Journal: Ms. Zoi Charalampous (bio)

\section{Reviewers' Board}

Click Here 


\section{President's Message}

All ATINER's publications including the e-journals are open access without any costs (submission, processing, publishing, open access paid by authors, open access paid by readers etc) and are independent of the presentations made at any of the many small events (conferences, symposiums, forums, colloquiums, courses, roundtable discussions) organized by ATINER throughout the year. The intellectual property rights of the submitted papers remain with the author.

Before you submit, please make sure your paper meets some basic academic standards, which include proper English. Some articles will be selected from the numerous papers that have been presented at the various annual international academic conferences organized by the different divisions and units of the Athens Institute for Education and Research.

The plethora of papers presented every year will enable the editorial board of each journal to select the best ones, and in so doing, to produce a quality academic journal. In addition to papers presented, ATINER encourages the independent submission of papers to be evaluated for publication.

The current issue of the The Athens Journal of Mass Media and Communications (AJMMC) is the second issue of the fifth volume (2019). The reader will notice some changes compared with the previous issues, which I hope is an improvement.

Gregory T. Papanikos, President

Athens Institute for Education and Research 


\section{Athens Institute for Education and Research}

A World Association of Academics and Researchers

17th Annual International Conference on Communication and Mass Media, 13-16 May 2019, Athens, Greece

The Mass Media \& Communication Research Unit of the Athens Institute for Education and Research (ATINER) organizes its 17 th Annual International Conference on Communication and Mass Media, 13-16 May 2019, Athens, Greece sponsored by the Athens Journal of Mass Media and Communications. The aim of the conference is to bring together academics and researchers of Communications, Mass Media and other related disciplines. Please submit a proposal using the form available (https://www.atiner.gr/2019/FORM-MED.doc).

- Abstract Submission: 1 April 2019

- Acceptance of Abstract: 4 Weeks after Submission

- Submission of Paper: 15 April 2019

\section{Academic Members Responsible for the Conference}

- Dr. John Pavlik, Head, Mass Media and Communication Research Unit, ATINER \& Professor, Rutgers University, USA.

- Dr. Yorgo Pasadeos, Director, Social Sciences Division, ATINER \& Professor Emeritus, University of Alabama USA.

\section{Social and Educational Program}

The Social Program Emphasizes the Educational Aspect of the Academic Meetings of Atiner.

- Greek Night Entertainment (This is the official dinner of the conference)

- Athens Sightseeing: Old and New-An Educational Urban Walk

- Social Dinner

- Mycenae Visit

- Exploration of the Aegean Islands

- Delphi Visit

- Ancient Corinth and Cape Sounion

\section{Conference Fees}

Conference fees vary from $400 €$ to $2000 €$

Details can be found at: https://www.atiner.gr/2019fees 


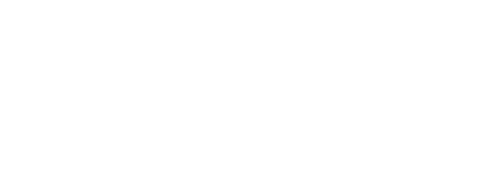




\title{
African Media Respond to Imperative in Preserving the Environment
}

\author{
By Maurice Odine ${ }^{*}$
}

\begin{abstract}
As the second largest continent, Africa perpetually faces environmental problems that put populations at risk, often resulting in massive destruction and sometimes death. The ChadianCameroon Oil Pipeline, Bypass Project in Mozambique and Ogoni-land Nigerian project are examples of the devastation brought about by the dollar-seeking countries and Western-style oil-drilling companies. The telecommunication company, Huawei, has established 40 offices on the continent aimed at training Africans on environmental communication using digital technology. To raise awareness, the Stockholm Challenge emphasizes environmental justice and sustainable development. Despite achieving statehood only in 1994, the government of South Africa has condemned environmentally-induced poverty. Elsewhere, concerned Paul and Anne Ehrlich (1990) published, "The Population Explosion", which highlighted the planet's depleting resources. In the blog, "Environmental Communication 2015", Andrew Revkin focuses on youth and solicits the latter's ideas, ranging from library books and multiple channels to social and digital media. East African countries have formed the population, health and environment (HEP) union committed to environmental communication to protect planet earth.
\end{abstract}

Keywords: Africa, communication, ecosystem, environment, information.

\section{Introduction}

Humans and other creatures owe their survival to the environment, namely, food, water and habitat. However, humans have continued to cause impurity, degradation, and even devastation to the environment, causing health hazards and environmental malaise. It is the latter that has given birth to environmental communication. Ethel Kennedy, in the publication, "The Chad Cameroon Oil and Pipeline Project: Putting People and the Environment at Risk", raises grave concern. The writer quotes the well-known leader, Archbishop Desmond Tutu, as saying, "Africa cannot afford the environmental devastation of such a project. We need to help construct, not to destroy it". Making reference to the Chad-Cameroon Oil and Pipeline project, the writer laments that it will exacerbate environment devastation, social disruption and human rights violations. Similarly, the writer draws attention to the Ogoni-land debacle in Nigeria as a traumatic reminder of what happens when the rights of a people and their environment are trampled. Desmond Tutu may have just predicted the coming of a large-scale oil company solely dependent on gains extorted from the environment.

The chief executive officer of MarEUSAID adds, "If they insist on such measures, foreign investment might go elsewhere". Ethel Kennedy (1999) is bemused because these pronouncements are contrary to the World Bank

*Professor, Department of Radio-Television \& Film, Texas Southern University, USA. 
Group's goals: poverty alleviation and sustainable development, and not gambling with the lives and future of Africans. Bully tactics, and forceful degradation of Africa's livelihoods in pursuit of petro-dollars, is totally inhumane and sidesteps well-known environmental hazards.

It is in this context that Kaya, Ruffin, and Teffo (2016) writing in "African Indigenous Languages and Environmental Communication", argue that the desired change in environmental conservation can only be achieved if information appeals to the cultural values of the recipients. "African indigenous languages are the best vehicles of communicating environmental information as they are cultural specific", state the authors.

Although the scientific community and lawmakers are aware of the dangers of a hazardous environment, media have reported the issue as deeply rooted in conflict and uncertainty. To this end, environmental communication has taken an entirely multidisciplinary perspective, examining how environmental issues develop; entertaining various viewpoints; and researching the relevant scientific and technical information. Historically, South Africa was irrelevant and unimportant. The majority black citizens (79 percent) were uprooted and transplanted at will by the racial, white-only government (apartheid) to restrict black movement and population growth.

Pursuing an environmental sustainability policy, the new South Africa participated in the 1992 United Nations Conference on Environment and Development (UNCED). In 2009, East Africa nations met in Kigali (Rwanda) to reaffirm their commitment to examine linkages between the population and the environment. In March 2015, President Abdel Fattah el-Sisi of Egypt and Prime Minister Haile Mariam Desalegn of Ethiopia signed a "Declaration of Principles" on the Nile hydropower dam. Furthermore, networks have emerged in different parts of Africa to program and disseminate information, along with environmental analyses and features and opinions. The pursuant mediaenvironment union is mutually inclusive.

It is this union that gave birth to the population, health and environment (PHE) championed by Ethiopia, Kenya, Rwanda, Tanzania and Uganda. Jason Bremner is program director at Population, Health and Environment at the Population Reference Bureau. The writer describes PHE as an intergovernmental network designed to provide leadership and promote sustainable development in Eastern Africa. In this endeavor, member countries facilitate an active network for information exchange, professional networking, capacity building and collaborative advocacy to raise awareness about PHE issues aimed at cross-sector integration. Speaking for the majority of African nations at a policy meeting in March 2009 in Rwanda, the Minister of Natural Resources, Stanislaus Kamanzi, noted: "[Africa] faces great challenges, many of which are related to the complex relationships between population trends, poverty and environmental conditions" ${ }^{1}$.

The delegates and the minister's proclamations would come to naught without information and communication. This partly explains why the two-day

\footnotetext{
${ }^{1}$ Kamanzi, S. (2009, March 25). https://www.prb.org/rwandaphenetwork/.
} 
meeting devoted sufficient attention to formulating a communications advocacy policy. In this regard, representatives worked in groups to develop ways to translate knowledge into action, using knowledge and coalition building and agenda setting to create channels to disseminate information on the environment. Furthermore, participants agreed to create communication strategies best suited for respective countries and audiences, and in relation to PHE.

Coalition building has not escaped the commendable work by the United States (US) Agency for International Development (USAID). Two projects supported by USAID integrated aspects of population, health and the environment service delivery. The macro-level relationships inherent in the projects are examples of how innovative solutions can be used to further communication and advocacy in the interest of the environment. On the importance of the subject, Jason Bremner has praised Africa's initiatives on the environment, affirming that, "...[In the] African region where men, women, and children are healthy, the environment is conserved, and livelihoods are secure".

One glaring reason is survival, which translates into food chain as an example of a useful component of the ecosystem. Encyclopedia Britannica explains that, plants use sunlight, water and elements in soil and air to create food for them. They are eaten in turn by animals and micro-organisms. Humans find themselves at the top of the food pyramid in any eco-system because they use plants and animals for food. Earthworms and small insects (bees, pollinating plants) are all part of the environment, without which the food chain would be broken.

According to the Food and Agriculture Organization (FAO) of the United Nations, world production can be gauged when one considers that, as much as 2,533 million tons of cereals were grown in 2015. Meanwhile, the University of Minnesota points out that, the nutritional value of food has decreased since the 1950s, "so we are now getting less nutrition per calorie in our foods". Brian Halweil (2007) of the Organic Center explains that crop increase in crop yield corresponds with decrease in nutritional value. What is the reason? It is because industrial farming relies on monoculture and the excessive use of chemicals as fertilizers and pesticides which upset many of the natural processes. The center calls on humans on Earth to consider the environment vitally important; humans should not disrupt the chain as such action would adversely affect food growth.

It is true Africa and Africans are not oblivious to existential threats posed by an unfriendly environment. John Muthee (2018) writes under the title, "Serving and growing with Africa: How Huawei enriches life through Communication". The writer praises Huawei Technologies for going beyond commercialization to enrich the lives of Africans by providing communications network solutions. John Muthee regrets the prevalence whereby corporate profits have relegated human service to irrelevant doldrums, commending the telecommunications company on "enriching the life of Africans with the diversified communication services offered by affiliate telecom companies". 
The writer notes that, Huawei is pursuing a mission to address the economic and geographic imbalance by bridging the digital divide through empowerment of local telecommunication expertise.

It is to this end that Huawei has successfully customized competitive telecommunications solutions and given African populations the rare opportunity to take part in the information society and to enable citizens to acquire training and technological know-how. In this regard, Huawei has set up six training centers in Africa which have thus far graduated over 12,000 technical experts to serve in community centers.

As for the environment, the writer recognizes a noteworthy trio, that is, Green Huawei, Green Communication and Green World. It is not only functional, but also well established that environmental deterioration and accelerated global warming has surfaced as issues for mankind. Telecommunication technologies have contributed not only to reduced energy consumption, but also carbon reductions in dioxide emissions since telephone calls and teleconferences have since eliminated non-essential travel.

Huawei's goal resides in its trio: Green Huawei, Green Communications and Green World). To enhance this goal, the company has established branch offices in more than 40 African countries that include sales and services, technical and manufacturing centers. These initiatives have led to the hiring of talented Africans to enter the field of communication, and are charged with conceptualizing and disseminating information on environmental protection.

Indeed, the road to environmental protection starts with education. Professor Helen Correll teaches Environmental Communications at Metropolitan State University (member of Minnesota State University System). According to the syllabus, the "course focuses on environmental communication which encompasses a multidisciplinary viewpoint". The course attempts to enable students to understand how environmental issues and conflicts develop; the values underlying the perspectives on these issues; and the scientific and technical information involved in understanding environmental communication.

"We also look at how environmental values can be conveyed throughout a variety of media", says Dr. Correll on the syllabus ${ }^{2}$. The professor states course objectives as follows:

- Understand the complexities of environmental issues;

- Analyze the underlying values that propel disagreements;

- Understand the role of scientific and technical writing in environmental issues; and

- Establish guidelines for affective environmental communication.

Course procedure does include discussion on various environmental communication issues, with students contributing mostly to the discussion. The

2 Correll, H. (N.D.). Environmental Communication Course Syllabus. Retrieved from https://theieca.org/sites/default/files/syllabi/correll.pdf 
weekly class meeting covers a specific issue following prior preparation by students based on assigned readings. Projects include individual annotated bibliography of about 20 to 25 entries on a topic of their choice in environmental communication, with sufficient copies to share with class mates. A final requirement is a graduate project or research paper synthesizing what the student has learned in the course. The paper consulted books, journal articles and magazines on the subject under investigation. Relevant online sources form part of the research effort. These secondary sources are used for purposes of interpretation and analysis.

A number of research topics are then considered. Topic one lays down the case for Africa's environment. Topic two looks at communicating environmental risk. Topic three studies the raison d'être of environmental communication. And topic four assesses youth relationship with environmental communication.

Topic one lays out a comprehensive and integrated analysis of the continent's environment, equally noting the complex interplay between natural events and the impact of human actions on the environment. Topic two describes a case involving risk management and how the risk was communicated to stakeholders and the people whose habitat was affected. Topic three deals with the imperative to prevent the ruin of mankind's ecosystem, let alone impending perils to humans and youth to whom the future belongs. And topic four highlights the need to create environmental communication awareness among the youth.

\section{Literature Review}

\section{Environmental Degradation in Africa}

One would tend to think conventionalism would be on mankind's side when the environment is concerned. However, torture and desperation proliferate to wreak havoc on even the frail and helpless. James Wolfensohn (1999) comments: "Seeking equity when government is riddled with corruption and has inefficient and untrained officials is an objective that will never be realized". The front page of the article, "The Chad Cameroon Oil and Pipeline Project: Putting People and the Environment at Risk", shows a man [photo by Korina Horta] in his mid-thirties.

In his hands are a wooden bow and arrow. He is standing in the middle of a dirt road lined on both sides with dust-laden shrubs, green grass and bushes. The man is wearing a wrinkled brown shirt, standing in the middle of a dirt road, with the back against the green vegetation. He is without shoes; his feet and toes show accumulated dust and sand. The man's long-sleeved jacket holds on; his left shoulder saddled with a bag. His face is solemn, polite, but stern, as if to say, "What's next for me?" or "Do I have a future?" It is a calculation in view of desperation, as if to exhibit the rock-bottom of his fate or life's gloomy 
outlook. The man is an example of the environmental degradation that continues to plague Africa's populations.

In 1999, the Environmental Defense Fund reported the Chad Cameroon Oil and Pipeline Project would construct 300 oil wells in the Doha fields of Southern Chad; construct a 650-mile pipeline from Doha through Cameroon to the Atlantic; build a marine pipeline at Kribi to a floating storage offloading (FSO) vessel; and produce 225,000 barrels per day. The final project's financial arrangements placed Exxon-Mobile to earn 40 percent, while ELF (French company) stood to earn 20 percent. Esso, a European conglomerate, came in much lower. The total estimated cost of the oil project was $\$ 3.5$ billion. According to Amnesty International, the Chadian government was responsible for killing hundreds of civilians in the oil-producing region, and for the disappearance and murder of civilians while in police custody.

Access to information on the environmental degradation in the region have been dismissed or marginalized by the Chadian and Cameroon governments. Critical, too, is lack of information on compensation for farmers who have lost trees and crops as part of the project. In Cameroon, it was only after years of criticism that the compensation rate for one mango tree jumped from mere $\$ 6.58$ to $\$ 9,400$. The environmental degradation of the mango tree is economically ruinous since it takes three- to five-years, from when it is planted to the time it bears fruit. In their mostly rural and land-locked communities, one step forward is to educate Africa's population on their environment.

\section{Environmental Awareness through Education}

Education, therefore, stands to play a major role in Africa's environmental communication. From a positive viewpoint, the Stockholm Challenge is entitled, "Awareness raising and education about Africa Environmental Justice and Sustainable Development Challenges (1995-2011)"3. Besides addressing concerns embedded in the title, the organization serves a dual purpose. First, it serves as a tool to communicate to the international community with the purpose of raising awareness about Africa's environmental challenges. Second, it has as a goal to combat poverty by promoting socio-economic development. How can this be achieved?

The unit organizes public education and is creating awareness through Internet using online groups, newsletters, bulletins, blogs, conferences and websites. These channels of communication are used to disseminate and facilitate information exchange, as well as debate and learning. Meanwhile, Millennium Development Goals is an agenda of the Stockholm Challenge. It is intended to address the environment, natural resource management, sustainable development and climate change in Africa. Additionally, the goals for education, communication and awareness involve discussion and exchange of ideas, experiences, news, case studies, policies and practices as they related to the environment and sustainable development.

\footnotetext{
${ }^{3}$ https://sustainabledevelopment.un.org/topics/africa/decisions
} 
At this juncture, about 500 African countries and non-governmental organizations (NGOs) take advantage of the program's work. Boykoff and Roberts (2007) embrace history. The authors assert that, international and domestic environmental policy began in the mid-1980s. These activities were championed by the International Council of Scientific Unions (ICSU), the United Nations Environmental Program (UNEP) and the World Meteorological Organization (WMO).

Consequently, content meant for mass dissemination cannot ignore harnessing information communication technology (ICT). It cannot be denied that, the well-known digital divide has resulted in a lack of access to information among African populations. Hence, the gap between developed and developing countries to obtain and utilize information has widened. Consequently, the lack of information remains a major hindrance to economic, scientific and technological development in Africa. The lack of Internet service and other channels of information, at home or work, has had retrogressive consequences on the continent. Moreover, there are no community libraries; books are expensive; and it is hard to find publications that focus on environmental communication. Notwithstanding, many people rely on Internet connections in the cafés or public places.

At a time when other nations are bombarded with information and related technology, a typical African is starved of information. To alleviate the status quo, the Stockholm Challenge has taken certain steps to provide communication and to create awareness. These steps include collecting, editing and distributing information to e-groups and e-newsletters; updating and maintaining a website to disseminate information on case studies, links, experiences, ideas on environmental communication; as well as managing information technology e-mail groups and e-newsletters using text and HTML, Blogger, Microsoft Word, Excel, Publisher and InDesign.

The important role of environmental communication is more apparent in view of the absolute certainty of the role and livelihood of future generations. In this context, youth's interdisciplinary education assures that information is conceptualized and managed and disseminated to a pluralism of audiences with a view to maintaining an eco-friendly environment. According to the University of Wisconsin (Oshkosh), "Environmental communication pertains to any profession which communicates an environmental or scientific message. This message can range from conservation of resources, promotion of products, to education about community programs". Quite often, the environment's natural resources are depleted, leaving behind an array of insurmountable problems ranging from mankind's substance to survival. These conditions require information know-how to counter conflicting propagandistic environmental communication by sophisticated professionals.

The university's curriculum recognizes that, effective communication of any environmental message can determine the fate of an environmental campaign at the local, regional or national level.

A simple question is: "What do those in environmental communication do?" Actually, environmental communicators do the following: 
- Communicate the importance of conservation to the public, governmental agencies and private corporations;

- Convey the responsible agency's commitment to good environmental stewardship;

- Persuade others of the need for compliance with environmental regulations;

- Share information with media about environmental issues;

- Write speeches on the virtues of a healthy environmental; and

- Help sell environmentally-safe products.

Certain skills are necessary to be an effective environmental communicator. These include:

- public speaking: the ability to articulate views efficiently and positively in various formats, including a speech, panel, debate, and group discussion;

- writing skills: effective and efficient writing;

- interpersonal skills: conflict resolution, negotiation, and community building, and) computer skills: not only word-processing, but also spread sheets and computer presentation (PowerPoint).

Qualities include the ability to convey information in a clear and efficient way while demonstrating care for the environment; ability to understand multiple and opposing viewpoints and responding to them in an informed, clear way; and a strong commitment to the well-being of the environment, plus a strong desire to work against those who are destructive of nature.

\section{Network for Environmental Communication}

The thrust in environmental communication is recognizing that ICT cannot do it alone. ICT is to work in partnership with other types of media or channels. There is an adage that one medium complements another. As deity would will it, the United Nations Environment Program (UNEP) is headquartered in Nairobi, Kenya. In a press release on 20 September 2017, under the caption, "UN Environment and Discovery Communications Partner to Engage World on Environmental Action", UNEP announced a dynamic partnership to bring about awareness regarding the planet's most pressing environmental challenges and to highlight innovative solutions to address them.

The UN agency has developed strategies to develop original content on the environment with a view to encouraging individuals and communities to make

\footnotetext{
${ }^{4}$ UNEP (2017, September 20). Retrieved from https://corporate.discovery.com/discoverynewsroom/un-environment-and-discovery-communications-partner-to-engage-world-onenvironmental-action/
} 
a difference in utilizing content for dissemination using digital and social media, including Discovery Channels and UN media apparatus. "Together with the UN, Discovery will use its global platforms to amplify our share stories and message around the world and make a lasting difference for our planet", said Erik Solheim, head of UNEP ${ }^{5}$.

\section{Findings}

\section{The Case for Africa's Environment}

The paper on environmental communication is likely to add to the urgency of addressing issues of grave concern to the environment which, after all, is habitat to natural resources, mankind and animals. It is, therefore, no surprise that, the Environment Outlook (AEO) ${ }^{6}$ report lays out a comprehensive, integrated analysis of the continent's environment. The report contains a detailed analysis of the state of the environment in Africa, indicating discernible trends. It equally notes the complex interplay between natural events and the impact of human actions on the environment. Contextually, AEO (2013) analyzes the effects of environmental change in terms of human vulnerability and security. In so doing, it presents a set of circumstances on Africa's environmental outlook and makes recommendations for policy actions:

- Atmosphere: Africa is vulnerable to climate variability and climate change. Variations in rainfall have resulted in drought and flooding, sometimes with disastrous consequences for populations and the environment;

- Biodiversity: Africa's biological resources are declining rapidly as a result of habitat loss, overharvesting of selected resources and illegal activities. Although formal protection has been strengthened at the national and international levels over the past 30 years, additional measures are required, particularly as it relates to indigenous knowledge and involvement of stakeholders;

- Coastal and marine habitats: Overharvesting of Africa's coastal resources and poor inland management is unfriendly to the environment; oil pollution is a threat to resources, habitats and economies located along the African coastline;

- Forests: Africa has the world's fastest deforestation growth rate. This has caused loss of resources, imperiled livelihoods, energy dependence and threatened alternative energy sources;

\footnotetext{
${ }^{5}$ Eric Solheim is an official at UN Environmental Protection Program in Nairobi, Kenya. ${ }^{6}$ Africa Environmental Outlook (AEO), (2013). Retrieved from https://www.unenvironment.org/resources/report/african-environment-outlook-3-aeo-3-summarypolicy-makers
} 
- Fresh and Clean water: Unavailability of fresh and clean water remains a limiting factor for development in Africa. The condition constraints food production and industrial activities, contributing significantly to the burden of disease;

- Land: Degradation of soil and vegetation is largely due to increased population pressures. Thus, inequitable land access has brought about poverty; decline in agricultural yields and food security; and an increased potential for conflict; and

- Urbanization: Although most Africans live in rural areas, the continent's rate of urbanization is among the highest in the world. Poor economic growth, coupled with low investment in infrastructure, has impeded the provision of housing and basic services in urban areas.

Even a young nation such as South Africa recognizes the need to urbanize as part of a national plan to improve the environment for human life and future generations. Five years after independence in 1994, and the birth of a nonracial and apartheid-free democracy, the Minister of Environmental Affairs and Tourism, Mohammed Valli Moosa ${ }^{7}$, regrets that 20 percent of the country's population lives in poverty. Many of the households in this category do without pipe-borne water, adequate sanitation, waste disposal services, let alone limited access to health care and education. "In contrast, the wealthiest ten percent of South Africans account for 35 percent of all expenditure. They use many more resources and create more waste", said the minister on 26 October 1999.

The minister was adamant about the imperative for a healthy environment capable of supplying raw materials, absorb and tear waste products, while maintaining a free flow of clean water, soil preservation and air quality. As articulated by Moosa, the essentials to a healthy environment are food security, water provision and climate sustainability. These essentials depend on functioning ecosystems; acceptable levels of biodiversity; sustainable rates of resource extraction and minimal production of waste and pollution.

Coming to the rescue of the environment, the minister announced the launching the State of Environment Reporting in South Africa. It is a crafted plan to improve access to environmental information. Although the plan is still in its early stages, Minister Moosa is optimistic: "We are able to provide information on national environmental issues, select local environmental issues and make comparisons between them and with other countries and cities around the world".

However, information can only be effective if it is supported by other mechanisms, including the capacity of decision makers and financial resources to monitor environmental conditions and implement intervention strategies. South Africa's plan on information for the environment is the first, and only, on the continent. The minister's core message is direct: "...We are giving the

7 Moosa, Valli is former Minister of Environmental Affairs and Tourism. https://corporate.suninternational.com/about/directors/valli-moosa/ 
people of this country [South Africa] access to a very powerful tool: the knowledge of the environment in which they live and work".

Knowledge of the environment is not unrelated to the poverty of most African populations. It is related to their dependence on natural resources, despite their vulnerability to environmental vicissitudes. For more than 40 years, poverty has continued to worsen in Africa and the region's environment has also deteriorated. As a result, Africans find themselves more vulnerable to environmental change.

If there is a puzzle for Africa, it is untangling the intricacies embedded in wonders of encoder-message-decoder that is encapsulated in the practice of effective communication. As a matter of fact, it is all about environmental communication, without which the plight facing the African environment will remain unchecked. This is why the media must disseminate information on the environmental. Accordingly, information is to be targeted toward diverse audiences, governments and related organizations. Communication promises to play an important role by highlighting environmental risk.

\section{Communicating Environmental Risk}

Environmental risks are commonplace in rural and urban settings of Africa. Undoubtedly, the risks bring to light a multiplicity of conditions which are harmful and sometimes insurmountable. Bussotti (2014) writes in, "Environment Risk Management and Communication in an African Context: The Case of the Mozal bypass in Mozambique". The writer describes a case involving risk management and how the risk was communicated to stakeholders and the people whose habitat was threatened. Bussotti discusses Mozal, a short form for Mozambique Aluminum. Essentially, Mozal is one of the largest multinational corporations operating in Mozambique.

Not surprising, the national aluminum company is a gigantic entity. It is also manifested in the Mozal Association of Community Development. By virtue of its association, Mozal takes on development initiatives on one hand, and shepherds environmental communication on the other. Today, Mozambique ranks as the world's fifth largest producer of aluminum, amassing wholesome wealth into the country's treasury. In 2010, Mozal decided to construct a "bypass" at its two Fume Treatment Centers.

For two months, the aluminum giant was generously authorized to discharge emissions into the air without using filters, causing harm to human health. Bussotti's writing seeks to understand how the various parties involved acted to prevent, first, the man-created environmental hazard, and second, how Mozal managed and communicated the risk to the populations. The author analyzes the debate on risk communication in Mozambique.

Mozal's management has always ignored the principles of modern communication in relation to environmental risk. Within the corporation, management made choices that favored a "worker elite" capable to absorb the ideas and procedures imposed based on Best Operation Proceedings (BOP). The objective was to inculcate a mentality of prevention stemmed from the 
conviction that, the technology that was used by the modern company would render "zero harm". This incredible explanation created a dichotomy.

There were those in the country who saw Mozal's investment as important and strategic for the future of Mozambique; others saw that the environmental malaise brought about by the "bypass" was particularly serious, compared to the benefits for the local economy. Obviously, a debate with opposing views had ensued, placing the media directly at the center. The daily paper, Noticias, has a history of always portraying Mozal as a national company that greatly contributes to the development of Mozambique. Nevertheless, polemic questions of an ecological nature regarding the bypass have not been suppressed.

Ardent critic and Green Party leader, Guimarãs Mahota, was rarely brave. The politician accused Mozal of perpetuating an "environmental catastrophe", pointing out that the government lacked moral environmental standing, let alone ecological ethics as evidenced by its silence on the matter. Certain voices declared that the government was Mozal's megaphone; other voices decried that the right to access information was systemically denied to citizens in favor of unclear interests. The Compliance Advisory (CAO) Ombudsman, read, "Once more the main obstacle... was the very poor flow of information and the communication of risk adopted by Mozal".

The following shows reportage on the bypass environmental disaster in the Mozambican press:

- Noticiãs ${ }^{8}$ : Portrayed the bypass as a controlled operation, never making it clear that it has arisen from an unpredictable and unpredicted technological accident. The instances when it used a more deserving tone was when it covered the political debates. It presented the opponents as irrational and stopping or slowing down the country's development;

- $O$ País 9 : Presented the environmental risks deriving from the Mozal bypass in a different light. The privately-owned paper associated Mozal's position with that of the Mozambican government. It mocked and ridiculed the weakness of the latter. The paper's headlines were bombastic, as were the editorials;

- The Weekly A Verdade ${ }^{10}$ : Published nineteen articles on the bypass between July 2010 and 9 November 2011. The paper hardly published articles. Instead, it republished stories from other media, and usually with no comments made. Majority of articles were press releases.

\footnotetext{
${ }^{8}$ Noticiãs is a Mozambique newspaper. Available online at http://www.jornalnoticias.co.mz

${ }^{9} \mathrm{O}$ País is a Mozambique newspaper. Available online at http://opais.sapo.mz

${ }^{10}$ A Verdade is a Mozambique newspaper. Available online at http://www.verdade.co.mz
} 


\section{Raison d'Être of Environmental Communication}

There is good and evil on earth. So, too, is there right and wrong. And, then, there is "The Right and the Good", as McEwen (2014) puts it. The author says communication is at the heart of what we humans do in our personal and professional lives. This, says the author, leads humans to reach a better understanding of social practices, institutions and policies that shape the world we live in.

And since communication helps us understand the world, the author goes on, the difference between "The Right and The Good" messages is relevance when it comes to environmental communication. McEwen refers to the concept of what one should do; it is really about persuading someone to change behavior or act in a certain way. Preventing the ruin of mankind's ecosystems is something that involves everyone, including children. To this end, mankind's environmental decision-making is based on what is considered Right and Good.

In keeping with "right and good", humans first lived harmoniously with nature, even when early man lived in caves while hunting and gathering as means of survival. Needless to say, man caused little or no damage or harm to the environment. Waste or pollutants were purely natural, widely spread and easily absorbed. But as human numbers increased, food surpluses were stored or traded for protection or goods; people interacted and societies expended; cultures organized; and populations grew with prosperity. Eventually, a multiplicity of humans overcame resources.

These apparent life-threatening conditions prompted Paul and Anne Ehrlich (1990) to write and publish the book, "The Population Explosion". The book describes how the earth's population grows by 95 million people a year. Consequently, the planet's resources are dwindling rapidly, causing famine, global warming, acid rain and other major problems. The authors elaborate the "immediate action that will lessen the threat of ruin and begin to build a more peaceful, sane and secure world". It is critical that the threat posed by environmental abuse, or neglect to communicate same to the youth, be made a priority.

\section{Youth Relationship with Environmental Communication}

That the Mozambican press provided extensive coverage on a controversial life-threatening environmental issue is not commonplace in Mozambique. In fact, interest in issues about the environment transcends African borders, after all the youth are tomorrow's leaders and the next generation belongs to them. It is not surprising, therefore, that the UN declared 2000-2015 the decade of Education for Sustainable Development. Of significance is that, the international declaration emphasized the need to closely connect environmental communication and the younger generation. To amplify the point, the UN declared 2010 as the International Youth Year, 
which proclaimed the world organization to enhance youth power in tackling current challenges of humankind.

The UN's action was further propelled by the recognition that young people have a dual role in getting environmental messages through the society. On one hand, the youth can act as effective intermediaries, transmitting environmental messages to their families and they represent the adults; and on the other hand, youth are tomorrow's citizens, consumers and workers. EECN Newsflash, in, "Framing environmental communication and youth", calls on teachers and communicators to help children hold a common definition and apply same values to sustainability; underline the idea that action triggers change, instead of deterministic worldview; try to generate a balance between passionate commitment and critical thinking; and to help youth become actioncompetent for sustainable development.

This is consistent with the view that the future will be a different nature and that young people hold the strings of defining it. In Argentina, an interesting initiative is the UN-Habitat Best Practices, namely, "Rosario: The City of Children". The purpose is to connect nature and culture, theory and practice and to integrate children, youngsters and adults in the building of a new ecological thought.

The online publication argues that, engaging youth and encouraging them to participate in projects is a good way of including them in their community and in raising their awareness on environmental issues. Another initiative was set up in a rural area of Kenya. It began with organizing soccer and volleyball leagues for the local youth, and then linking them to waste prevention using a very innovative strategy. The Kenyan initiative awarded league points for each garbage cleanup project completed by a team.

The success of the above youth initiatives underlines the importance of integrating various activities targeted at stakeholders and at different geographical levels. The authors believe the youth can be educated and enlightened about the importance of the environment, hence strengthening the need for environmental communication. This includes multiple youth-friendly principles that reinforce each other; involve youth directly in environmental improvement activities; use broad-based approaches such as population groups, policy domains and program area; involve local communities; include a variety of stakeholders rather a single organization or government agency; and to spread and expand projects.

Speaking about youth, Andrew Revkin ${ }^{11}$, in a blog, "Environmental Communication in 2015", discusses communication and the environment with journalism and science students at Ohio University. The writer had been invited to speak to Professor Bernard Debatin's class on the topic. The writer and learners examined the merits and limitations of blogging, which can be an excellent medium for ideas and observations; it can also expose general audiences to issues and ideas they might never otherwise consider. More

11 Revkin, A. (2015, May 27). Environmental Communication in 2015 [Blog post]. Dot Earth. Retrieved from https://nyti.ms/2TancLu. 
importantly, they talked about the environment and media challenges in a modern world and to immerse in necessary reportage.

Mindful of the student audience, Andrew Revkin asked the question: What is your vision of how the public will track environmental issues and developments in five years? Here is a sample of the answers:

- Sarah: Over the next five years, I suspect grassroots and community organizations concerned with environmental issue will become more sophisticated in their ability to spread their message. Whether through social network sites or through the publication of their own magazine, more and more people will get their information from those invested in and directly working on the issues. This has the potential to destabilize any centralized distribution of information and instead develop a stronger web distribution, where each locality is linked to a larger system;

- Kabercik: We often walk around with cell phones or iPads or and headphones. Our ways of receiving information are becoming hightech, and the same applies to how we receive information about environmental issues;

- Susie: One component of environmental coverage that suffer is investigative journalism. Investigative stories require an incredible amount of time and money that bloggers and citizen journalists may not be able to afford. Will alternatives [media] take on environmental topics; and

- Alaquist: Of course, we cannot forget Google. I want to start with communications policy-making. The system desperately needs reconfiguration with the environment and Internet at the center. Let's tax Google and Microsoft to ump some money into environmental communication. I'd love to see public libraries as part of a revitalized public sphere where we come together to talk about environmental issues. We also need mobile technology to connect with people digitally.

Africa Renewal reports on the environment, including the work of Greenpeace International. The publication interviewed Kumi Naidoo of South Africa known for fighting for the environment, development and people's empowerment (africarenewal/taxanomy/term/7). "Economic growth is not sustainable without social and environmental justice", concedes Kumi Naidoo. "We need to adopt a sustainable path for our future, and for the future of our planet and our continent".

The critic admits that the 2012 Rio summit ended the false dichotomy between the environment on one hand, and development on the other. To be credible, the writer adds, Rio 2020 must support an energy revolution based on renewable energy and energy efficiency. In other words, government and businesses must commit to zero deforestation by 2020. "At Rio governments 
must listen to the people, not the polluters, otherwise they are bound to fail the world", concludes Kumi Naidoo.

\section{Discussion}

The Africa Environment Information Network (AEIN) published its implementation guidelines in November 2004 on capacity building for access to information and knowledge in support of growth and management of Africa's environmental resources for sustainable development. It is noteworthy to mention that, AEIN intends to strengthen African's information know-how to make intelligent decisions when it relates to the environment. A key objective is to establish essential data on environmental communication through an information management system.

The system is aimed at sharing environmental data and information resources at the institutional level, while providing a framework for integrating, analyzing, synthesizing and reporting at various levels. Specifically, the guidelines target the audience as follows: national data centers involved in the generation of relevant information; environmental information management socialists; personnel responsible for managing AEIN activities; consultants and freelancers; plus, national environmental organizations responsible for identifying environmental themes.

A constructive environmental communication network is aligned with environmental themes to assure efficiency, information management, information systems and information technology. Moreover, the vision is a strategic context which provides orientation and direction; to demonstrate the importance of information as per AEIN's mandate; and to outline information requirements for environmental management and reporting that includes assessment of information sources.

The process of managing information sources, maintaining and auditing information as a strategic asset, is core to managing the environment. A properly conceptualized and well-managed environmental communication unit is responsible for supporting organizational activities; dealing with interrelated components such as hardware; software, disseminating data and information; and facilitating knowledge and information to address environmental issues. Above all, the guidelines are to emphasize information and communication technology to provide necessary mechanisms in implementing information about change in the way Africans relate to the environment.

The Eastern Africa Environmental Network (EAEN) is based in Nairobi, Kenya. Basking in the glow of Africanism, the organization has charted the monumental cause for Africans and their environment. Since its founding in 1990, EAEN has displayed a commitment to maintaining a human-friendly habitat to improve the quality of life and to bring about a sustaining environment. Furthermore, it is the policy of the organization to promote peace and food security with a focus on environmental protection and natural resource conservation. 
EAEN contends that sharing of information, experiences and resources is crucial to socio-economic development and a healthy environment. Accordingly, EAEN has created a communication strategy which features an annual conference on production and dissemination of publications on the environment. The content of the publications is feature stories, commentaries and short stories concentrating on environmental issues. www.eaenetwork.org is part of the communication network. The organization attempts to communicate with opinion leaders and key decision makers as target audience.

Ecologist Vijayalaxmi Kinhal ${ }^{12}$ says the environment is an important issue when society is faced with economic crises, wars and unending social problems. The researcher maintains that the environment is important because Earth is the only home that humans have; it provides air, food water and essential needs. The ecosystem system, too, is humanity's life support. It depends on the well-being of all the species living on earth, usually referred to as the biosphere. The latter encompasses one global ecological system in which all living creatures are interdependent. And amid the one global ecological system are smaller ecosystems such as rainforests, oceans, the desert and tundra.

Of ultimate importance to the environment is that, the ecosystem is composed of living and non-living parts (terrestrial or aquatic). In the book, Valuing Ecosystem Services - Toward Better Environmental Decision-Making (available through The National Academy Press) ${ }^{13}$, the non-living parts are the soil are water, air and nutrients; the livings parts are plants, animals, microorganisms and humans. In a healthy ecosystem, all the chemical elements and nutrients keep circulating in a cycle to support millions of species. It is in this process that a variety of goods and services, all useful to humans, are produced. Hence, the impetus for humans to champion strategies to maintain an invaluable ecosystem and sustainable environment remains paramount.

Workshops that focus on the mutuality that exists between the environment and communication are conducted at various levels. They deal with message conceptualization and dissemination. EAEN's partners are Mali Hai Clubs of Tanzania; Dodoma Environmental Network; Wildlife Clubs of Uganda; Natural Resource Protection Group (Sudan); The East African Wild Life Society; and Resource Management (Somali). Additionally, EAEN publishes a quarterly magazine, Njiwa, disseminated to different audiences and stakeholders on matters pertaining to the environment and communication. Conference proceedings and workshop activities are disseminated, too.

\footnotetext{
12 Kinhal, V. (N.D.). Why Is Our Environment Important? [Online article]. Retrieved from https://bit.ly/2O7nSQU.

$\frac{13}{13}$ Valuing Ecosystem Services - Toward Better Environmental Decision-Making (2005). The National Academies Press. Washington, DC. Retrieved from https://www.nap.edu/read/11139/chapter/1\#xi.
} 


\section{Conclusion}

Ethel Kennedy, writing in, "The Chad Cameroon Oil and Pipeline Project: Putting People and the Environment at Risk" (1999), raises concerns. The writer quotes Archbishop Desmond Tutu, "Africa cannot afford the environmental devastation of such a project. We need to help construct, not to destroy it". The Chad-Cameroon Oil and Pipeline project is bound to exacerbate environmental devastation and will violate human rights. In a bid to bring about environmental communication, Huawei has established branch telecommunication offices in more than 40 African countries. They include sales and services, technical and manufacturing centers. These initiatives have led to the hiring of talented Africans to enter the field of communication and have charged them with disseminating information on environmental protection.

The chief executive officer of Exxon was quoted in the Wall Street Journal on 14 October $1997^{14}$ as "boasting" that poor developing countries cannot afford environmental protection, adding, "If they insist on such measures, foreign investment might go elsewhere". Ethel Kennedy (1999) is bemused because these pronouncements are contrary to poverty alleviation and sustainable development, as they gamble with the lives of Chadians and Cameroonians. Today, South Africa pursues an environmental sustainability policy; the country participated in the 1992 United Nations Conference on Environment and Development (UNCED). In 2009, East Africa nations met in Kigali (Rwanda) to reaffirm their commitment to examine linkages between population and the environment.

It is fair to say that Africa and Africans are not oblivious to existential threats posed by an "unfriendly environment". John Muthee, writing under the title "Serving and growing with Africa: How Huawei enriches life through Communication" (2018), applauds Huawei Technologies for going beyond commercialization to enrich the lives of Africans by providing communications network solutions. John Muthee regrets the prevalence whereby corporate profits have relegated human service to irrelevance, and commends the telecommunications company on "enriching the life of African people with the diversified communication services offered by affiliate telecom companies". The writer notes that Huawei is on a mission to address the economic and geographic imbalance by bridging the digital divide and elevating local telecommunication expertise.

The Stockholm Challenge is entitled "Awareness raising and education about Africa Environmental Justice and Sustainable Development Challenges". Besides addressing concerns embedded in the title, the organization serves a dual purpose. First, it is a tool to communicate to the international community in order to raise awareness about Africa's environmental challenges. Second, it has as a goal to combat poverty by promoting socio-economic development. As

\footnotetext{
${ }^{14}$ http://umich.edu/ snre492/Jones/pipe.htm.
} 
deity would will it, the United Nations Environment Program (UNEP) is headquartered in Nairobi, Kenya.

Exactly five years after statehood and independence, South Africa's Minister of Environmental Affairs and Tourism, Mohammed Valli Moosa, said in 1999 that 20 percent of households, and one-sixth of the global population, lives in poverty. The critic admits that the 2012 Rio summit ended the false dichotomy between the environment on one hand, and development on the other. To be credible, the writer adds, Rio 2020 must support an energy revolution based on renewable energy and energy efficiency. In other words, government and businesses must commit to zero deforestation by 2020 . "At Rio governments must listen to the people, not the polluters, otherwise they are bound to fail the world", concludes Kumi Naidoo. Paul and Anne Ehrlich (1990) wrote and published the book "The Population Explosion". The book describes how the Earth's population is growing by 95 million people a year, thus depleting the planet's resources.

Speaking about youth, Andrew Revkin, in a blog (2015, May 27), "Environmental Communication in 2015", discusses communication and the environment with journalism and science students at Ohio University. The writer had been invited to speak to Professor Bernard Debatin's class on the topic. The writer and learners examined the merits and limitations of blogging, which can be an excellent medium for ideas and observations; it can also expose general audiences to issues and ideas they might never otherwise consider.

\section{References}

Africa Environmental Outlook (AEO), (2013). Retrieved from https://www.unenvironment.org/resources/report/african-environmentoutlook-3-aeo-3-summary-policy-makers

Boykoff, M. T., \& Roberts, J. T. (2007). Media Coverage of Climate Change: Current Trends, Strengths, Weaknesses. United Nations Development Program, Human Development Report: Occasional Paper. Retrieved from https://bit.ly/1ytXa8K.

Bussotti, L. (2014). Environment Risk Management and Communication in an African Context: The Case of the Mozal bypass in Mozambique. Cadernos de Estudos Africanos, 28, 93-118.

Correll, H. (N.D.). Environmental Communication Course Syllabus. Retrieved from https://theieca.org/sites/default/files/syllabi/correll.pdf

Ehrlich, P. R., \& Ehrlich, A. H. (1990). The population explosion. Ecology Law Quarterly, 18(1), 259-263.

Halweil, B. (2007). Still No Free Lunch: Nutrient Levels in US Foods supply eroded by pursuit of high yields. The Organic Center. https://www.organic-

center.org/reportfiles/Yield_Nutrient_Density_Final.pdf. 
Kaya, H. O., Ruffin, F. A., \& Teffo, L. J. (2016). African indigenous languages and environmental communication. Journal of Human Ecology, 53, 185193.

Kennedy, E. (1999). The Chad Cameroon Oil and Pipeline Project: Putting People and the Environment at Risk. Environnemental Defense Fund [US], Association Tchadienne pour la Promotion et la Defense des Droits de l'Homme [Chad], Centre pour l'Environnement et le Developpement [Cameroon].

Kinhal, V. (N.D.). Why Is Our Environment Important? [Online article]. Retrieved from https://bit.ly/2O7nSQU.

McEwen, G. (2014). The right and the good: communicating environmental issues. Earth Common Journal, 4(1), 1-51.

Muthee, J. (2018). Serving and growing with Africa: How Huawei enriches life through Communication. Retrieved from https://bit.ly/2Xt7IG0.

Kamanzi, S. (2009, March 25). https://www.prb.org/rwandaphenetwork/.

Revkin, A. (2015, May 27). Environmental Communication in 2015 [Blog post]. Dot Earth. Retrieved from https://nyti.ms/2TancLu.

UNEP (2017, September 20). Retrieved from https://corporate.discovery.com/discovery-newsroom/un-environment-anddiscovery-communications-partner-to-engage-world-on-environmental-action/.

Valuing Ecosystem Services - Toward Better Environmental Decision-Making (2005). The National Academies Press. Washington, DC. Retrieved from https://www.nap.edu/read/11139/chapter/1\#xi.

Wolfensohn, J. (1999). World Bank Group Approves Support for ChadCameroon Petroleum and Development Project. Press Release No. 2000/395/AFR. Retrieved from https://bit.ly/2CnYPEN. 


\title{
Citizen Journalism in France: Professional Practice and Self-Regulation
}

\begin{abstract}
By Waleed Ali*
In a few years, the media landscape has undergone rapid and unprecedented transformations, due to the significant advancement of Information and Communication Technologies (ICTs), which have greatly influenced the publication and the press. In this context, citizen journalism appeared in the wake of Web 2.0 that gives individuals the opportunity to produce and distribute their own content, as well as allowing them to interact with each other. However, the increasing dependence on citizen journalism at an unprecedented form also highlights the importance of studying this phenomenon in depth. This study aims to identify citizen journalism in France-especially about its implications for journalistic practices, as well as the selfregulation of this phenomenon. The study concludes that, this form of journalism is not professional journalism because they do not have the same objectives. Besides, citizen journalists are not "sources" of information but that they are new filters to the news. Thus, citizen journalism does not pose a threat to professional journalism. However, its collaboration with traditional journalism is a benefit, because it alone is not credible. The study found also that self-regulation would be the real benefit or a compromise to keep the relation between professional and non-professional journalism.
\end{abstract}

Keywords: citizen journalism, practice, self-regulation, user-generated content.

\section{Introduction}

In a few years, the media landscape has undergone rapid and unprecedented transformations, due to the significant advancement of Information and Communication Technologies (ICTs). These have greatly influenced the publication and the press. In this context, the social web appeared in the wake of Web 2.0, "a sociotechnical device characterized by its interactive platforms and new collaborative practices". This new generation of Internet applications and services supports of so-called participatory dimension, which gives individuals the opportunity to produce and distribute their own content, as well as allowing them to interact with each other. Thanks to the Web 2.0 platforms, anyone can now produce and distribute journalistic content; this is called user-generated content.

Thus, this privilege no longer belongs to the information professionals alone. This phenomenon obviously affected journalism, whose practice suddenly seemed to open up to the greatest number. Authors have even claimed that "every citizen is a potential journalist" (Rebillard, 2007, p. 16) and that "everyone capable of producing news" (Gillmor, 2004). These amateur information initiatives that have taken off with the emergence of the Internet are described as citizen journalism, participatory journalism or citizen reporter.

*Lecturer, Department of Media, Tanta University, Egypt \& Scientific Researcher, ENSSIB de Lyon, France. 
There is no doubt that we are living in the realm of new media or the "fifth estate" (Newman 2012, p. 15), which has enabled people to raise their voice on what they feel needs attention. These people are, thus, termed as citizen journalists (Rabia, 2017, p. 55). Since 2005, France has been experiencing new forms of online journalism, described as "participative", that is to say offering nonjournalists internet users the opportunity to participate in the development of information, in various forms. The AgoraVox site was launched in 2005. The starting point of the founders is to consider that, thanks to the effective democratization of multimedia and ICTs, "every citizen can potentially become a "reporter" capable of identifying and proposing high value-added information". AgoraVox's editorial policy is "to make freely available to its readers, thematic information as far as possible, unpublished, and detected by the citizens".

Indeed, the issue of citizen journalism has been the subject of several kinds of research, particularly in France, which have made it possible to trace the contours of this object, to better understand the stakes it raises and to identify the main issues. Citizen journalism is an important topic for investigation today because of the difficult times that many newspapers are facing, which may be one of the things that lead newspapers to their survival in tough economic times (Fico et al., 2013). Citizen journalism can also serve as a potential way to "revitalize public debate" (Larsson, 2014, p. 78) in a time of loss of the credibility and objectivity of traditional media (Carr, Barnidge, Byung, and Tsang, 2014).

Citizen journalism is a soft paradigm that spreads like wildfire among active Internet users. The weakening of the traditional boundaries between sources, media and the public reactivates the imaginary of a disintermediated communication (Olivier, 2007), where editorial contents circulate outside the traditional media circuits. Also known as basic journalism, network journalism, participatory journalism, hyper-local journalism, bottom-up journalism, distributed journalism.

Based on the discussion above, we can say that citizen journalism is a concept based on the active participation of readers, viewers, and listeners in the process of collecting, selecting, analyzing and disseminating news and information. However, citizen journalism through its existence raises issues related to its practice and role in society and the impact it might have on traditional journalism besides the issues of self-regulation

\section{Literature Review}

In this section, we will work to build our theoretical framework that is to conceptualize our problematic by defining the main concepts used in this research and arranging them.

\section{Citizen Journalism: From Public to Individualism}

Definition of citizen journalism. The emergence of a new generation of websites underpinning a bottom-up innovation dynamic (Cardon \& Delaunay- 
Teterel, 2006) has helped to found new areas of communication, information, and journalism. New editorial and sociotechnical practices then appeared, like the one that will study here: citizen journalism. In the past years, journalists and researchers have defined citizen journalism countless times. Deuze described participatory journalism as "any kind of new work at the hands of professionals and amateurs, of journalists and citizens" (Deuze, Bruns, and Neuberger, 2007, p. 323). More recently, readers of newspapers were given the opportunity to write and publish their own original material as citizen journalists through letters to the editor (Allan, 2007). As technology has advanced, so have the ways that citizen journalists can make contributions via the web (Braun \& Gillespie, 2011). Now, a citizen journalist can be someone who contributes content to blogs, takes photos and shares them online (Goode, 2009).

Indeed, we found that authors and researchers used many names to talk about the practices inherent to "amateur participation in news sites, understood as the production, by "non-journalists" of content related to the news" (Pignard \& Noblet, 2009, p. 1). In addition to the term citizen journalism, others are used in both French and English, such as participatory journalism, amateur journalism, ordinary journalism, citizen-reporter, citizen journalism, participatory or participative journalism, people's journalism, citizen reporter, etc. However, several authors use different appellations without distinction, without favoring one

The expression citizen journalism, while widely used, seems to be primarily assumed by leading essayists who have defended the subject, such as De Rosnay in France (2006) and Gillmor in the United States (2004). Although some researchers consider it objectionable, including Ruellan who believes that this "suitcase" "assigns a very heavy role for the media or individuals - why these and not others - monopolize" (Ruellan, 2007, p. 3). From this perspective, Rebillard defines what he calls participatory journalism as "the intervention of nonprofessionals in journalism in the production and dissemination of current news on the Internet" (Rebillard, 2008, p. 354). This definition is similar to Ruellan's (2007):

"Netizens, non-professionals in journalism, contributes directly to the production of news. They search for data, analyze it and put it online, with or without the help of professionals". (p. 2)

Radsch (2013) defines the essence of citizen journalism as "an alternative and activist form of newsgathering and reporting that functions outside the mainstream media institutions often as the repose to the shortcoming in the professional journalistic field". One can, of course, wonder if these "non-professionals of the journalism" really adopt a journalistic approach which makes them contribute "directly to the production of the new information". In his book on the social history of digital technologies, Mondoux prefers to use the term citizen-reporter and describes the phenomenon by giving citizens a more modest role. Thus, since 2003-2004, the notion of citizen-reporter is gradually being imposed, that is to say, those individuals freed from the institutional media (the fourth power) and "free" to report the "real" facts as witnesses direct. The public is invited to submit their 
comments, images, and video clips and thus become part of traditional journalistic production (Mondoux, 2011, p. 189).

Mark Glaser ${ }^{15}$ thinks that "citizen journalism allows people without journalism training to use contemporary communication tools and Internet broadcasting capabilities to create, improve or verify information". According to Jay Rosen, citizen journalists are "the people who made up the old audience", who was at the end of a one-way media chain. Today we are no longer in this situation; the old audience has simply become more real, more capable and less predictable. Joel de Rosnay and Carlo de Revelli define the citizen journalism or "participative" as a concept present on spaces of diffusion which publish and centralize information coming from individuals, sorts of testimony inform articles, pictures, or videos. This concept is not part of the criticism of the media or the information they transmit. It is characterized by "a notion of responsibility and inscription in the life of the city, without a predefined or imposed political orientation".

According to Richard Patrosso ${ }^{16}$, citizen journalism is a fifth power that must control the work of professional journalism to denounce corruptions and restore the truth if it contains errors. It is a voluntary act that does not have the same obligations as a professional journalist. Neutrality is not required since the citizen journalist has to denounce. In addition, he must seek the maximum visibility and therefore get out of the territory of his blog to be part of a citizen newspaper with a large audience.

Typology of citizen journalism. Lasica (2003) classified citizen journalism into the following categories: 1) Participation of the readers (such as comments on a site, a blog; photos or videos captured during an event; or local news written by a member of a community), 2) Independent news and information Websites (for example, "consumer reports" in the United States or "60 million consumers" in France, 3) Participatory news sites (like OhmyNews in Korea or AgoraVox in France, which citizen-reporters contribute a significant amount of material), 4) Collaborative media based on contributors (such as Slashdot in America and Rue89 in France), 5) Personal broadcast sites (podcasts, web radio), and 6) Other kinds of "thin media" (mailing lists, email newsletters).

Cheynel and Noblet (2009) provide a good classification of the different types of sites hosting amateur participation in the journalistic field. We present a summary of these sites below.

1) Sites out of journalistic-media field. First sites to have systematically and regularly appealed to amateur contributions. Common point: not being worn by mainstream media companies. They also include video news exchange platforms such as Citizen News launched by YouTube.

2) Sites belonging to the media-journalism field. Amateur participation appears as a complement to content produced by professionals. We find in this category the sites:

\footnotetext{
${ }^{15}$ Journalist specialized in Internet and new communication technologies issues. He writes for the Los Angeles Times, CNET, HotWired, The New York Times.

${ }^{16}$ Philosopher and editor in agoravox.com
} 
- Traditional media sites that use amateur contributions, whether in the form of chats, jokes, comments, sending photos/videos, etc.

- Sites of pure players (sites that are exclusively found on the net, whose main positioning is based on a co-presence of content produced by journalists and amateurs); as "Rue89".

- Sites launched by media groups but demarcated from the main title (intermediate form), as is the case for Le Monde.

AgoraVox: The first European initiative of citizen journalism. AgoraVox is defined as "the first European initiative of citizen journalism". This site was created by Joël de Rosnay and Carlo de Revelli in 2005. The aim is to allow all information sensors to express themselves freely. According to the creators, as it is easily possible to be the witness of an event (thanks to the digital cameras and the camcorders), it must be as simple to be able to diffuse the information which results from it. That is why AgoraVox is completely free for writers. The site is based on "grassroots journalism": the idea that news does not come exclusively from the top (the media) but also from readers. Thus, this site has a motto that says "Every citizen is a Reporter".

Figure 1. Screen Shot of AgoraVox Website

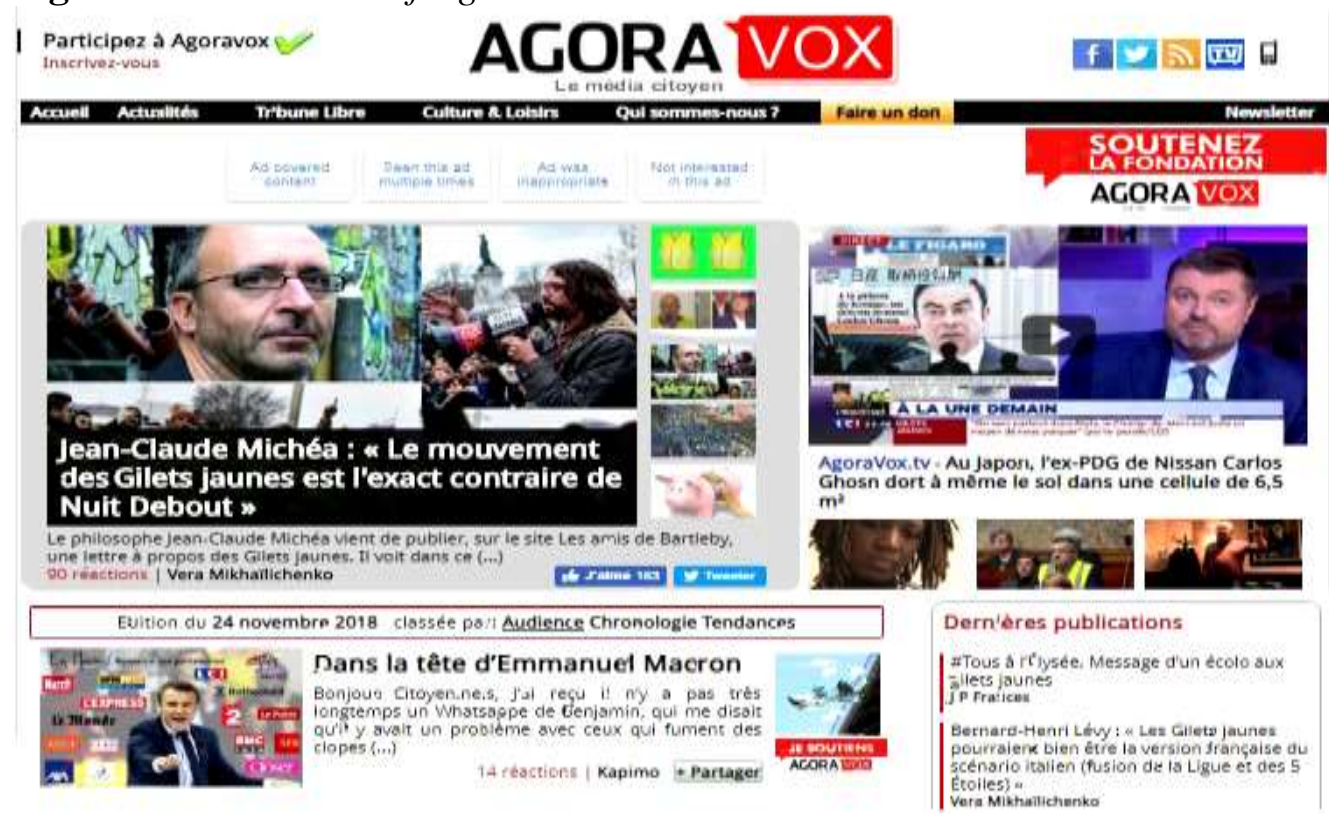

Source: https://www.agoravox.fr/.

AgoraVox wants to be the platform of the information but corresponds more to a collaborative blog where each editor delivers its analysis of events often followed in the professional press. Reading the site, it brings new insights into facts and events. It makes possible to leave the discourse of traditional journalism by taking problems from different angles. The site also allows opening the debate through the use of comments. Unfortunately, the large attendance of the site makes 
very quickly the follow-up comments. There is also a filtering of articles by Internet users themselves who can vote for or against an article based on his interest. This system does not make it possible to put in one article according to the number of votes (in the manner of Digg) but gives only an indication to the readers of the quality of the article (Figure 1).

In conclusion, AgoraVox looks more like a collaborative blog. Its main missions are information to the public and support for freedom of expression. Finally, it is also interesting to see how all the other growth indicators (number of articles published, editors, commentaries posted and moderators) have constantly progressed almost doubling all between 2009 and 2017 (Table 1).

Table 1. Growth Indicators between 2009 and 2017

\begin{tabular}{|l|c|c|}
\hline & December 2009 & October 2017 \\
\hline Published Article & 60.000 & 113.988 \\
\hline Editors & 50.000 & 90.467 \\
\hline Comments posted & 1.300 .000 & 3.319 .421 \\
\hline Moderators & 1.500 & 3.262 \\
\hline
\end{tabular}

Source: https://www.agoravox.fr/.

\section{Journalistic Practice in the Digital Age}

This study tries to look at the practice of Citizen Journalism, thus, it is important to understand how it has been practiced. It is also important to review the literature on citizen journalism around the globe, and citizen journalism in France. This is reviewed below. Our review of the literature has shown us that there are many scientific articles on the changes made by the Internet on journalistic practices. Since the end of the 1990s, many studies have focused in particular on the implications of ICTs for the journalistic profession. Le Cam and Estienne studied the practices of these "new information workers online", and also how they represent themselves and how their emergence weakens the boundaries between professionals and amateurs (Le Cam, 2006, Estienne, 2007). In this context, some researchers have analyzed the major issues raised by citizen journalism for the journalistic profession (Tredan 2007). The subject of information blogs is also widely discussed in the literature, whether it is to establish their portrait and the questions they raise in relation to journalistic identity (Le Cam, 2006) or to postpone in question the democratic potentialities often attributed to them (Pledel, 2006). Some researchers also sought to explain the social origins of citizen journalism by linking it to a crisis in the media (Tredan, 2007) and placing it in the continuity of public journalism (Le Cam, 2006; Ruellan, 2007; Tetu, 2008). Other researchers focused on contributors to determine who they were, and what their skills and motivations were (Aubert 2011; Tredan 2007).

It should also be noted that several sites exclusively dedicated to citizen journalism have been the subject of a detailed study, notably OhMyNews, AgoraVox and Rue 89 etc. (Aubert, 2011). Some researchers have concluded that the quality of amateur contributions often leaves something to be desired. They 
also noted that certain sites that host these practices, traditional media or pure players; we are now focusing more on professional supervision of citizens (Pignard \& Noblet 2008; Aubert 2011).

\section{Objectives}

In the age of social networks, public participation seems to be a real golden age on the Internet. By making the participatory dimension possible, Web 2.0 technologies have given rise to amateur information initiatives, better known as citizen journalism. Indeed, the citizen journalism topic is important, especially in the area of democratic communities, because of the changing ways that news and information are shared within these communities.

This research aims to identify this phenomenon, its role in society, and its implications for journalistic practices, as well as the upheavals caused by what is called the "digital revolution".

\section{Methodology}

The increasing dependence on citizen journalism at an unprecedented form also highlights the importance of studying this phenomenon. Consequently, our study presents a practical support, by abandoning traditional methods and adopts new methods. In this respect, this study based on a systematic review of the literature, that differs from a narrative review. While a narrative review provides an overview of the content available on a given topic, a systematic review is more narrowly focused and seeks to assemble, critically appraise or evaluate and synthesize the results of primary studies in an integrative approach.

\section{Findings}

\section{Axes of Citizen Journalism Practices}

The practices of citizen journalism can be summarized in three main axes: (1) in its relations with traditional media/journalism, 2) its information and communication technologies (ICTs), 3) and the democratic society. Besides, we will also focus on the benefits that citizen journalism offer in relation to each of these axes.

\section{Axis of Media/traditional Journalism}

The crisis of public confidence. Of course, technological changes are not the only ones that have had an impact on the evolution of journalism. The social context also plays a determining role. According to several researchers and observers, the so-called traditional media and journalism are currently going through what appears to be a crisis of public trust. After having experienced in many countries a "good times" in the 1970s and 1980s, journalism seems to have 
plunged since the beginning of the 1990s into a period of questioning because of important socio-political and economic changes (Neveu, 2009, p. 93).

Although the emergence of Web 2.0 is not the starting point for this role that media consumers are actively demanding, the potential of the tool has nevertheless accompanied this phenomenon of appropriation, which is reflected in the emergence of the term "Citizen journalism" claimed by many Internet users (Aubert, 2011, p. 99). Aubert believes that "journalism and its social function have been put to the test for some years by the evolution of the relationship with the information of the users" (p. 99). Tredan shares this conviction that citizen journalism is born as much from this moral crisis of the media as from the possibilities offered by the Internet.

"'Citizen Journalism' is part of the particular context of the rise of self-publication and the perception of a moral crisis in the mass media. The imagination of the Internet (Flichy, 2001) has produced tools aimed at democratizing the publication and distribution of information". (Tredan, 2007, p. 117)

Advantages of citizen journalism. Citizen media is presented as an interesting alternative to traditional media. Such a conception is based on the belief that the citizen media would have at least three advantages over traditional media, namely:

- Bridging the information gap. Citizen Journalism sites claim that the information provided by citizens is considered valid and worth publishing. They fill an information gap because the traditional media cannot cover everything, whether out of disinterest (especially for local news) or simply because they cannot afford it.

- Independence (less bias and censorship). The citizen journalism sites claim that offer information that differs from that offered by traditional media. Their emphasis on this point obviously reflects their perception that they are currently experiencing a crisis of confidence as they are suspected of being increasingly subject to the dominant powers, be they political or economic. In this context, they insist that they are more independent, freer and that the information they offer is unbiased. They believe that the editorial staff of the traditional media does not hesitate to censor the comments of journalists, which is not the case in the model of citizen journalism.

- Flexibility. Some sites such as AgoraVox also highlight the fact that the model of citizen journalism is more flexible, that it does not include the characteristic filters of larger organizations and that it, therefore, presents fewer constraints for the citizen reporter. In addition, the fact that more people have the opportunity to broadcast news allows sites to potentially have greater access to different contributor skills. It is implied that citizens are often better informed or have more expertise than journalists in certain fields. 
Axis of information and communication technologies (ICTs). In this axis, we highlight the advantages that Information and Communication Technologies (ICTs) bring to citizen journalism, which gives it an advantage over traditional media/journalism.

New media model. With technological advances and the advent of so-called Web 2.0 or Social Web, which creates a real mass phenomenon (Mondoux, 2011, p. 172), the phenomenon of citizen journalism grows, while individuals have the opportunity to interact with others, produce and distribute content. In this form of journalism, the message can be edited stored and reproduced by anyone at any time, making the position of the receiving person more active and involved. Bowman and Willis (2003) describe citizen journalism as a bottom-up phenomenon in which there is little or no editorial oversight as shown in Figure 2.

Figure 2. Traditional Media vs. Participatory Media
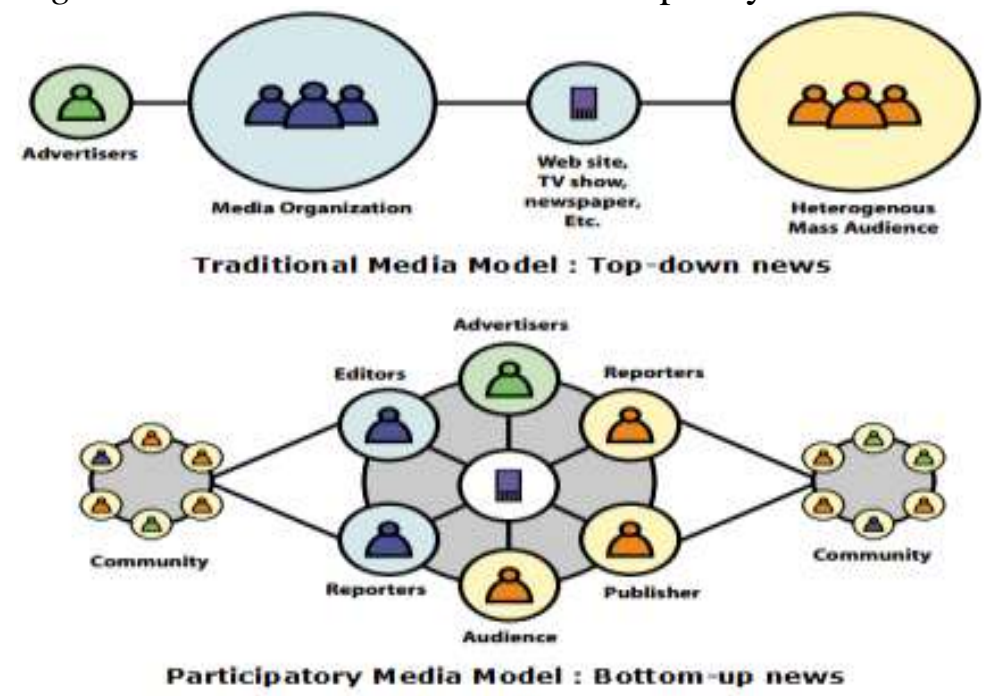

Source: Bowman and Willis (2003).

"While traditional news media have delivered information through a topdown, centralized model with journalists functioning as gatekeepers of information, online news media present greater opportunities for control and ownership as users assume more active roles in their news consumption experiences". (Deborah, 2008, p. 659)

The advent of new technologies is an integral part of media development. The history of communications has been shaped by the arrival of multiple technical inventions designed to enable, facilitate, extend, and even accelerate the spread of messages between individuals. Citizens now had a plurality of media that allowed them to confront the information that was offered to them "(Nobre-Correia, 2006, p. 16). By offering the opportunity to process information in real time, these technologies have led the journalist to change his practices and ways of doing things in order to deal with these new technical modalities.

In the field of journalism, the impact of the arrival of the Internet is multiple: for example, the influence of the Internet on the practices of traditional journalists 
and the emergence of "information workers online" (Estienne, 2007, p. 109), be it the journalists who feed the news sites of the dailies or the media present online or the citizens who launch their own blogs, professional journalists or amateurs wishing to express their opinion and to make their voice heard. As for the work of the journalist, he will have to adapt to the rapid pace of the production of the continuous information characteristic of the Web and be able to deploy simultaneously on different platforms.

\section{Advantages of Citizen Journalism}

- Network interconnection and strength of collaboration. The rise of Information and Communication Technologies (ICTs) has made it possible to connect people in a network. Collaboration made possible by technologies is seen as an advantage, if not a real strength, that can counteract traditional media, which is good for the democratic society. This phenomenon is described as a process of collective intelligence. The words power or power is also often used when referring to the power of the gathering of citizens.

- The speed of diffusion. Interconnected network members and increased access to technology allow citizen journalism sites to benefit from the presence of their members in the field. By giving citizens the opportunity to easily disseminate content, ICTs (Internet and mobile phones) allow them to report on the events they witness on the ground (in short, the "real"). This is seen as a definite advantage as more news can be reported to them from around the world. They invite users to fulfill this role of witness. This idea goes hand in hand with the rapidity of the diffusion that Information and Communication Technologies allow.

Axis of the democratic society. Citizen journalism is allowing increased participation of citizens in public debate. From this perspective, we discuss the relations between this new form of journalism and democratic society. First, we stress the democratic potential of ICTs and then discuss the benefits of citizen journalism for the democratic society.

Democratic potential of ICTs. Citizen journalism sites are more inclined to discuss the democratic potential of ICTs, the speech of AgoraVox, goes in this direction as well. The rise of the Internet is seen as a tool that gives real power to the citizen and allows them to better exercise this role in society.

\section{Advantages of Citizen Journalism}

- The platform of expression. Indeed, citizen journalism helps the public to express their opinion and to tell their story as they have lived. The huge number of blogs, Twitter accounts, Facebook and YouTube that flourish daily on the Internet serve as an example for this claim. With this type of journalism, one can notice that there is a variety of sources 
of information, such as bloggers, eyewitnesses and members of the public to write articles about their stories, they are also given the opportunity to speak for themselves and to give an alternative version of the facts, a version often different from that of the so-called international media and sometimes of those of the governments. The citizen journalism site (AgoraVox) is a platform where any citizen can express himself and make his voice heard. This is seen as a major advantage for the democratic society, with the understanding that if more people speak, democracy will be better. The citizen can make a difference; some even feel it is his duty to speak out.

- The multiplicity of points of view. By offering people the opportunity to speak, citizen journalism offers the democratic society a certain advantage because of the multiplicity of points of view that emanate from it. The diversity of voices and opinions is seen as a vital element of democracy, and a better understanding of the world.

- Educate and inform the people. The phenomenon of citizen journalism is present in the lives of citizens as a means of education and information. For example, citizen journalism has played an important role in educating and informing the population and the outside world of the so-called Arab Spring events, where foreign media have been banned from covering events. Indeed, users of blogs, Twitter, Facebook, YouTube, and other social networks have been elements of information leakage for an Arab world as tightly closed as during its political upheavals and disturbances and mass demonstrations. Members of the public, via the Internet, organized rallies and mobilized resources that led to the fall of political figures including Presidents Hosni Mubarak, Mohammed Morsi of Egypt and Colonel Muammar Gaddafi of Libya. Through these examples, citizen journalism has shown its need to be, its relevance in today's society and the important role it plays in informing and educating the population.

\section{Responsibility: The Missing Link in Citizen Journalism}

In the context of changing media landscape due to the significant advancement of ICTs, the issue of the practice of journalism recently has become the focus of considerable interest and attention. Newly, the practice of journalism had moved from professional to the citizen, where content can be published without passing through a single journalistic filter where assessments can be made about creditability, context, relevance (Fielder, 2009, p. 216). In this context, Ward (2011) defined change in journalism practice as the switch from the professional approach of "filter, and then publish", to the "publish, and then filter" even if this means "uncertainty about its source or accuracy" (Ward, 2011, p. 213).

Indeed, due to the lack of responsibility of digital media reporters, these tools can lead to exacerbating acts of violence, or purposefully used to threaten or terrorize particularly in countries where democratic processes are limited. For example, in 2014, members of the Islamic State purposefully filmed scripted 
footage depicting the beheading of captives. From this perspective, the lack of responsibility is the predominant issue or the missing link in the practice of citizen journalism. Steven Ward notes, that the method of citizen journalism is formed of "a participatory model of democracy which is libertarian in spirit" that cannot compete in effectiveness with professional journalism that is based on "objective news reporting and well-informed analysis" (Ward, 2011, p. 214). Journalism accountability can be secured only by "laws and regulations, markets, public, or professionals" (Ananny \& Kreiss, 2011, p. 324), and citizen journalism cannot be effectively monitored by any of these processes. This is due to the nature of the open online environment that allows anyone to publish any content at any time, besides individual anonymity.

In sum, citizen journalism cannot be effectively monitored by laws and regulations. This is due to the anonymity, as well as an "open environment" that allows anyone to publish any content "might be inaccurate" any time, in order to mislead news consumers.

\section{Regulation of Citizen Journalism}

The digital age has led many researchers to requisition the profession of journalist and its organization, even to consider "rethinking" because of its "structural transformations" (Peters \& Broersma, 2013). In this context, there are many studies announced the complete transformation of news media and/or journalism and even the death of the paid press in favor of renewed information, online, free and participative.

Regulation of newsrooms. Jane Singer studied journalism in terms of challenges to the notion of journalistic professionalism (Singer, 2003), or "resocialization of journalists writing in convergence editorials" (Singer, 2004). Mark Deuze (2004, 2005), revisited the "professional identity and ideology of journalists". Florence Le Cam (2005) studied the reconfigurations of identity at work among Quebec journalists struggling to redefine their identity in the digital age, with the advent of versatility, multimedia skills, a temporality of work accelerated and called into question the meaning of collective work. Cavelier Croissant (2002) exposes the dissociation, during the appropriation of the Internet by the press editors, between the economic concerns and the level of reflection on the renewal of the editorial model.

In France, many researchers study precisely the organizational transformations from the sociological or economic perspective (Charon, 2010; Charon \& Le Floch, 2011; Dupuy, 2013). Attias (2007) emphasizes the emergence of multi-media writing, often in logic of pooling costs. The reorganizations can range from the complete merger of newsrooms with redesigned rubrics to the recreation of editorial dedicated to mobile apps, with the aim of becoming editorials "web first", the paper edition coming after. Other works scrutinize managerial practices in newsrooms, recomposed to adapt to digital (Carbonnel \& Mercier, 2011; Charbonneaux \& Le Cam, 2012). Stéphane Cabrolié has meanwhile conducted a monograph of the site LeParisien.fr to study the "recomposition" of a digital copy 
(Cabrolié 2009, 2010), while Datchary has studied the "loosening of production formats" at Mediapart (Datchary, 2010).

Many foreign works offer monographs or ethnographies of these organizational changes in editorials. For example, in his study about the identity of contemporary journalists, Le Cam seeks to identify some of the peculiarities that characterize online journalists and begin to establish an identity (Charbonneaux \& Le Cam, 2012, p. 62). On the other hand, the very notion of professionalism was debated in the light of developments in the journalistic profession (Aldridge \& Evetts, 2003) because "the progressive invention of integrated editorial teams accompanies a diversification, more important roles" (Degand \& Grevisse, 2012, p. 33). We can, therefore, witnessing a change in the journalistic paradigm (Brin et al., 2004) with dialectic between "destructuring and restructuring" (Demers, Charron, and de Bonville, 2007).

Schudson and Downie (2009) referring to "the reconstruction of American journalism". Sturgis (2012) dares to ask, "Are traditional media dead?", Continuing in the subtitle: "Can journalism survive in the digital world?" However, Allan points out the emergence of a true "ecology of online information", revealing "a climate where seemingly disparate initiatives can begin to consolidate into viable journalistic forms, practices, and epistemologies" (Allan, 2013, p. 154). Based on our discussion above, citizens now play an important role in the production of news, thus this new form of journalism has created new approaches in newsrooms, whatever it is labeled citizen journalism, participatory journalism, engagement, etc. (Melissa, 2017, p. 140).

Source selection. The publications of citizen journalists must also assimilate certain principles in order to be credible. It is not possible to impose the same constraints as professional journalists, but elements of regulation or self-regulation are essential. Natural self-regulation comes from the participatory nature of the web. When disseminated information is false, it generates comments that restore the truth or at least initiate debate. These comments help the reader more clearly perceive the goals of the writer. Internet users must also internalize some basic principles of the selection of information on the Internet. For example, we must first look for the author's qualification in relation to the subject treated. Other indicators can give details of the credibility, such as the number of links pointing to the concerned site. If the user sees through his other readings that the site is often cited in reference, it will receive more attention than if you never expect to talk about it.

\section{Conclusion}

\section{Citizen Journalists: New Filters for News}

First of all, this form of journalism cannot be considered professional journalism because they do not have the same objectives. A traditional journalist must put in perspective while respecting the maximum neutrality while the citizen can express himself freely by delivering his opinions. Readers submit to citizens' 
reflections on a voluntary basis and with full knowledge of the facts. On the contrary, the act of buying a newspaper, or the consumption of any other traditional media, implies the existence of a moral contract between the reader and the journalist.

Indeed, citizen journalism has seen its emergence thanks to the development of new technologies and the ease of publication of information on the internet. Yet this still requires some skills that are not yet available to all. This is why the articles on the Internet are mostly the work of people with computer skills. The citizen journalist like other bloggers, he writes to be read and be recognized by his peers. For this, he broadcasts his articles on participatory newspapers in order to benefit from a large audience. His work differs from that of the professional journalist. It is a form of press review with a thorough analysis and perspective, which will be the real added value of these articles. On the other hand, the citizen journalist writes outside the traditional media sphere, implying that he does not suffer the same pressures and can, therefore, afford to give a personal opinion. However, the reader of this new type of press must have the perpetually alert mind to avoid manipulation and always have mistrust vis-à-vis articles that cannot benefit from the credibility of a major newspaper or a known signature.

Despite the acceleration of information, journalistic competence remains necessary: cross-checking, verifying, synthesizing, analyzing information is a profession. The new channels cannot replace the journalist expertise. Moreover, despite the growth of citizen journalism, the audience of traditional newspaper sites is not weakening. This shows that citizen journalists are not "sources" of information but that they are new filters to the news.

\section{Self-Regulation "Real Added Value"}

Self-regulation refers to the coordination of societal interests according to a common purpose, which involves (at least potentially) importance for the common good (Collin 2016). This definition also presupposes that this coordination presents, at the institutional level, a certain degree of consolidation and sustainability. Self-regulation is not censorship or even self-censorship (Berleur \& Poullet, 2002). Self-regulation of citizen journalism aims to establish minimum principles of ethics, respect for human rights, values, the accuracy of the information provided, etc., while fully preserving the editorial freedom of the subjects and opinions expressed. There is no doubt that, Freedom of expression is certainly one of the founding tenets of the Internet, but we have to take into consideration that self-regulation would be the real added value or a compromise to keep the relation between professional and non-professional journalism.

\section{Citizen Journalism vs. Traditional Media: Vertical Relationship}

In the context of changes in traditional media and journalism (technological and moral), citizen journalism is a phenomenon that they cannot ignore. Francophone websites believe that it can offer an alternative to traditional journalism. However, AgoraVox considers desirable collaboration between the 
two types of journalism, what he puts forward in his model of investigative journalism mixing know-how and supervision of the professionals with the strength of the number of the amateurs. Although some professional journalists criticize citizen journalism, it is nevertheless important to note that both types of journalism have a collaborative relationship that can be described as vertical. Their relationship can be referred to as vertical because the information starts from the bottom, that is to say, that the information goes from the citizen journalist to the professional journalists even if they depend on the first ones to enrich their stories like this. For example, the bombing that took place at the Boston Marathon in 2013. The professional journalists heavily based their information on the stories of people who are not journalists and who were on the scene and who published stories about their Twitter and or Facebook accounts. It was people who were contacted by the continuous news channels playing for the occasion the role of a correspondent at the disaster scene. Another example of their collaboration is found in the creation of TV and radio programs, websites, blogs, Facebook accounts, Twitter accounts and YouTube by the mainstream media to allow people from around the world to contribute photos and videos of news last hour. In this respect, the traditional media like CNN, BBC, and France 24, respectively created I-Report, Your News, to gather information from the public. This highlights the importance of collaboration between professional journalism and citizen journalism.

\section{Professional Standards and Code of Ethics}

Despite the existing collaboration between traditional journalism and citizen journalism, the latter is a threat to the profession. Journalism, like all others, is subject to professional standards and code of ethics and is governed by laws. Anyone aspiring to practice it must undergo training, but this is, unfortunately, not often the case for journalists of citizen journalism. Just as it takes years of training and practice to become a doctor, it is just as much as it takes years of training to become a journalist. Being able to make good pictures, a beautiful video and know how to tell the story does not make someone a journalist but an eyewitness who tells a fact. The journalist is one who respects the rules and laws of the profession even when taking photos that involve the rule of privacy of the subjects of the story. Besides, by treating subjects, the professional journalist respects certain elements like the private life and the anonymity of the subject, which would not respect necessarily from the citizen journalist, and this tarnishes the image of journalism and puts the profession to bad use. In sum, we can say that citizen journalism involves the active participation of citizens in the collection of news and reporting events. On the other hand, it is necessary to emphasize its importance. Citizen journalism plays the multiple roles of denouncing corruption, encouraging accountability, documenting abuse of power while offering alternative views of local and international news. However, its collaboration with traditional journalism is an added value, because it alone is not credible. 


\section{References}

Aldridge, M., \& Evetts J. (2003). Rethinking the Concept of Professionalism: The Case of Journalism. British Journal of Sociology, 54(4), 547-564.

Allan, S. (2007). Citizen Journalism and the Rise of "Mass Self-communication": Reporting the London Bombings. Global Media Journal, Australian Edition, 1(1), 120.

Allan, S. (2013). The Emerging Ecology of Online News. In F. Lee, L. Leung, J. Qiu, D. Chu (Ed.), Frontiers in new media research (pp. 153-172). New York: Routledge.

Ananny, M., \& Kreiss, D. (2011). A New Contract for the Press: Copyright, Public Domain Journalism, and Self-Governance in a Digital Age. Critical Studies in Media Communication, 28(4), 314-333.

Attias, D. (2007). L'impact d'Internet sur l'économie de la Presse: Quel Chemin vers la profitabilité? (Internet Impact on Press Economics: Which Path to Profitability?). $\mathrm{PhD}$ Thesis in Economics, University of Paris, France.

Aubert, A. (2011). Le participatif perçu par les professionnels du journalisme: état des lieux (The participative perceived by the professionals of the journalism: state of the places). Les Cahiers du Journalisme, 22/23, 42-55.

Berleur, J., \& Poullet, Y. (2002). Réguler Internet (Regulate the Internet). Études, 11(397), 463- 75.

Bowman, S., \& Willis, C. (2003). We Media: How Audiences ashapinging the Future of News and Information. A Seminal Report. Reston: The Media Centre at the American Press Institute. Retrieved from goo.gl/WSjaZc. [Accessed: $5^{\text {th }}$ April 2017]

Braun, J., \& Gillespie, T. (2011). Hosting the Public Discourse, Hosting the Public. Journalism Practice, 5(4), 383-398.

Brin, C., Charron, J., de Bonville, J. (2004). Nature et transformation du journalisme (Nature and transformation of journalism). Québec: Presses de l'Université Laval.

Cabrolié, S. (2009). La recomposition d'une organisation de presse: le cas du Parisien.fr (The recomposition of a press organization: the case of Parisien.fr). Terrain et travaux, 15(1), 127-145.

Cabrolié, S. (2010). Les journalistes du Parisien.fr et le dispositif technique de production de l'information (The journalists of Parisien.fr and the technical device of production of the information). Réseaux, 160-161, 79-100.

Carbonnel, A., \& Mercier, A. (2011). Web-journaliste: une identité fragile dans un contexte de mutations professionnelles (Web-journalist: a fragile identity in a context of professional changes). 22nd Congress of the AGRH. Retrieved from http://www. academia.edu/1983234. [Accessed: $4^{\text {th }}$ February 2017]

Cardon, D., \& Delaunay-Teterel, H. (2006). La production de soi comme technique relationnelle (Self-production as a relational technique). Réseaux, 138, 15-72.

Carr, D. J., Barnidge, M., Byung, G. L., \& Tsang, S. J. (2014). Cynics and Skeptics: Evaluating the Credibility of Mainstream and Citizen Journalism. Journalism \& Mass Communication Quarterly, 91(3), 452-470.

Cavelier Croissant, V. (2002). La presse quotidienne française sur Internet. Stratégies discours et représentations des acteurs français de presse quotidienne d'information générale dans le cadre du développement de leur site Internet (The French daily press on the Internet. Strategies speeches and representations of the French actors of daily newspaper of general information within the framework of the development of their Internet site). Thesis, Information and Communication Sciences, Stendhal University Grenoble, France. 
Charbonneaux, J., \& Le Cam F. (2012). Pratiques managériales et socialisation des journalistes en ligne (Managerial practices and socialization of journalists online). In G. D. Nguyen, \& P. Créach (Ed.), Le numérique en sociétés (Digital business), pp. 131-156. Paris: L'Harmattan.

Charon, J. M., \& Le Floch, P. (2011). La Presse en ligne (Online Press). Paris, La Découverte.

Charon, J. M. (2010). De la presse imprimée à la presse numérique. Le débat français (From the printed press to the digital press. The French debate). Réseaux, 160-161, 255-281.

Cheynel, N., \& Noblet, A. (2009). La mobilisation du mythe du journaliste-reporter sur le web, nouvel Eldorado participatif? (The mobilization of the myth of journalistreporter on the web, new participative Eldorado?). Retrieved from https://bit.ly/2Fql Zxe.[Accessed: 16th March 2017].

Collin, P. (2016). Autorégulation sociétale et autorégulation régulée - des catégories fécondes pour une analyse (juridico-) historique? (Societal self-regulation and regulated self-regulation - fertile categories for (juridico-) historical analysis?). Trivium, 21. Retrieved from https://bit.ly/2SXQSfx. [Accessed: 22th June 2018]

Datchary, C. (2010). Ce que le Web 2.0 fait à l'autonomie journalistique. L'expérience Médiapart (What Web 2.0 does to journalistic autonomy. The Médiapart experience). In C. Lemieux (Ed.), La subjectivité journalistique (Journalistic subjectivity), pp. 123-142. Editions de l'EHESS.

De Rosnay, J. (2005). Des mass média aux média des masses dans Agora Vox (From the mass media to the media of the masses in Agora Vox). Retrieved from https://bit.ly/2STqLGy. [Accessed: 22th October 2017]

De Rosnay, J., \& Carlo, R. (2006). La révolte du pronetariat - Des mass média aux média des masses (The revolt of the pronetariat - From the mass media to the media of the masses). Editions Fayard.

Deborah S. C. (2008). Interactive Features of Online Newspapers: Identifying Patterns and Predicting Use of Engaged Readers. Journal of Computer-Mediated Communication, 3, 658-679.

Degand, A., \& Grevisse, B. (2012). Journalisme en ligne, pratiques et recherches (Online journalism, practices and research). Bruxelles: de Boeck.

Demers, F. (2007). Déstructuration et restructuration du journalisme (Deconstruction and restructuring of journalism). Tic \& Société, 1(1). Retrieved from https://bit.ly/2H8E 3O9. [Accessed: 4th March 2017]

Deuze, M. (2004). What is Multimedia Journalism. Journalism Studies, 5(2), 139-152.

Deuze, M. (2005). What is journalism? Professional identity and ideology of journalists reconsidered. Journalism Theory Practice \& Criticism, 6(4), 443-465.

Deuze, M. (2008). The changing context of news work: liquid journalism and monitorial citizenship. International Journal of Communication, 2(5), 848-865.

Deuze, M., Bruns, A., \& Neuberger, C. (2007). Preparing for an age of participatory news. Journalism Practice, 1(3), 322-338.

Dupuy, C. (2013). Les Travailleurs du web: innovations et catégories professionnelles dans la presse en ligne (Web Workers: innovations and professional categories in the online press). Revue de l'IRES, 77, 107-127.

Estienne, Y. (2007). Le journalisme après Internet (Journalism after the Internet). Paris: L'Harmattan.

Fico, F., Lacy, S., Wildman, S., Baldwin, T., Bergan, D., Zube, P. (2013).Citizen Journalism Sites as Information Substitutes and Complements for United States Newspaper Coverage of Local Governments. Digital Journalism, 1(1), 152-168. 
Fielder, T. (2009). Crisis Alert: Barack Obama meets a Citizen Journalist. In S. Allan, \& E. Thorsen (Ed.), Citizen Journalism - Global Perspectives, pp. 209-221. New York: Peter Lang Publishing.

Flichy, P. (2001). L'imaginaire d'internet (The imagination of the internet). Paris: La Découverte.

Gillmor, D. (2004). We the Media: Grassroots Journalism by the People, for the People. Sebastopol: O'Reilly Media.

Goode, L. (2009). Social News, Citizen Journalism, and Democracy. New Media \& Society, 11(8), 1287-1305.

Lasica D. (2003). What is participatory journalism? Online Journalism Review. Retrieved from https://bit.ly/2e007IO. [Accessed: 22th June 2018]

Larsson, S. (2014). Battling Mainstream Media, Commentators and Organized Debaters: Experiences from Citizens' Online Opinion Writing in Sweden. Nordicom Review, $35(2), 77-89$.

Le Cam, F. (2005). L'identité du groupe des journalistes du Québec au défi d'Internet (The identity of the group of Quebec journalists to the challenge of the Internet). $\mathrm{PhD}$ Thesis. Laval University and the University of Rennes, France.

Le Cam, F. (2006). États-Unis: les weblogs d'actualité ravivent la question de l'identité journalistique (United States: news weblogs revive the issue of journalistic identity). Réseaux, 138. Retrieved from https://bit.ly/2AN7Vdr. [Accessed: $4^{\text {th }}$ March 2017]

Le Cam, F. (2012). Une identité transnationale des journalistes en ligne? (A transnational identity of online journalists?). In A. Degand, B. Grevisse (Ed.), Journalisme en ligne, pratiques et recherches (Online journalism, practices and research), pp. 61-85. Bruxelles: de Boeck.

Melissa, W. (2017). Mapping Citizen and Participatory Journalism. Retrieved from https://bit.ly/2FBbXbL. [Accessed: $4^{\text {th }}$ June 2017]

Mondoux, A. (2011). Histoire sociale des technologies numériques de 1945 à nos jours (Social History of Digital Technologies from 1945 to the present day). Québec: Éditions Nota bene.

Neveu, É. (2009). Sociologie du journalism (Sociology of journalism). Paris: La Découverte.

Newman, N. (2012). Social Media in the Changing Ecology of News. Retrieved from https://bit.ly/1FmAafU. [Accessed: $17^{\text {th }}$ June 2017].

Nobre-Correia, J. M. (2006). Journalisme: une certaine mort annoncée (Journalism: a certain death announced). Communication et langages, 147, 15-24.

Olivier, T. (2007). Le journalisme citoyen en ligne: un public réifié? (Online Citizen Journalism: A Reified Audience?). La Revue Hermès, 1(47), 115-122.

Peters, C., \& Broersma, M. (2013). Rethinking journalism: trust and participation in a transformed news landscape. New York: Routledge.

Pignard, N., \& Noblet, A. (2008). L'encadrement des contributions "amateurs" au sein des sites d'information: entre impératif participatif et exigences journalistiques (Supervision of "amateur" contributions within information sites: between participatory imperative and journalistic requirements). @SIC. Retrieved from https://bit.ly/2FxTcWV. [Accessed: 17th February 2018]

Pledel, I. (2006). Les blogs, les promesses d'un média à travers ses représentations collectives: illusions ou réalités à portée de clic? (Blogs, the promises of a media through its collective representations: illusions or realities at your fingertips?). Les cahiers du journalism, 16.

Rabia, N. (2017). Citizen Journalism vs. Mainstream Journalism: A Study on Challenges Posed. Athens Journal of Mass Media and Communication, 3(1), 55-76. 
Radsch, C. (2013). The Revolutions will be Blogged: Cyberactivism and the $4^{\text {th }}$ Estate in Egypt. Doctoral Dissertation, American University.

Rebillard, F. (2007). Le web 2.0 en Perspective: Une Analyse Socio-économique de l'Internet (The Web 2.0 in Perspective: A Socio-Economic Analysis of the Internet). Paris: L'harmattan.

Rebillard, F. (2008). Le journalisme participatif, un maillon dans la chaîne numérique de l'information d'actualité (Participatory journalism, a link in the digital news channel). In PROULX, Serge et Florence MILLERAND. Web social: mutation de la communication, pp. 15-30. Québec: Presses de l'Université du Québec.

Rosen, J. (2001). What are Journalists for? . New York: Yale University Press.

Ruellan, D. S. (2007). Penser le journalisme citoyen (Thinking citizen journalism). In Marsouin.org. Retrieved from https://bit.ly/2RwrYH6. [Accessed: 25th February 2018]

Schudson, M., \& Downie, L. (2009). The Reconstruction of American Journalism. Columbia Journalism Review. Retrieved from https://bit.ly/2Mcv90Z. [Accessed: 25th August 2017]

Singer, J. (2003). Who are these Guys? The Online Challenge to the Notion of Journalistic Professionalism. Journalism, 4(2), 139-163.

Singer, J. (2004). More than Ink-strained Wretches: The Resocialization of Print Journalists in the Converged Newsroom. Journalism \& Mass Communication Quarterly, 81(4), 838-856.

Sturgis, I. (2012). Are Traditional Media dead? Can Journalism Survive in the Digital World? New York: Idebate Press.

Tétu J. (2008). Du public journalisme au journalisme citoyen (From public journalism to citizen journalism). Questions de communication, 13, 71-88.

Tredan, O. (2007). Le «journalisme citoyen» en ligne: un public réifié? (Citizen journalism online: a reified audience?). La Revue Hermès, 47, 115-122.

Ward, Steven J. A. (2011). Ethics and the Media - An Introduction. Cambridge: Cambridge University Press. 



\title{
Ideology's Operation Mode in Domingo and Canal de Moçambique Newspapers during the Political-military Tension
}

\author{
By Isaías Carlos Fuel ${ }^{*}$ \& Sandra Mapilele ${ }^{*}$
}

\begin{abstract}
The Mozambican political system is characterized by several political parties. However, it is important in this article to analyze the expressiveness of the two major parties, which defend their interests and ideas in a quest to gain a favorable social representation. Doing so, they maintain and sustain a relation of dominance. The media are the key instruments in the dissemination of a party's propaganda, because it is through them that ideologies are disseminated to the population. The present research aims to analyze the ideology's operation modes of "Domingo" and "Canal de Moçambique" newspapers in 2013, at the peak of the political-military conflict, which involved Renamo, the opposition party, and the government led by the Frelimo party. The article is based on methodological depth hermeneutics; through a depth hermeneutic tool, the data demonstrate the projection of a meaning which resides in the legitimization of their actions. The discourse is presented in a rational way in order to create certain logic for their arguments. The data, also, illustrated that each party universalizes its interests, that is, the party's interests are presented as interests of the population. Finally, the use of fragmentation was demonstrated through expurgation, where the other is represented as an enemy to the national interests, so the population is called to support the party to fight against the national enemy.
\end{abstract}

Keywords: ideology, discourse, Frelimo, Renamo.

\section{Introduction}

There is no doubt that the media play an important role in building social understanding of everyday communities. They act as an influencer of attitudes, belief, behavior, and of the ways of thinking of a certain community. That is why, bringing the repercussion of the political-military conflict through the different ways in which the media take voice in the interpretation of reality, will give us an understanding of their leading role in this process. This article analyzes the ideology's operation modes of Domingo and Canal de Moçambique newspapers during the political-military tension in Mozambique, in 2013.

This theme, firstly, takes into account the concept of ideology, which according to Thompson $(2011$, p. 79$)$, refers to "ways in which meaning is mobilized by symbolic forms to serve, establish and sustain relations of domination through a continuous process of production and reception of the symbolic forms". It is important to add to this definition a reflection about the political context in which the political-military tension took place. The socialhistorical context in which the two newspapers report is a central element in order to perceive the discourses constructed with aim to sustain and maintain the

${ }^{*}$ Lecturer \& Researcher, Escola Superior de Jornalismo, Mozambique.

${ }^{\dagger}$ Lecturer \& Researcher, Escola Superior de Jornalismo, Mozambique. 
relations of domination of the two major political parties in Mozambique (Renamo and Frelimo).

Based on the method of depth hermeneutics, a sample of 12 articles of Domingo and Canal de Moçambique newspapers, published in 2013, were analyzed. This analysis was also based on three theoretical approaches on ideology, with the first approach evoking the discussion of Destutt de Tracy and the Bonaparte's perception of ideology. Second, the discussion focuses on the Marxist perception of ideology and Thompson's conception of it. Last, there is an analysis of the modus operandi of ideology within Domingo and Canal de Moçambique newspapers, under the light of Thompson's model.

\section{Theoretical Debate}

\section{Ideology}

The concept of ideology has presented, over time, different facets. Thompson summarizes the different meanings attributed to this concept in two categories: the first category comprises the neutral conceptions of ideology, and the second one includes the negative conceptions. This study explores the second category.

The neutral conception (Thompson, 2011, p. 44) can be visualized within Destutt de Tracy's thinking in 1796. According to Thompson (2011, p. 44), Desttut de Tracy describes ideology as a new project of a new science that aims to systematically analyze ideas and sensations. Thompson (2011, p. 72) says that the neutral conception claims that ideology does not imply developing illusory ideas, misleading or linked to the interest of any particular group. He adds that ideology is only an aspect of social life, like many others and it is not problematic.

The second category is characterized by the critical or negative conceptions of ideology. The starting point was given by Napoleon Bonaparte; he described ideologies as abstract, speculative and divorced from the reality of political power. This way of signifying ideology was embraced by Karl Marx, giving a new tone, which this study assumes. Marx views ideology as an instrument in the hands of the bourgeois class, aiming at manipulating and creating illusion in the proletarian class (Thompson, 2011, p. 54). This position was summarized by Thompson (2011, p. 51), as follows:

"Ideology, in this sense, is a theoretical doctrine and an activity which erroneously looks at ideas as autonomous and effective, and which cannot understand the real conditions and characteristics of socio-historical life".

It is also important to emphasize that, within the debate that Marx brings about ideology, there is the epiphenomenal conception that looks at the dependent and derived ideology of economic conditions, class relations and class production. Thus, ideology is defined as a system of ideas that expresses the interests of the ruling class, so it represents the class relations in an illusory way. Thompson (2011, p. 54) further explains: 
"Ideology expresses the interest of the ruling class, in the sense that the ideas that make up the ideology are the ideas that in a particular historical period articulate the optimistic ambitions, interests, and decisions of the dominant social groups, as they strive to secure and maintain their position of domination. Ideology represents class relations in an illusory way, because these ideas do not accurately represent the nature and relative positions of the interested classes, on the contrary, they misrepresent these relations in a way that favors the interests of the ruling class".

Within Marx's view of ideology, it is important to understand what this author calls the latent meaning. According to Hall (2003, p. 179) "ideology representation systems materialized in practice". These systems are composed of ideas, myths or images, in which men and women live their imaginary relations with the real conditions of existence. This author emphasizes that we must understand the systems of representation as "systems of meanings by which we represent the world for ourselves and for others". Taking Marx's view, Thompson asserts that this system of representation hides and misleads, and that in so doing, it serves to maintain the relations of domination (2011, p. 75).

However, Thompson emphasizes that the symbolic forms are not merely representations serving to conceal or obscure social relations or interests that are constituted fundamentally and essentially at the pre-symbolic level. On the contrary, symbolic forms are continually and creatively implied in the constitution of social relations. It is within this understanding that Thompson conceptualizes ideology in terms of "the ways in which meaning is mobilized by symbolic forms to serve and to establish and sustain relations of domination through a continuous process of production and reception of symbolic forms" (2011, p. 79). So, for Thompson, ideology must be seen as a:

"System of representations that serve to sustain the existing relations of class domination through the orientation of people to the past rather than to the future, or to images and ideals that conceal class relations and deviate from the collective quest for social change".

According to Thompson, the analysis of how the meaning is produced must respect the socio-historical analysis, which means that one must examine the social and historical conditions of the production, circulation and reception of the symbolic forms (2011, p. 34). Within the context, the analysis must take into account the social, political, economic, cultural and historical influences, since knowledge should not be a result of reflection of reality, but a social practices reflection (Hall, 2003, p. 170).

\section{Ideology's Operation}

As a way to understand how the meaning is generated, Thompson developed an instrument, by which it can be objectively perceived how in certain sociohistorical contexts men and women mobilize symbolic forms, in order to maintain 
and sustain the relations of domination. He presents five modes of operation of ideology: dissimulation, unification, fragmentation and reification (Table 1).

Table 1. Ideology's Operation

\begin{tabular}{|l|c|}
\hline \multirow{3}{*}{ Legitimation } & Rationalization \\
\cline { 2 - 2 } & Universalization \\
\cline { 2 - 2 } Dissimulation & Narrativisation \\
\cline { 2 - 2 } & Displacement \\
\cline { 2 - 2 } & Euphenization \\
\hline \multirow{2}{*}{ Unification } & Trope (Synecdoche, metonymy, metaphor) \\
\hline \multirow{2}{*}{ Fragmentation } & Standardization \\
\hline \multirow{2}{*}{ Reification } & Expurgation of the other \\
\cline { 2 - 2 } & Naturalization \\
\cline { 2 - 2 } & Externalization \\
\cline { 2 - 2 } & Nominalization/Passivization \\
\hline
\end{tabular}

The first ideology's operation mode is Legitimation. According to Thompson, there is legitimation of the discourse when the individual seeks to establish and sustain the ideology through legitimate actions, i.e. seeks to win the confidence of the population with pronouncements that demonstrate authenticity and truthfulness. Legitimation has three grounds: Rationalization, Universalization and Narrativisation.

According to Thompson, Rationalization is characterized by a symbolic construction organized in the form of a logical chain, seeking to sustain and justify the set of ideas, with the aim of persuading its public that their convictions are worthy of support. Universalization is the presentation of individual interests as the interest of all. Narrativisation consists in searching for old stories of success and mobilizing them in the present as a way of perpetuating and making the present situation acceptable.

The second ideology's operation mode is Dissimulation. In dissimulation, the relations of domination can happen and can be sustained through concealment, negation, or obscured in ways that divert the attention of individuals. Dissimulation can be expressed in forms such as Displacement, Euphemization and Trope. Displacement operates when the ideas that are used to refer to a particular subject/object are used to refer to the other, that is, to the positive or negative attributes of that object/subject. The strategy of Euphemism constitutes a symbolic construction with the objective of creating and sustaining actions in order to stimulate a positive appreciation of the ideology presented by the ruling class.

The Trope is a symbolic construction which employs the figurative use of language. Among the integrated strategies, we have: Synecdoche, Metonymy and Metaphor. Concerning synecdoche, Thompson $(2011$, p. 84) states that this strategy consists in using a term which refers to the whole. While metonymy, consists in the use of a term that takes the place of an attribute, of an adjunct. It is also possible to use a characteristic related to some thing to refer to the thing 
itself, although there is no necessary relation between the term and the thing to which it may refer. Within the trope as strategy, we find metaphor, where some terms are used even though they cannot be applied. Within this strategy individuals can be assigned characteristics that have no relation to them.

Unification is the third ideology's operation mode. In this strategy, ideas are mobilized or constructed to establish a certain unity between individuals or a collective identity, regardless of the differences and divisions that can separate them. Unification is branched into two symbolic forms, namely Standardization and Symbolization of unity.

Standardization is used for the purpose of symbolic exchange when seeking for a national standard language, which helps the creation of a collective identity among the various groups of society. The Symbolization of unity consists in the symbolic construction, with the aim of unification. Within these strategies, ideology is mobilized with the aim of building a collective identity through one or more groups.

In addition to the modes described above, we find Fragmentation, which consists in fragmenting individuals and groups instead of collectively unifying them. By doing so, a given group may be represented as threatening or dangerous, and it becomes legitimate to ban it within society. Within this symbolic construction, we find the differentiation and expurgation of the other. Differentiation is characterized by the ability to create a kind of division between people, for example Renamo and Frelimo in the case of the phenomenon under analysis in this study. The strategy of purging the other constitutes the creation of an enemy, whether internal or external, who is considered dangerous and threatening in the relations of domination.

The last operation's mode corpus of ideology within Thompson's classification is Reification. In Reification, power relations can be created and sustained from the socio-historical occultation of facts; Reification makes a "transitory, historical situation look as if this situation were permanent, natural, and timeless" (Thompson, 2011, p. 87). In this strategy there is an "elimination of the socio-historical character of phenomena" (Thompson, 2011, p. 88). The strategies used are: Naturalization, Externalization and Nominalization/ Passivization. Naturalization consists in presenting as natural a state of things that are socio-historical creations (Da Silva \& Verissimo, 2010, p. 8).

Externalization is a strategy similar to naturalization, where socio-historical phenomena are deprived of their historical character by being presented as permanent, immutable and recurrent. Thompson (2011, p. 88) explains that:

"Customs, traditions and institutions which seem to extend indefinitely in the past direction, so that every trace of their origin is lost and all questioning of their purpose is unimaginable, they acquire a rigidity that cannot be easily broken. They crystallize in social life, and their seemingly a-historical character is reaffirmed through symbolic forms, which, in their construction, as well as in their pure repetition, eternalize the contingent".

Within this mode, we have Nominalization and Passivation. Nominalization occurs when actions become the subject of actions, while Passivation occurs 
when the passive voice is used where agents are described passively. According to Da Silva \& Verissimo (2010, p. 8), "these two strategies are used in politics when addressing audiences in public speaking, on certain issues to the detriment of others".

\section{Problematic}

In order to understand the media's construction of meaning around the political-military crisis, it is important to capture two inseparable dimensions in this process, on one hand the national political scenario, on the other, the evolution of the role that the media have assumed.

\section{Mozambique Media Outlook}

The role played by the media took various dimensions, according to the transformations which took place in the social, political and economic structure in Mozambique. After independency (from 1975 to 1990), we can highlight that media were seen as an advanced instrument in the class struggle in the revolution. It was underlined during the First National Seminar on Information, from September $12^{\text {th }}$ to $15^{\text {th }}$ ，1977. In the words of Samora Machel, the first president of independent Mozambique, as cited in Chichava and Pohlmann (2010, p. 128), the first seminar emphasized that:

"...The Party must pay particular attention to the political framework of the journalists. In this sense, we will intensify the implementation of the structures of the Party within the newsroom..."

and also that:

"... The journalists [should] be aware that they occupy a position of combatant on the ideological front of the struggle of the working masses, so they must fully assume the interests and aspirations of the workers and peasants". (Chichava \& Pohlmann, 2010, p. 128)

In this vein, the Notícias, Diário's Newspapers, Radio Moçambique and the Televisão de Moçambique that appears later, just to mention a few examples, were under the Frelimo government control. It is within this scenario that the media operated, because Frelimo leadership used the media as "an important instrument to convey the ideals of the new regime and discourage or control hostile sectors and consolidate national unity" (Chichava \& Pohlmann, 2010, p. 128).

The second scenario has its foundations at the end of the civil war, which ended with the signing of the general peace agreements in Rome, on October $4^{\text {th }}$, 1992. As a consequence of the end of the conflict, Mozambique adopted a democratic and multi-party constitution that was reviewed in 2004, counting among many other advantages, the statement of freedom of speech and the press, 
and the right to information as a fundamental right of Mozambican citizens (Constitution of the Republic of Mozambique, 1990).

According to Joanguete (2013, p. 98), despite the Mozambican constitution establishing freedom, access to information and the press, "there is still a lack of legislation that would be more detailed and compatible with the current reality, and compatible with the great changes in the media sector". As a result of this deficit, the author states that a force was exercised by journalists and professional associations, so that a legal instrument regulating social communication is approved. It is within this scope that Law 18/1991, known as the press law, and the law on the right to information, Law 34/2014, were approved. Law 18/1991 establishes the rights and duties of the media, to indicate the chair of the Higher Council of Social Communication (CSCS) (Joanguete, 2013, p. 98). While the law on the right to information, Law 34/2014:

"...Regulates the exercise of the right to information, the materialization of the constitutional principle of the permanent democratic participation of citizens in public life and the guarantee of the fundamental rights..."

The same law, in Article 13, underlines that:

"The exercise of the right to information includes the right to request, seek, consult, receive and disclose information of public interest held by the entities defined in article 3 of the Law".

With Regard to censorship, the mother law prohibits censorship in relation to the exercise of freedom of speech and in relation to the right to information, as prescribed in article 48 , paragraph 2 :

"The exercise of freedom of speech, which includes the right to disseminate one's own thinking by all legal means, and the exercise of the right to information cannot be limited by censorship..."

According to Joanguete (2013, p. 99), while the law establishes zero tolerance against censorship, studies show that the government authorities exercise control over community radio, newspapers, radios, public and private television. In the same path, Xadreque ${ }^{17}$ (former Editor of the newspaper Público), speaking of political interference in the media, says:

"In the private newspapers, when there is a critical situation, they use the tactic of buying the newspaper and becoming partner; this has happened to several newspapers. As partners of the newspaper, they hire people of their trust to control the contents. They remove all enemy, in order to accommodate their individual and party interests. Even the first page of the newspaper is controlled by them (Xadreque, interview 2014)".

\footnotetext{
${ }^{17}$ Interview held in October 2014, in his office in Maputo.
} 
A study carried out in 2017 by MISA Mozambique, in order to determine the level of openness of private and public institutions in Mozambique, revealed that an attitude of fear and secrecy persists in the provision of information of public interest.

\section{Political Scenario in Mozambican}

Mozambique shares borders with Tanzania in the north; in the South, with South Africa and Swaziland; in the West, with Zimbabwe, Zambia and Malawi; in the East, it is bathed by the Indian Ocean. It occupies an area of $799,380 \mathrm{~km}^{2}$, divided administratively in 10 provinces: Maputo; Gaza; Inhambane; Sofala; Zambézia; Nampula; Cabo Delgado; Niassa; Manica and Tete respectively. From the point of view of identity, Mozambique is made up of several tribes that are worth mentioning: the Nyau, Scenes, Shonas, Makuas, Makondes, Tongas, Tsongas and Copi.

With regard to the political landscape, Mozambique has a political scenario based on a decade of liberation war that culminated in the victory of the Liberation Front of Mozambique (FRELIMO) and consequently the signing of the Lusaka agreements in Zambia in 1974, which followed the creation of a transitional government. The proclamation of independence came in June 1975, when Frelimo assumed power and declared at the third congress, in 1977, that Mozambique should be a one-party state with a Marxist orientation.

The internal cleavages within the Liberation Front of Mozambique (Brito et al., 2003, p. 21) made room for a post-independence war in 1976, which was seen by some as a "destabilization war" and by others as "civil war". Brito et al. (2003, p. 22) affirm that "the extremely centralized character of the Mozambican State, the access to the economic and power resources of the southern elite and the cleavages between urban and rural" are at the root of political dissatisfaction.

The war that has waged Mozambique to develop in order to build a better quality of life for its inhabitants, lasted 16 years and, as a result of long and intense talks between the government and Renamo, the peace was reached in the early 90s. According to Brito et al. (2003, p. 20), the starting point of the negotiations was in 1983, with the signing of the Nkomati agreement, which provided that both the government of Mozambique and the South African government would not lodge in their territory and support the activities of the opposition movements. Therefore, they began negotiating with Renamo, and the first attempts aimed to offer "an amnesty and integration of Renamo's members in Mozambican society" (Brito et al., 2003, p. 22).

Although the first talks between Frelimo and Renamo did not go as planned, Frelimo did not stop and other strategies were implemented. As a result, in the late 1980s, Frelimo abandoned the Marxist ideology and reviewed the constitution, and Mozambique changed from Popular Republic into the Republic of Mozambique. With the support of the Catholic Church and the international community (Sant'Egidio), negotiations between Frelimo and Renamo became possible, which culminated in signing the Peace Agreement on October $4^{\text {th }}, 1992$. Then, a new 
constitution created the conditions for the first multiparty elections in 1994, where the Frelimo party and its candidate won.

The permanent tension of distrust between Frelimo and Renamo was growing stronger day by day, because in all elections, Renamo would contest the results, alleging fraud and lack of transparency in the scrutiny. Beyond these motivations for tension, Brito et al. (2003, p. 55) state that Frelimo party's inconsistent policy, which does little to facilitate the integration of Renamo's leaders in economic and institutional life, undermines reconciliation in Mozambique.

The Renamo's dissatisfaction grows day-after-day, and the complaints take the direction of the lack of access to the institutions of the State, the Armed Forces and the National Commission of Elections (CNE). As a result of noncompliance with the demands, in 2009, the Renamo leader Afonso Dhlakama, after being defeated by Armando Guebuza, he threatened to restart the war. Years later, he settled in Sadjumdjira, where he began training veterans as a way to require a new political status in Mozambique.

The peak of the tension between Frelimo and Renamo was when the Renamo leader left Nampula to live in Sadjumdjira, where negotiations between the government and Renamo began. In these negotiations, two important issues were discussed: the question of greater representation in the Armed Forces and the revision of the electoral system. These negotiations failed and, as a result, on October $21^{\text {st }}, 2013$, the Mozambican defense forces attacked the residence of the Renamo's leader. In addition to this attack, there was a wave of attacks mainly to the police station and murders of members of both parties (Canal de Moçambique, 2013).

In the above described scenario, the media played their part in communicating the picture of the evolution of the political-military conflict and its impact, which reverberated throughout the national territory. The leading role of the two newspapers is the subject of this analysis: the extent to which they seek to signify the political-military events during the course of the conflict, in the year 2013. We take this stance believing, as other media scholars say, that media not only inform, educate and entertain; they also play a role in disseminating symbolic systems as a part of the state's ideological apparatus (Althusser, 1970, p.44). Through these established relations of domination, the question we raise is the following: how did the two newspapers portray the political-military period in 2013? We respond to this question below.

\section{Data Analysis}

The examination of ideology's operation modes in Domingo and Canal de Moçambique newspapers in relation to military hostilities was based on a deep hermeneutic analysis. According to Thompson (2011, p. 360), "the study of the ideology is based on the significant symbolic construction, susceptible of interpretations taking into account social and historical contexts, structured internally in different ways." Thompson (2011, p. 361) argues that interpretation/ reinterpretation takes into account a movement of synthesis of a creative 
construction of possible meanings mobilized within the political-military context for example.

At this stage, Thompson's model was used to investigate the publications of the Domingo and Canal de Moçambique newspapers during the intense period of the political-military conflict, seeking to understand how they mobilized ideologically to maintain and sustain relations of domination in relation to the political position of each media body.

The data analyzed below comes from the analysis of 10 reports, 1 editorial and 1 opinion, selected from the Canal de Moçambique and Domingo's newspapers. Regarding the Domingo newspaper, the following have been analyzed: a) news written on April $7^{\text {th }}, 2013$, page 4, entitled "Renamo não pode passar a vida a assustar o povo" (Renamo cannot spend his life scaring the people); b) news written on April 21 ${ }^{\text {st }}$, 2013, page 6, entitled "Diálogo não pode pôr em causa a Constituição" (Dialogue cannot call into question the Constitution); c) news written on May $5^{\text {th }}$, 2013, page 3, entitled "Bissopo envenena com discursos incendiários" (Bissopo poisoned with incendiary speeches); d) news written on June $30^{\text {th }}$, 2013, page 4, entitled "Incidentes de Muxúnguè não devem desestabilizar a paz (The incidents of Muxúnguè should not destabilize peace)"; e) news written on July $7^{\text {th }}$, 2013, page 25 , entitled "Há muito desemprego e não temos investimentos" (There is a lot of unemployment and we do not have investments); and finally, f) news written on October $27^{\text {th }}, 2013$, page 8, entitled "Actuação Legítima das Forças Armadas" (Legitimate performance of the Armed Forces).

While Canal de Moçambique's newspaper was analyzed through the following articles: a) news written on July $10^{\text {th }}$, 2013, page 2, entitled "Apertado o cerco à Dhlakama" (The siege of Dhlakama); b) editorial written on July $10^{\text {th }}$, 2013, page 9, entitled "A paz pode estar por um fio" (Peace can be hanging by a thread); c) news written on July $31^{\text {st }}, 2013$, page 16 , entitled "Dhlakama dá mais uma semana para produção de resultados" (Dhlakama gives another week to produce results); d) the opinion letter written on September $11^{\text {th }}, 2013$, page 10, entitled "Queremos paz no nosso seio" (We want peace in our bosom); e) news written on November $6^{\text {th }}, 2013$, page 2, entitled "Conflito armando intensifica-se na região centro" (Armed conflict intensifies in the center region); and finally f) news written on November $27^{\text {th }}, 2013$, page 5 , entitled "Dhlakama não pode mandar parar com os ataques" (Dhlakama cannot stop the attacks).

This analysis proceeded in two stages. In the first stage, we will present the ideological mobilization carried out by Domingo's newspaper and the Canal de Moçambique newspapers.

\section{Domingo Newspaper}

\section{a) Legitimation.}

Rationalization. The news written on October $27^{\text {th }}$, 2013, page 8 , use terms seeking to establish cause and effect, to stimulate a need for action in order to attack Sadjumdjira. The news described the attack as legal, as a national 
imperative and as if there were no alternative ways to deal with Renamo. This statement is underlined by the lawyer Pedro Macaringue, in the following terms:

"I do not see any unconstitutionality in this action. Any country that values itself and which has a duty to guarantee the tranquility of its people, and above all the physical integrity of its citizens, could not continue to watch impatiently the movement of the so-called security of the Renamo leader".

Along the same lines, João Roque Goncalves, Lawyer, stated that:

"The Mozambican State can legitimately pursue and dismantle any illegal force in the country. Any armed group that has constituted itself outside the laws must be dismantled, which means that the State does nothing else but complying with what is legislated, which is to destroy, to dismantle a hiding place that was used for the planning of Instability in the central region of the country".

These chains of arguments that legitimize an attack on the Renamo headquarters, ignored the real causes of the Renamo leader's withdrawal to settle in Sadjumdjira as underlined by Brito et al. (2003, p. 55), stating that the Frelimo party's inconsistent policy, which does little to facilitate the integration of Renamo's leaders into the economic and institutional life, undermines reconciliation in Mozambique. It is also important to emphasize that eliminating Renamo has a central meaning for the party of the day, because this is the only party that calls into question the maintenance of Frelimo in power, thus, ending it is a passport for the Frelimo elite to hold for long in power.

\section{b) Universalization.}

"I've been in Rome for two years and I've had patience. All the people must realize that it is not someone who acts like the way we would like him to act. A person who uses the people as his shield, threatens and kills the population, can imagine the complexity of the dialogue" (June $30^{\text {th }}, 2013$, Domingo, p. 4).

The use of the word "People" is called here to demonstrate that the attack on Sadjumdjira is in the interest of the Mozambican people, because the Mozambicans are dealing with an individual who is not open to dialogue; as Thompson (2011, p. 87) asserts, universalization as an ideological mode of operation, consists in presenting the individual or group interests as if they were collective. The mark of universalization as an ideological form is described as follows (Sixpence, 2013, p.6):

"We talk about the need to establish dialogue. But note: the greater dialogue that the Mozambicans had in the recent years was the one that ended the war. That is when the Mozambicans said no to war".

The fact that the author uses the word "Mozambicans" brings us to the idea that the discussion in Rome involved all Mozambicans. Thus, if they were 
involved, then they are aware of every process, so bringing this debate is a waste of time. This strategy may be fallacious, because the current scenario is a result of non-compliance with some dialogue in Rome.

With regard to the Universalization and Expurgation, the editorial of Domingo, May $5^{\text {th }}, 2013$ underlines:

\footnotetext{
"We, the Mozambicans, are united in peace and we will always respect dialogue and political tolerance. However, we will not sell our character at any price. We are a state of law and we have a constitution by which we govern. Renamo's constant appeals for foreign mediation reveal its unfocused nature".
}

In this citation, the ideas of Frelimo's party are presented as being in the interest of all, and Renamo is presented as the enemy of Mozambique's interests. However, it is important to underline that there is a tendency in this text to confuse Frelimo with the State, which takes us back to the one party era, lasting from 1975 to 1990. It is also worth noting that history has shown that, although it is said aloud that the Mozambicans can solve their own problems, it seems that some people, even if you play the drums, will not listen, like Renamo did.

\section{c) Unification.}

The Frelimo's ideology is also operated through the Unification mode. It is through the standardization of language that this speech is written on April $21^{\text {st }}, 2013$, page 6 :

"The calls for peacekeeping, reinforced by national unity and dialogue among all the living forces of the Mozambican society, have been highlighted in this edition of the Open and Inclusive Presidency".

The strategy of standardizing symbolic forms in order to have a national character, establishes a certain unity between individuals or a collective identity, regardless of the differences and divisions that can separate them. This helps in the creation of a collective identity between the various groups of the society. Thus, the use of the terms national unity, open and inclusive Presidency, aim to create a symbolic form where all are presented as equal and enjoy the same rights.

\section{d) Dissimulation.}

The emphasized statements of two Lawyers in Domingo newspaper, dated on October $27^{\text {th }}, 2013$, page 8 , "to guarantee tranquility and security" and "instability planning in the central region of the country" take us to Euphemization. According to Thompson, this strategy consists of a symbolic construction with the aim to create and sustain actions which stimulate a positive valorization of ideologies. This means that actions like beating, killing and destroying goods can be described as a way of restoring order. Thus, the authors describe the FIR's action as an action to guarantee tranquility, security and stability in the region. 


\section{e) Fragmentation.}

Differentiation. Fragmentation occurs through differentiation. It happens when the other is described as different, who has characteristics that do not fit with the others, and so he/she must be removed or eliminated. This strategy is demonstrated by the following quotation (Sixpence, 2013, p.8):

"It is unfortunate that there are certain Mozambicans who care to see the climate of war reinstalled in our country, instead of gathering their energy and strength to improve, to stop the poverty and all these start with each one".

Sixpence adds what the former President states (2013, p. 8):

"...Renamo and its leader, Afonso Dhlakama, have many difficulties in adapting to the rules of democratic coexistence and, above all, to integrate in a society where peace reigns, not the arms".

Looking at the two quotes, Renamo's representation is negative, meaning that this party does not deserve to act in the Mozambican political scene, where people live in peace. This strategy separates individuals based on their thinking and the colors of their party. In this way, being member of Frelimo means pro peace, while being member of the opposite party means pro war. Looking at Renamo as the only warmonger is fallacious. Because to not let others develop socially, economically and politically, is another form of war, says Da Silva and Verissimo (2010).

Another strategy used by the newspaper, within the mode of fragmentation, is the expurgation of the other. The expurgation of the other consists in creating the other as an enemy, whether internal or external, considered dangerous and threatening. This strategy is exemplified in the following paragraph: "Renamo cannot spend its life scaring the people". It can also be seen in the following passage: "The Mozambican people cannot live permanently frightened by the threats of Afonso Dhlakama's party". This can also be seen in the following lines (Domingo, July 7th, 2013, page 25): "Due to the presence of the Renamo armed men accompanied by their leader, investors felt threatened and decided not to continue investing here".

Looking at the citations above, the Renamo party is represented as the internal enemy of the Mozambique's people. This party is against development. In this way, it is targeted to be eliminated and all individuals are called to join, in order to displace it.

\section{Canal de Moçambique Newspaper}

\section{a) Legitimation.}

Rationalization. The news published on November $27^{\text {th }}, 2013$, written by Bernardo Álvaro, in the Canal de Moçambique newspaper, are quoting Renamo's Secretary General, Manuel Bissopo: 
"I think it is foolish to wonder whether the president can or cannot order his men to stop the attacks, because the president is the person being offended and his men know that their father is being offended, so they are doing what is necessary to be done in order to protect their father".

In the same path, the Canal de Moçambique newspaper published on Wednesday, November $6^{\text {th }}, 2013$, reports:

"Contrary to the intention of the dialogue that has been verbalized, the government ordered the troops to attack and occupy the residence of the leader of RENAMO, in the city of Beira, the headquarters of RENAMO. Last week, without a judicial mandate, although it is said that later appeared a mandate of a judge, the Defense Armed Forces of Mozambique and the FIR searched the RENAMO headquarters for arms, but no instruments of war were found in any of the facilities".

The comment that Renamo's men did what they could since their father was being offended, demonstrates the use of rationalization, to legitimize the continuity of Renamo's actions. In doing so, it is implied that Renamo must be supported because it is acting in self-defense. Here, the Mozambicans are called to support the Renamist cause, because they are facing an injustice against the leader.

\section{b) Fragmentation.}

Expurgation. The issue of November $7^{\text {th }}, 2013$ of the Canal de Moçambique newspaper reports:

"...Dhlakama guaranteed that, as from that day, both parties should stop appealing to the military. Unfortunately, in the same day we suffered an attack. October $21^{\text {st }}$ ended with a bombshell attack against his life".

The reporter presents Dhlakama as a man of peace, which brings us to differentiation, that seeks to emphasize certain characteristics. In doing so, we are led to expurgation, which consists in presenting the other as the enemy. Dhlakama is presented as a man of peace, while Emílio Guebuza is described as a warmonger, as dangerous and as an enemy of peace, who must be purged from leadership.

The use of the expurgation as an ideological strategy can be illustrated by the following phrase: "15 days have passed since the government troops attacked Sadjumdjira in an unsuccessful attempt to kill or capture the Renamo's leader, Afonso Dhlakama..." (Canal de Moçambique, 2013, p. 2). In the same way, an article written by Ivone Soares, on September $11^{\text {th }}, 2013$, underlines:

"Frelimo has now invented new ways to sow mourning in Mozambican's families in the central region of Mozambique. The esteemed reader should be reminded that, recently, RENAMO reported at press conferences that the Frelimo government ordered the PRM, FIR and FADM to walk from house to house to hunt and execute their demobilized members after the Muxúnguè's events". 
These citations present the President Emilio Guebuza and Frelimo as the enemy, who are killing innocent people, and the people is called to fight against them.

\section{c) Universalization.}

Another ideological tool that Canal de Moçambique newspaper uses is universalization, which consists in presenting the individual or group interests as if they belonged to everyone. On July 31 $31^{\mathrm{st}}$, 2013, the Canal de Moçambique newspaper quoted Dhlakama: "Guebuza is playing with the people, because this country does not belong to him or to José Pacheco, who represents the government in these talks". The use of Universalization can also be seen in another passage from the editorial of July $10^{\text {th }}, 2013$, page 9:

"[Renamo's soldiers] did not attack on the National Road again, [...] out of respect for society, Dhlakama and his commanders, in the last twenty years, have been able to respect the Rome's commitment, despite all the offenses, the vexations, many deaths of the party's members, the destruction of many of the party's headquarters and so many flags torn ".

The people are called here to understand that the Dhlakama's struggle does not defend his personal interests but the interests of the Mozambicans, because Renamo values the society's prosperity.

\section{d) Metaphor.}

The use of metaphor as an ideological element consists in the use of one term taking the place of another, even without any direct connection between them. This strategy can be seen in an article of July $10^{\text {th }}, 2013$, page 2 , in the subtitle, by Timóteo and Veloso, in the Canal de Moçambique newspaper, where a Dhlakama's statement is reported:

"If I leave Maputo and the Frelimo's parakeets approach a few kilometers more, they will be shot. This will be the end of peace in Mozambique, I guarantee you. It will be generalized in all the eleven provinces".

Characterizing the Government's forces as parakeets makes a very interesting comparison, and presents Frelimo as an irresponsible party leading inexperienced and innocent young citizens to war, where they will be unnecessarily killed.

\section{Conclusion}

It is clear to the present research that, according to Thompson's propositions, discourses are not ideological on their own, but they are dependent on the contexts; they depend on how they receive the differentiated symbolic forms, which translate them and give them meanings. Hence, in this research, an effort is 
made to present a reflection that intends to highlight the different ways in which the newspapers Domingo and Canal de Moçambique represented Frelimo and Renamo, with a view to maintaining asymmetric relations of domination in the politico-military context. The insistence on the use of rationalization, expurgation, dissimulation, metaphor and the universalization of their interests by the actors in this conflict, are marks of this domination.

The significance of the newspapers Domingo and Canal de Moçambique in relation to the actions of the Frelimo and Renamo parties in the case of the politico-military conflict, is linked to the maintenance and support of them in power. This occurs through the dissemination of symbolic discourses that start from the legitimation of their actions, and, in the same path, they seek to universalize their own interests and conclude in the presentation of the opposite party as an enemy for the national interests.

\section{References}

Althusser, L. (1970). Ideologia e aparelhos ideológicos de estado (Ideology and ideological state apparatuses). Retrieved from https://bit.ly/2TvAB1b.

Brito, L., Francisco, A., Pereira, J.C.G., Rosario, D. (2003). Moçambique 2003: Uma avaliação do potencial de conflito (Mozambique 2003: An assessment of the potential for conflict). Retrieved from https://bit.ly/2CQmPB0.

Canal de Moçambique (2013, October 30). Editorial: Conflito Arma(n)do (armed conflict). P. 6.

Chichava S., \& Pohlmann, J. (2010). Uma breve análise da imprensa moçambicana (A brief analysis of the Mozambican press). Retrieved from https://bit.ly/2CSLy7H.

Constitution of the Republic of Mozambique, 1990. Retrieved from https://publicofficialsfinancialdisclosure.worldbank.org/sites/fdl/files/assets/lawlibrary-files/Mozambique_Constitution_1990_\%28as\%20amended\%29_pt.pdf.

Da Silva, F. O., Verissimo, F. da Silva (2010). Análise dos Modos de Operação da Ideologia Politica do Partido dos Trabalhadores (Modes of Operation of the Political Ideology of the Workers' Part). Retrieved from https://bit.ly/2Ay6BuA.

Hall, S. (2003). Da diáspora: Identidades e mediações culturais (Diaspora: Cultural identities and mediations). Retrieved 03 october 2018 from https://bit.ly/2QqAdiJ.

Joanguete, C. (2013). As mudanças para o jornalismo digital na imprensa pública e privada Moçambicana: estudo comparativo dos jornais Notícias e a Verdade (The changes for digital journalism in the Mozambican public and private press: a comparative study of Noticias e Verdade's Newspapers). Retrieved from http://hdl.handle.net/1822/28789.

Misa Mocambique. (2017). Instituições Abertas e Fechadas: Relatorio de analise sobre o nível da implementação da Lei do Direito à informação em Mocambique ${ }^{l}$. Retrieved from http://www.misa.org.mz/index.php/destaques/noticias/17-misa-mocambiquelanca-relatorio-so bre-as-instituicoes-publicas-abertas-e-fechadas.

Sixpence, J. (2013). Diálogo não pode pôr em causa a Constituição (Dialogue can not call into question the Constitution). Domingo pp. 6-8.

Soares, I. (2013). Queremos paz no nosso seio (We want peace in our bosom). Canal de Moçambique p. 10. 
Timóteo, A., \& Veloso, F. (2013). Apertado cerco a Dhlakama: Entrada de Militantes e viatura está a ser impedido, desde esta terça-feira, por forças governamentais, no controlo da Vila da Gorogosa, na estrada para "cavalo" (Closed siege to Dhlakama: Militants and vehicle entrance is being blocked, from this Tuesday, by government forces, in control of Vila da Gorogosa, on the road to "horse"). Canal de Moçambique p. 2.

Thompson, J. B. (2011). Ideologia e cultura moderna: teoria social crítica na era dos meios de comunicação de massa (Modern Ideology and Culture: Critical Social Theory in the Age of Mass Media). Retrieved from https://bit.ly/2Hjajge. 



\title{
A Three Step Approach Analysis of the Portrayal of Images of Women in three Ghanaian Newspapers: Newsone, Ebony and The Mirror
}

\author{
By Henry Kojo Bonsu-Owu*
}

\begin{abstract}
Media portrayal of women in traditional stereotypical roles such as mothers, or seductresses has been the norm for years. However, the changing socioeconomic and political environment and advancement of women in today's society have given rise to questions on the appropriate portrayal of women in the media today. The purpose of the study is to analyze the portrayal of women in Ghanaian newspapers and find women's perception on the issue. The study uses a three step approach in gathering data for analysis. Using the stratified sampling method it analyzes front page images of women from 210 issues of the selected newspapers. Further, it administers questionnaires to 100 female students to find out how they relate to the images of women in the selected newspapers. Finally, editors of the newspapers are interviewed to find their rational for portraying women as seen on their front pages. The findings suggest that the newspapers portray women for varied reasons such as promoting sales and influencing the public agenda. Further, the female students claim that in spite of women's vast contribution to the growth of society, the media continue to marginalize them. They add that such portrayals promote and reinforce social construct, however they refuse to see themselves through the male gaze concept. The study concludes that the stereotyped portrayal of women is likely to continue if the government, regulatory bodies, the media and society do not make a conscious effort to address this problem.
\end{abstract}

Keywords: newspaper, portrayal, social construct, women.

\section{Introduction}

In Ghana, the media have played no mean role in the country's socio-political development. However, in spite of women's vast contributions to the national growth, the media seemingly continue to marginalize women. The social construction of women in stereotypical roles such as mother, helpmate, or seductress goes beyond how the public sees them to firming and institutionalizing such beliefs. Ghana's liberal media landscape however presents a new challenge for the media given rise to questions on the appropriate portrayal of women in the media.

\section{Background of the Study}

According to The Women's Manifesto for Ghana (2004) a liberalised media environment such as pertains in Ghana, with its commercial pressures, is bound to produce news and programmes that do not empower women or promote gender equity adding that the underlying commercial interests that govern the media

${ }^{*}$ Lecturer, Faculty of Journalism, Head of Department, Print Journalism, Ghana Institute of Journalism, Ghana. 
worldwide and perpetuate the axiom that "sex sells" are responsible for some of the common problems of women's representation (p. 50).

Treise, Weigold, Conna and Garrison (1994) add that the media fail to echo the changing roles of women and rather focus on them as sex objects, "happy homemakers"; incompetent, inferior and as subordinates to men. Therefore, not only are women underrepresented by the mass media, but they are also depicted unrealistically (p. 61).

Olorunpomi (2011) adds that

...it is quite offensive for (the media) to put such pictures on the pages of a newspaper, bearing in mind that we have not only an adult audience but also a youth audience. It goes to show we need to start monitoring what comes out of the media (para. 4).

\section{Problem Statement}

The level of social, economic, political and academic achievements of women in the 21 st century seem to suggest they would no longer be limited by their gender or steered into traditional roles (Paynter, 2011). However, studies by Anderson and Hamilton (2005), Diekman and Murnen (2004), Gooden and Gooden (2001), as cited in Paynter (2011) show that the media continue to portray images which stereotype women negatively.

Furthermore, studies by Blaha (2009), Cronn-Mills (2009), Ranchod (2007) which focused on the representation of women in magazine advertisements recommend further studies in a range of print media sources including newspapers so as to present a wider picture of the portrayal of women in the print media.

Though there exist lots of studies on newspaper portrayal of women (Olorunpomi, 2011; Jooste, 2007; Nwagbara, 2006; Potter, 1985) works cited within the Ghanaian context (Zaney, 2012; Quainoo, 2011; Zwennes, 1996; Mensa-Bonsu, 1992) tend to focus on state-owned newspapers such as the Daily Graphic, Ghanaian Times, Spectator and The Mirror. This study thus seeks to bridge the gap by analyzing the media's portrayal of women from three angles, firstly from the perspective of both private and state-owned newspapers. Additionally, it addresses the issue from the perspective of women themselves as most of the previous studies (Kang, 1997; Goffman, 1978) tend to look at the issue from the perspective of the male gaze, and finally from the perspective of editors of the newspapers.

\section{Objective of the Study}

The study's main objective is to analyze the portrayal of women in Ghanaian newspapers. The specific objectives of the study are as follows:

1. To explore how women are portrayed in the print media.

2. To investigate how women relate to the images of women as portrayed by the print media. 
3. To find the rational for the portrayal of women in the newspapers.

\section{Research Questions}

1. How are women portrayed in the print media?

2. How do women relate to the images of women as portrayed by the print media?

3. What is the rational for the portrayal of women in the print media?

\section{Significance of the Study}

The ability of the print media to inform and influence our basic thoughts, persuade and shape our beliefs gives it power over society (Thurm, 2001). It is therefore significant to look at the issue of the portrayal of women in newspapers as it will help shape society and indicate the importance of women in society. The study also provides insights into how women themselves react to such images that represent the diverse roles of the contemporary women.

Socially the study aims at creating consciousness of the place of the 21st century woman in nation building, and communicate to the public that the contemporary woman has gone beyond the traditional stereotype of being a home keeper or sex object for sale to become assertive and development minded and that they can be as resourceful and intelligent as any man.

\section{Scope of the Study}

The study is limited to images (pictures) from the front pages of two private owned Ghanaian newspapers Newsone and Ebony and a national weekly newspaper The Mirror over a five year period 2012-2017. The study also questions the rational for the portrayal of women in the print media from the viewpoint of the editors of the newspapers and how women also see such portrayals.

\section{Literature Review}

The review is categorized under the following sub-headings: The role of the media, Media and portrayal of women, Portrayal of women by newspapers, Stereotyping women in the print media, Women empowerment and Feminists' perception.

\section{The Role of the Media}

In an age of information and technological advancement the role of the media has gone far beyond the supply of information to giving them the power to create reality. Therefore by gradually shaping public opinion, personal beliefs and even people's self-perceptions, media influences the process of 
socialization and shapes ideology and thinking (Chopra, 2008). One such important media is the newspaper which continues to play a very significant role in the development of many countries the world over (Quainoo, 2011).

As gatekeepers of information, the media to a large extent regulate what we see and know by deciding what programmes to air, what news stories to feature, what images to show and how to represent people, issues and events (Woods 1994, as cited in Hammond, 1999).

\section{Stereotyping Women in the Print Media}

According to Abbam (1975), as cited in Gallagher (n.d., p. 15), the newspaper "has become more commercial and lively, partly through the use of women on its covers as sales bait". Quainoo (2011) adds that the Editorial Board of The Mirror over a decade ago adopted reader-oriented measures, one of it being the use of pretty faces of women on its cover pages to attract readership because of the perception that women are more attractive to readers.

Wella, Burnett and Moriarty (1992) define stereotyping as "presenting a group of people in an unvarying pattern that lacks individuality and often reflects popular misconceptions" (as cited in Nwagbara, 2006, p. 21).

Goffman (1978), as cited in Kang (1997), mentions that women are portrayed as weak via five categories, Relative Size (women shown smaller or lower, relative to men), Feminine Touch (women constantly touching themselves), Function Ranking (occupational), Ritualization of Subordination (proclivity for lying down at inappropriate times, etc.), and Licensed Withdrawal (women never quite a part of the scene, possibly via far-off gazes).

Kang (1997) introduces two more categories, Body Display as well as Independence and Self-Assertiveness. He states under Body Display that occasionally magazine advertisements show little pigeonholing of women in terms of relative size, feminine touch, function ranking, ritualization of subordination, and licensed withdrawal, the female models on the other hand show high degree of nudity which is another important way of stereotyping.

\section{Reducing Stereotype Roles of Women}

According to Nwagbara (2006), the call for a reversal in the stereotyping of women "would not have been necessary were stereotypes not dangerous. They are usually built on half-truths, distortions, sometimes untrue premises and this is made worse by the fact that stereotypes are resistant to change" (p. 24). Thus one can only imagine the effect such continuous exposure of the public to this kind of information will have on them. "In that circumstance, people will very easily come to accept lie for fact and myth for reality" (Nwagbara, 2006, p. 24).

Baldwin (1999), as cited in Thurm (2001), exploring sexualized imagery as power in advertising, focus on semiotic signifiers and how advertising and 
programming provide some of the social cues in the construction of Self ${ }^{18}$. Thurm (2001, p. 15) further mentions that "girls negotiate and construct their own gendered identities through different definitions of what it means to be a woman from the media", and Nwagbara (2006, p. 24) mentions that "herein in lies the real danger in stereotyping".

Some studies however indicate a gradual change in the stereotypical roles of women. Nwagbara (2006) adds that African women can be as intellectually capable as men if given the opportunity. Some of them serve as chief executives of large conglomerates, some hold sensitive political positions, a lot of them work outside the home, others are established business magnates while others are involved in varied lucrative ventures.

\section{Feminist Perspective}

Paglia (1992), as cited in Zimmerman and Dahlberg (2008, p. 72), notes that:

Third wave feminists now stress a new feminism; one that is not stiff and oldfashioned, but bold, fun, and in line with popular culture. This feminism embraces sexuality. It views sex as power. It separates women from men and sees women as the dominant sex.

Obenewaa (2007) also contends that a woman's right to respect, and equal treatment, and to be seen as a useful member of society has nothing to do with her sexual orientation. She adds that Ghanaian women are capable actors, and can demand equal rights from the state without giving in to the impositions of society's patriarchs.

\section{Methodology}

This research is based on an analysis of only photographs of women appearing on the front pages of two Ghanaian privately owned newspapers, Newsone and Ebony, and a state-owned weekly, The Mirror. It should therefore be noted that all other texts such as banner headlines, captions and copy text were not considered in this study. The sampling frame selected for this study was over a five year period from 2012 to 2017.

The study referred to categories used by previous researchers such as Blaha (2009), Cronn-Mills (2009), Ranchod (2007), and Kang (1997).

\section{Research Approach}

The study employed the mixed method approach to enhance its credibility. Furthermore, to increase the reliability of its findings the study employed

\footnotetext{
${ }^{18}$ Herbert Blumer theorizes that the Self exists because the individual can respond to himself as an object. It is one of Blumer's three cardinal concepts (Society, Self and Mind).
} 
triangulation $^{19}$. Images of women on the front pages of the three newspapers are analyzed and interpreted bringing out the most recurring categories and themes as portrayed by the three newspapers. Additionally, editors of two of the three newspapers, Newsone and The Mirror, were interviewed and the interviews transcribed, the approach to the interviews was unstructured; to make room for the interviewees' own perspectives on the issue at stake. Additionally the study used tables and figures in presenting the findings of the coders and that of survey questions posed randomly to female students of the Ghana Institute of Journalism to find out how they relate to the images of women as portrayed in the selected newspapers. It must however be noted that the tables and figures in this study were not subjected to strict quantitative statistical analysis but were used to generate frequencies and percentages which aided in the analysis of data.

\section{Research Design}

The research employed a five step procedure from the book, Investigating Communication: An Introduction to Research Methods (Frey, Botan, Friedman \& Kreps, 1991, as cited in Cronn-Mills, 2009). The step by step procedure includes: Selecting texts, determining the unit of analysis, developing content categories, coding units and analyzing the data.

\section{Selecting Text}

A purposive sampling method was used to select the sample. Since the focus of the study was to examine the portrayal of women in newspapers, Paradigmatic Case Sampling ${ }^{20}$ one of the several methods of purposive sampling as cited by Given (2008) in the Sage Encyclopedia (p. 697) was used in selecting Newsone and Ebony newspapers since the two newspapers seemingly mirror the portrayal of women as sex objects. Additionally, The Mirror newspaper, a national weekly, was purposively selected since it gives the greatest coverage on women based issues as compared to other state-owned newspapers such as The Daily Graphic and The Ghanaian Times (Asamoah, 1980). Moreover, Hammond (1999) mentions that weeklies have been generally known to cover more of stories about women.

\section{Sample Size}

In selecting the sample size Riffe, Lacy and Fico (1998), as cited in

\footnotetext{
${ }^{19}$ Triangulation in qualitative research has come to mean a multimethod approach to data collection and data analysis. The basic idea underpinning the concept of triangulation is that the phenomena under study can be understood best when approached with a variety or a combination of research methods. Triangulation is most commonly used in data collection and analysis techniques, but it also applies to sources of data (Given, 2008, p. 892).

${ }^{20}$ Paradigmatic Case Sampling: A case is paradigmatic when it is considered the exemplar for a certain class (Given, 2008, p. 697).
} 
Pedersen (2002), indicate that "the most efficient stratified sampling method for inferring to a year's content for newspapers is to sample two constructed weeks from the year" (p. 307). Accordingly, two constructed weeks constituting 14 issues per newspaper were randomly chosen as the sample from each of the 3 newspapers. The total sample size for this study was 210 issues, consisting of 42 issues from each newspaper, that is, one issue per month in a given year and two additional issues from any month within the same year (Stemple, 1952, as cited in Riffe, Lacy and Fico, 1998).

As mentioned, text for the study was selected from 210 issues of the three newspapers over a five year period (2012-2017) which works out as follows:

1. 1 Newsone newspaper +1 Ebony newspaper +1 Mirror newspaper $=3$ newspapers per month $\times 12$ months $=36$ newspapers per year.

2. 36 newspapers +6 ( 2 additional issues per paper from any month $)=42$ newspapers.

3. 42 newspapers $x 5$ years $=210$ newspapers.

According to Enu-Kwesi (2006) this process saves time and is likely to produce an unbiased sample.

\section{Determining the Unit of Analysis}

"A unit of analysis is the smallest element or indicator of the phenomenon of interest in a content analysis" ${ }^{21}$ (Kimani 2009, p. 66). Wimmer and Dominick (2003), as cited in Kimani (2009), note that unit of analysis "might be a single word or symbol, a theme or an entire article or story" (p. 66). The broad unit of analysis for this study consisted of only images of women as presented on the front pages of the three newspapers. Where a front page carried more than one picture of a woman or women the picture which covered more space in terms of size was analyzed for the study. Text and images of men were not considered in this study. The three major themes ${ }^{22}$ identified for this study are Facial Expression, Body Language and Clothing. At least one of the three themes was present in each of the newspapers. The recurring display of these themes within the selected unit of analysis, gave grounds to conducting an appropriate content analysis.

\section{Developing Content Categories}

Having identified the three major themes there was the need to place them within the most evident and prevalent content categories (Cronn-Mills, 2009). The categories were based on the kind or level of exposure of female sexuality on the front pages of the selected newspapers. The most reoccurring issues in line with

\footnotetext{
${ }^{21}$ According to Reinard (2008, p. 302), as cited in Cronn-Mills (2009), content analysis is a research technique which is applied in defining and systematically analyzing the content of transcribed, verbal, or pictorial communication.

${ }^{22}$ Frey et al. (1991) as cited in Cronn-Mills (2009) indicate that thematic units are the issues enclosed within messages.
} 
Blaha's (2009) study were chosen as my six categories:

1. Facial Expression.

2. Body Language.

4. Percentage of Coverage.

5. Camera Angle.

6. Degree of Clothing.

7. Type of Clothing.

Additionally, subcategories ${ }^{23}$ were identified within each of the above categories.

\section{Coding Units}

Wimmer and Dominick (2003), as cited in Kimani (2009), note that "placing a unit of analysis into a content category is called coding" (p. 67). Charmaz (1983, p. 111), as cited in Lindlof and Taylor (2002, p. 216), adds that "Codes...serve as shorthand devices to label, separate, compile and organize data". To indicate the core purpose of coding, Lindlof and Taylor (2002) note that "...coding is to mark the units of text as they relate meaningfully to categories (concepts, themes, constructs)" (p. 216). Additionally, Baran (1999, p. 352), as cited in Pawlowski (2007), describes a coding schedule as an instrument that allows a "valid and reliable category scheme to count the number of times a piece of content fits each category" (p. 41).

The coding system designed for this study looked at the diverse aspects of how female sexuality is portrayed by the three newspapers. The categories that were coded in accordance with Blaha (2009) include percentage of coverage, facial expression, body language, degree of clothing, type of clothing. The following subcategories were indicated within each of the categories:

\section{Facial expression subcategories}

Neutral: when the woman has no expression.

Smiling: when the woman has an open mouthed smile with teeth, or closed mouth smile.

Seductive: placing a finger or object in or near her mouth, blowing a kiss, red hot wet lips, sleepy sexy eyes or running her tongue over her lips.

Other: an expression of the woman that does not fit the above categories.

$N / A$ : when the expression of the woman is not visible.

\section{Body language subcategories}

Courteous: when the woman is not flaunting her body in a sexual way.

Dominant: when the audience gets the feeling that the woman has power or authority by the way she is standing or the way her body is positioned near an object.

\footnotetext{
${ }^{23}$ Subcategories as described under Coding Units.
} 
Submissive: when the woman is portrayed as a wife or mother. Or does not appear confident (head is down, shoulders were rounded down).

Sexual: when majority of skin is shown or the body language implies sex by placement of hands and pose of body (e.g. when the woman is in a sexual pose like sitting with her legs wide open).

Other: a pose that does not fit in the above categories.

\section{Percent of coverage subcategories}

Full Page: means the woman's image is more than $50 \%$ of the whole cover page.

Half Page: when the woman's image covers at least $50 \%$ of the page.

Quarter Page: when the woman's image covers $25 \%$ of the page

Less than Quarter Page: when the woman's face covers less than $25 \%$ of the page.

\section{Camera angle subcategories}

90 degrees: when the woman is looking right into the camera.

45 degrees: when the woman's face is showing sideways

Away from camera: when the woman's gaze is away from the camera.

Gaze Not Visible: the woman's gaze was not visible, e.g. in sunglasses and head is at an angle other than 90 degrees.

\section{Type of clothing subcategories}

Casual: clothing suitable for wearing on informal occasions, e.g. jeans, mini skirt, t-shirt or blouse.

Formal: clothes suitable for an important occasion, office or meetings, e.g. a full-length dress or suit.

Lingerie: underwear, nightgown or bathrobe, a one piece or two-piece swimsuit, or bikini.

Traditional: clothing deemed to be Ghanaian or African, e.g. Kente, Kaba and Slit.

Other: where image as shown does not fit the above categories.

6. Degree of clothing subcategories

Nude: woman with no clothing on.

Seminude: woman dressed with very little clothing (e.g. bikini or just a wrapper round her waist) with a greater part of her body such as breast/upper body, buttocks, crotch, and legs showing.

Fully dressed: woman whose dress covers most of her sensitive parts such as breast, buttocks, midsection and thighs.

Other: where image as shown does not fit the above categories.

Body part shown: breast/cleavage, buttocks, genitals, legs (thighs and calves) and midsection (between chest and waist). 


\section{Reliability and Validity}

"To avoid measurement errors and to ensure reliability and accuracy of the findings" (Du Plooy, 2002, as cited in Ranchod, 2007, p. 33) pretesting of the coding instrument was undertaken to work out any coding problems. For pretesting, sample questionnaires were tested on 20 female students of the Ghana institute of Journalism. Additionally, 48 issues of the three newspapers were randomly picked. Of this number two coders were given the same set of 20 randomly picked issues. The pre-testing helped clarify the "coding categories, instructions, key terms, and definitions and provided familiarity with the coding process" Ranchod (2007, p. 33).

Johnson and Christensen (2008) mention that by testing for inter coder reliability a researcher is able to moderate the level of subjectivity and also decrease errors that may result from the varying backgrounds or experiences of the coders. A composite reliability coefficient was therefore computed using Holsti's (1969) technique, as cited in Tsegah (2009) and Kang (1997). The coefficient as per Holsti's formula is calculated as follows:

$$
\text { Percentage of agreement }=\frac{\text { Agreement }}{\text { Agreement }+ \text { Disagreement }}
$$

or $P A o=\frac{2 A}{n 1+n 2}$ where $P A_{\mathrm{o}}$ is the proportion agreement observed, $A$ is the number of agreements between two coders, $n_{1}, n_{2}$ are the respective number of items coded by each of two coders (Neuendorf, 2002).

According to Holsti (1969), as cited in Tsegah (2009), " $\mathrm{p}_{\mathrm{i}}$ is always greater than zero and less than one, where zero indicates a perfect disagreement, and one indicates a perfect agreement" (p. 68). The inter-coder agreement for the pretesting was $0.85(17 /(17+3)=0.85)$ which indicated an agreement among the coders.

For the main study, two coders were asked to independently examine the same set of 42 randomly picked newspapers (14 issues of each newspaper) representing $20 \%$ of the total sample size. The coefficient was calculated as follows:

$$
\frac{38 \text { agreements }}{38 \text { agreements }+4 \text { disagreements }}=0.90
$$

indicating a $\mathrm{p}_{\mathrm{i}}$ greater than zero and less than one thus an agreement among coders.

\section{Analyzing the Data}

Guided by previous studies such as Blaha (2009), Tsegah (2009), Kimani (2009), and Pedersen (2002) a coding sheet was designed to document the frequency of units in each category. Additionally three coders ${ }^{24}$ (Level 400

\footnotetext{
${ }^{24}$ According to Babbie (2004), as cited in Ranchod (2007), a coder is "someone, trained by the researcher, to locate the variables and interpret the codes" (p. 33).
} 
students of Ghana Institute of Journalism (GIJ) operating independently of each other were chosen and briefed by the researcher about the various subcategories they were going to use in conducting the coding which according to Tsegah (2009) would help the coders acquaint with the demands of the study and afford both the researcher and coders the chance of reducing any misconceptions. The coders were guided by a coding system provided by the researcher adopted from Blaha's (2009) study.

After an inter coder reliability of 0.90 based on $20 \%$ of the total sample size was established, the remaining $80 \%$ representing 168 newspapers were randomly divided between and coded by all three coders. Responses generated by the coders were processed and presented by the researcher in tabular form using Microsoft Excel \& Word software for easy interpretation and analysis.

A second step was to transcribe the interviews granted the editors of the newspapers. This was achieved by repeatedly playing back the recorded interviews and then transcribing the text which aided in revealing recurring themes, each theme was given a marker descriptive of its content and this was reviewed several times in an effort to reduce the researchers own interpretations upon the findings.

Finally, questionnaires were administered to a total of 100 female students of the Ghana Institute of Journalism. Their responses to the survey questionnaires were analyzed and presented in tabular and bar chart form.

\section{Population}

The population for this study comprised three newspapers Newsone, Ebony and The Mirror over a five year period (2012-2017) with only images of women from the front pages of the three newspapers serving as units of analysis; editors of the selected newspapers and female students of the Ghana Institute of Journalism. The population was sampled purposively to aid in answering questions raised by the study and its objectives.

\section{Distribution of Respondents by Programme and Area of Specialization}

All 60 respondents selected to answer the questionnaire were female students from the Ghana Institute of Journalism. In order to get a wider frame of responses the study chose 20 Regular Level 300 students, 20 Regular Level 400 students and 20 weekend Top-Up Level 400 students. For each group of 20 , the study further expanded the scope of respondents by area of specialization thereby picking 10 students of Public Relations and 10 students of Journalism from each level.

\section{Research Instruments}

The research instruments used in this study include interviews, questionnaires and newspapers. The interviews were unstructured which according to Given (2008) makes room for the interviewees' own perspectives 
on the issue at stake. The questionnaires on the other hand employed both open and close ended questions. Given (2008) notes that closed ended questions are posed by researchers to participants in research projects that specify the parameters within which participants can frame their answers whiles opened ended questions are designed to give participants freedom to initiate topics within research settings (p. 83). The newspapers were selected purposively to enable the researcher gather enough data for content analysis.

\section{Data Analysis Technique}

The data gathered were analyzed using the following techniques:

Firstly the recorded interviews were transcribed to bring out the most recurring themes, secondly the survey questions were analyzed in tabular form (frequency and percentage) using Microsoft Excel \& Word software, and finally content analysis of the selected newspapers were categorized, coded and presented in tabular form using Microsoft Excel \& Word software.

\section{Setting for Interviews}

In order to guarantee privacy and confidentiality interviews were conducted at the offices of the respective editors on an appointment basis at mutually convenient times. The locations were chosen on the assumption that they would provide a setting not only conducive to further disclosure but also appropriate should any of the interviewees need further sources of reference.

\section{Findings and Analysis}

\section{How are Women Portrayed in the Newspapers?}

The findings are based on three major themes identified (Facial expression, Body language and Clothing) and further analyzed under six categories (Facial expression, Body language, Percentage of coverage, Camera angle, Degree of clothing and Type of clothing) as per Blaha's (2009) study.

\section{Facial Expression Subcategories}

This category reveals how the selected newspapers portray the characteristics of women through their facial expressions, looking at the perceptual impressions they leave on the minds of readers and the general concept these images tend to invoke. Facial Expression was divided into five subcategories Neutral (woman has no expression on her face), Smiling (woman has an open or closed mouth smile), Seductive (placing a finger or object in or near her mouth, blowing a kiss, red hot wet lips, sleepy sexy eyes or running her tongue over her lips), Other (expression is visible but does not fit the above categories) and Not Applicable (expression of the woman is not visible). 
As shown in Table 1, the Smiling and Seductive subcategories returned the most scores. Under the Smiling subcategory The Mirror newspaper returned the highest score of $83.93 \%$. Of all the three newspapers the Ebony had the most tendency of portraying sexualized images of women (Seductive, $78.57 \%$ ) under the category of facial expression. Blaha (2009) submits that the print media portrays sexualized images of women on the basis that $75 \%$ of women were seen to have seductive facial expressions as against $20 \%$ just smiling. The total results of the facial expression category for this study portrays a different picture with $51.79 \%$ of the women depicted as just smiling, while $40.48 \%$ were depicted as seductive thus suggesting a decrease in the use of facial expression to portray sexualized images of women by the Ghanaian newspapers.

Table 2. Frequency and Percentages of Facial Expression Subcategories per Newspaper

\begin{tabular}{|l|c|c|c|c|c|c|c|c|}
\hline Subcategory & \multicolumn{2}{|c|}{ Newsone } & \multicolumn{2}{c|}{ Ebony } & \multicolumn{2}{c|}{ The Mirror } & \multicolumn{2}{c|}{ Total } \\
\hline & Freq. & $\%$ & Freq. & $\%$ & Freq. & $\%$ & Freq. & $\%$ \\
\hline Neutral & 2 & 3.57 & 1 & 1.79 & 6 & 10.71 & $\mathbf{9}$ & $\mathbf{5 . 3 6}$ \\
\hline Smiling & 30 & 53.57 & 10 & 17.85 & 47 & 83.93 & $\mathbf{8 7}$ & $\mathbf{5 1 . 7 9}$ \\
\hline Seductive & 22 & 39.28 & 44 & 78.57 & 2 & 3.57 & $\mathbf{6 8}$ & $\mathbf{4 0 . 4 8}$ \\
\hline Other & 1 & 1.79 & 1 & 1.79 & 1 & 1.79 & $\mathbf{3}$ & $\mathbf{1 . 7 9}$ \\
\hline N/A & 1 & 1.79 & 0 & 0.00 & 0 & 0.00 & $\mathbf{1}$ & $\mathbf{0 . 5 9}$ \\
\hline Total & $\mathbf{5 6}$ & $\mathbf{1 0 0 . 0 0}$ & $\mathbf{5 6}$ & $\mathbf{1 0 0 . 0 0}$ & $\mathbf{5 6}$ & $\mathbf{1 0 0 . 0 0}$ & $\mathbf{1 6 8}$ & $\mathbf{1 0 0 . 0 0}$ \\
\hline
\end{tabular}

Source: Sampled newspapers, 2018.

Notwithstanding, all three newspapers were found to use facial expression as a sign in defining the Ghanaian woman. For example in Figure 1, Newsone carries a sexually suggestive image of Afia a popular Ghanaian songstress suggestively running her tongue over her lips, the Ebony carries the image of a model with sleepy sexy suggestive eyes while The Mirror has an image of Ghanaian actress Lydia Forson also portraying sexy suggestive eyes coupled with a Mona Lisa ${ }^{25}$ smile. These images buttress Ranchod's (2007) assertion that "women in visual images connote 'to-be-looked-at-ness', to play the role of being desirable" (p. 23).

Figure 1. Sample Images of Newspaper Coded under Facial Expression Category

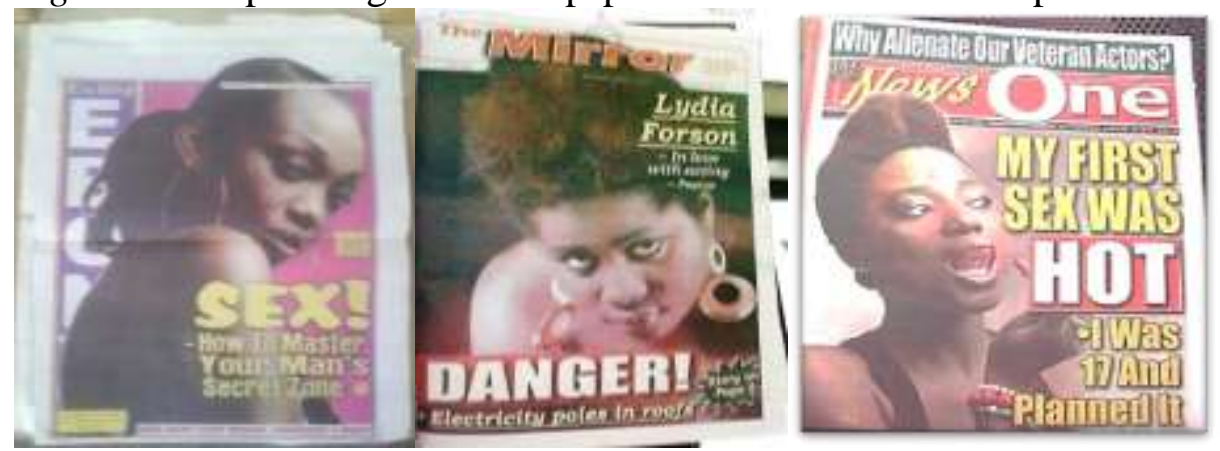

Source: Sampled newspapers, 2018.

\footnotetext{
${ }^{25}$ A 14th century painting by Leonardo da Vinci which depicts the female subject's smile as blurry, ambiguous and up to the imagination, one moment the smile seems to be there the next it's gone.
} 
From another angle these images tend to portray female icons like Afia and Lydia Forson as divas ${ }^{26}$ supporting Thurm's (2001) assertion that "the stereotypic character traits attributed to women have shifted from weak and dependent to strong and autonomous" (p. 3). The bold statement made by the portrayal of such images tend to back Zimmerman and Dahlberg's (2008) contention that the new wave of feminists now push a new agenda for feminism; one that is not rigid or conservative, but encourages women to be bold, and assertive adding that women should embrace sexuality and use their sex as a source of power (p. 72).

\section{Body Language}

This category was further divided into five subcategories, Courteous (woman is not flaunting her body in a sexual way), Dominant (image of woman depicts power or authority), Submissive (woman is portrayed as a wife or mother or does not appear confident), Sexual (majority of skin is shown or the body language implies sex) and Other (a pose that does not fit in the above categories).

Table 3. Frequency and Percentages of Body Language Subcategories per Newspaper

\begin{tabular}{|l|c|c|c|c|c|c|}
\hline Subcategory & \multicolumn{2}{|c|}{ News One } & \multicolumn{2}{c|}{ Ebony } & \multicolumn{2}{c|}{ The Mirror } \\
\hline & Freq. & $\%$ & Freq. & $\%$ & Freq. & $\%$ \\
\hline Courteous & 5 & 8.93 & 0 & 0.00 & 19 & 33.93 \\
\hline Dominant & 9 & 16.07 & 2 & 3.57 & 12 & 21.43 \\
\hline Submissive & 1 & 1.79 & 0 & 0.00 & 17 & 30.36 \\
\hline Sexual & 41 & 73.21 & 53 & 94.64 & 8 & 14.29 \\
\hline Other & 0 & 0.00 & 1 & 1.79 & 0 & 0.00 \\
\hline Total & $\mathbf{5 6}$ & $\mathbf{1 0 0 . 0 0}$ & $\mathbf{5 6}$ & $\mathbf{1 0 0 . 0 0}$ & $\mathbf{5 6}$ & $\mathbf{1 0 0 . 0 0}$ \\
\hline
\end{tabular}

Source: Sampled newspapers, 2018.

Responses from Table 2 indicate that $33.93 \%$ of the images sampled in The Mirror portrayed the body language of women as courteous, with Newsone recording $8.93 \%$ under the same subcategory; it is significant to note that Ebony did not have a single issue coded as courteous. Under the Dominant subcategory The Mirror led with $21.43 \%$ followed by Newsone with $16.07 \%$ and Ebony 3.57\%. The Mirror again led with 30.36\% under Submissive with Newsone returning $1.79 \%$ and Ebony again not having a single issue coded. However, the trend changed under the Sexual subcategory where the portrayal of women in a sexual body pose was found to be a reoccurring subject in both the Ebony (94.64\%) and Newsone (73.21\%) newspapers. These findings are consistent with previous findings by Cronn-Mills (2009), Blaha (2009), Ranchod (2007), Lindner (2004) that the print media portray women in sexually explicit ways, pointing "to the stereotype of the seductress, whereby her power lies in her ability to seduce or entice readers" (Ranchod, 2007, p. 46).

\footnotetext{
${ }^{26}$ Diva: A glamorous and successful female performer or personality as defined in the MerriamWebster online dictionary. Retrieved from https://www.merriam-webster.com/dictionary/diva.
} 


\section{Percentage of Coverage}

The percentage of the coverage category was divided into Full Page (woman's image is more than 50\% of the whole cover page), Half Page (when the woman's image covers at least $50 \%$ of the page) Quarter Page (woman's image covers $25 \%$ of the page) Less than Quarter Page (woman's image covers less than $25 \%$ of the page).

Table 4. Frequency and Percentages of Percent of Coverage Subcategories

\begin{tabular}{|l|c|c|c|c|c|c|c|c|}
\hline Subcategory & \multicolumn{2}{|c|}{ News One } & \multicolumn{2}{|c|}{ Ebony } & \multicolumn{2}{c|}{ The Mirror } & \multicolumn{2}{c|}{ Total } \\
\hline & Freq. & $\%$ & Freq. & $\%$ & Freq. & $\%$ & Freq. & $\%$ \\
\hline Full Page & 39 & 69.64 & 55 & 98.21 & 28 & 50.00 & 122 & 72.62 \\
\hline Half Page & 12 & 21.43 & 1 & 1.79 & 21 & 37.50 & 34 & 20.24 \\
\hline Quarter Page & 5 & 8.93 & 0 & 0.00 & 7 & 12.50 & 12 & 7.14 \\
\hline Less than Quarter Page & 0 & 0.00 & 0 & 0.00 & 0 & 0.00 & 0 & 0.00 \\
\hline Total & $\mathbf{5 6}$ & $\mathbf{1 0 0 . 0 0}$ & $\mathbf{5 6}$ & $\mathbf{1 0 0 . 0 0}$ & $\mathbf{5 6}$ & $\mathbf{1 0 0 . 0 0}$ & $\mathbf{1 6 8}$ & $\mathbf{1 0 0 . 0 0}$ \\
\hline
\end{tabular}

Source: Sampled newspapers, 2018.

Table 3 shows that the Ebony newspaper displayed a lot more of full page images $(98.21 \%$ ) than the other newspapers. Newsone also recorded $69.64 \%$ full page images whereas The Mirror had 50\%. For half page images The Mirror had $37.50 \%$, Newsone $21.43 \%$ and Ebony $1.79 \%$. The Mirror returned $12.50 \%$ of quarter page images against $8.93 \%$ by Newsone. None of the newspapers portrayed images of women less than quarter page.

The findings from Figure 2, point that 122 issues of the total newspapers sampled representing $72.62 \%$ carried full page images of women, alluding to Quainoo's (2011) submission that newspapers use women on their cover pages to entice readership because of the perception that women are more likely to attract readers.

Figure 2. Total Frequency of Percent of Coverage Subcategories

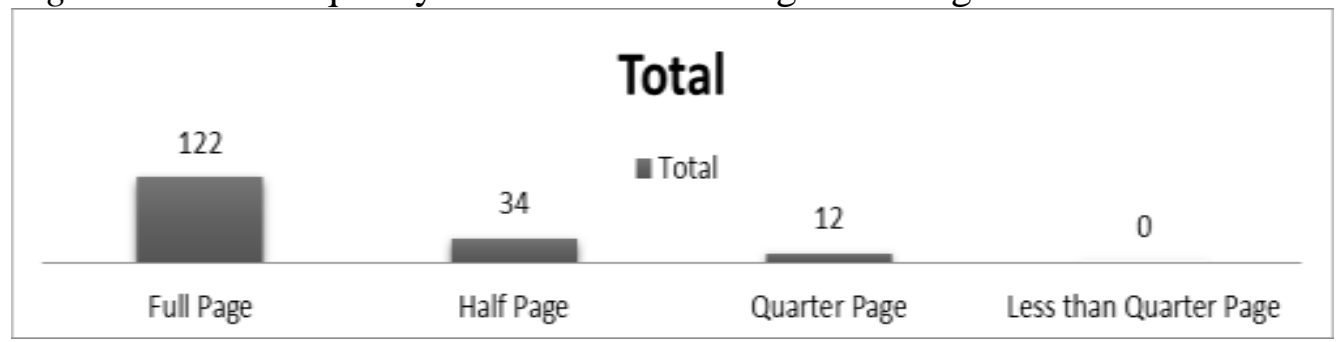

Source: Sampled newspapers, 2018.

\section{Camera Angle}

According to Ranchod (2007), portraying a woman's face underlines her distinctive characteristics and that a faceless woman displays no personality. This category looks at the various angles from which the images of women are portrayed in the newspapers. The category is divided into 90 degrees (woman is looking right into the camera), 45 degrees (woman's face is showing sideways) 
Away from camera (woman's gaze is away from the camera) and Gaze Not Visible (woman's gaze is not visible).

Table 5. Frequency and Percentages of Camera Angle Subcategories per Newspaper

\begin{tabular}{|l|c|c|c|c|c|c|c|c|}
\hline Subcategory & \multicolumn{2}{|c|}{ News One } & \multicolumn{2}{c|}{ Ebony } & \multicolumn{2}{c|}{ The Mirror } & \multicolumn{2}{c|}{ Total } \\
\hline & Freq. & $\%$ & Freq. & $\%$ & Freq. & $\%$ & Freq. & $\%$ \\
\hline $90^{\circ}$ & 22 & 39.29 & 32 & 57.14 & 35 & 62.50 & 89 & 52.97 \\
\hline $45^{\circ}$ & 27 & 48.21 & 24 & 42.86 & 21 & 37.50 & 72 & 42.86 \\
\hline Away from camera & 5 & 8.93 & 0 & 0.00 & 0 & 0.00 & 5 & 2.98 \\
\hline Gaze Not Visible & 2 & 3.57 & 0 & 0.00 & 0 & 0.00 & 2 & 1.19 \\
\hline Total & $\mathbf{5 6}$ & $\mathbf{1 0 0 . 0 0}$ & $\mathbf{5 6}$ & $\mathbf{1 0 0 . 0 0}$ & $\mathbf{5 6}$ & $\mathbf{1 0 0 . 0 0}$ & $\mathbf{1 6 8}$ & $\mathbf{1 0 0 . 0 0}$ \\
\hline
\end{tabular}

Source: Sampled newspapers, 2018.

Responses from Table 4 indicate that $62.50 \%$ of images from The Mirror portrayed woman at an angle of 90 degrees, with Ebony and Newsone returning $57.14 \%$ and $39.29 \%$ respectively. Under the 45 degrees subcategory Newsone had 48.21\% followed by Ebony with $42.86 \%$ and The Mirror with $37.50 \%$.

Figure 3. Total Frequency of Camera Angle Subcategories

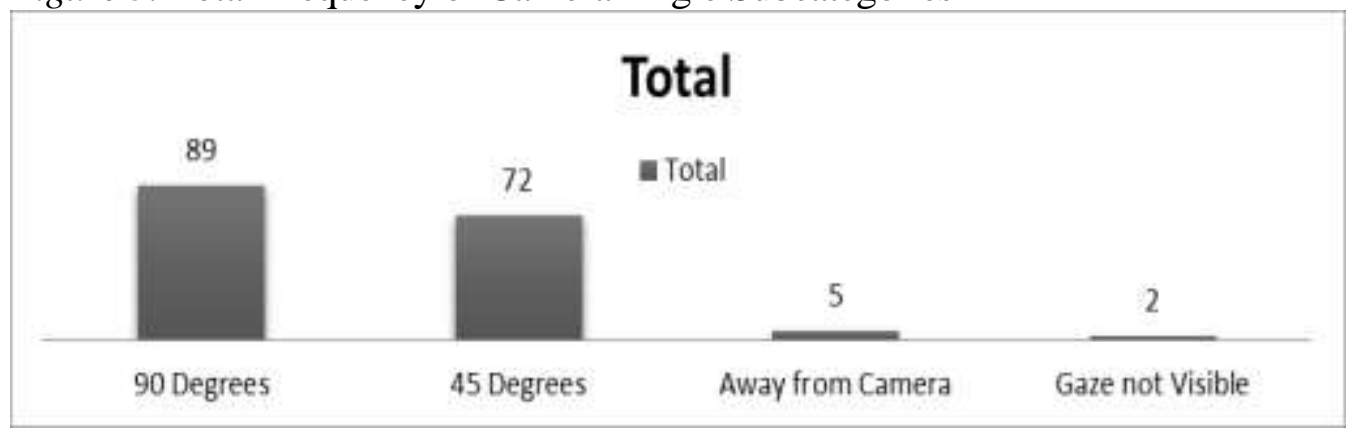

Source: Sampled newspapers, 2018.

Previous studies by Goffman (1978), Kang (1997), and Lindner (2004) touch on the issue of Licensed Withdrawal or far-off gaze, which they define as an instance where the woman is depicted as dissociating herself mentally from the situation at large or is portrayed psychologically drifting from the physical scene by withdrawing her gaze from the scene at large. Findings from this study however indicate that in total $52.97 \%$ had a direct gaze with only $2.98 \%$ of the total images sampled gazing away from the camera. The high return on 90 degrees gaze into camera as evidenced in Figure 3, suggests that the media, guided by their seemingly profit oriented philosophy establish direct eye contact between the reader and the subject, to build and sustain an intimate relationship between the two causing the former to continually want to purchase and possess the latter.

\section{Type of Clothing}

The category was divided into subcategories such as Casual (clothing suitable for an informal occasion), Formal (clothing suitable for an official occasion), 
Lingerie (underwear, nightgown, bathrobe or bikini), Traditional (Ghanaian or African clothing) and Other (does not fit the above categories).

Table 6. Frequency and Percentages of Type of Clothing Subcategories

\begin{tabular}{|l|c|c|c|c|c|c|c|c|}
\hline Subcategory & \multicolumn{2}{|c|}{ News One } & \multicolumn{2}{c|}{ Ebony } & \multicolumn{2}{c|}{ The Mirror } & \multicolumn{2}{c|}{ Total } \\
\hline & Freq. & $\%$ & Freq. & $\%$ & Freq. & $\%$ & Freq. & $\%$ \\
\hline Casual & 5 & 8.93 & 2 & 3.57 & 3 & 5.35 & 10 & 5.95 \\
\hline Formal & 4 & 7.14 & 0 & 0 & 15 & 26.79 & 19 & 11.31 \\
\hline Lingerie & 36 & 64.29 & 48 & 85.71 & 0 & 0 & 84 & 50.00 \\
\hline Traditional & 8 & 14.29 & 0 & 0 & 38 & 67.86 & 46 & 27.38 \\
\hline Other & 3 & 5.36 & 6 & 10.71 & 0 & 0 & 9 & 5.36 \\
\hline Total & $\mathbf{5 6}$ & $\mathbf{1 0 0 . 0 0}$ & $\mathbf{5 6}$ & $\mathbf{1 0 0 . 0 0}$ & $\mathbf{5 6}$ & $\mathbf{1 0 0 . 0 0}$ & $\mathbf{1 6 8}$ & $\mathbf{1 0 0 . 0 0}$ \\
\hline
\end{tabular}

Source: Sampled newspapers, 2018

Data from Table 5 show that Ebony (85.71\%) and Newsone (64.29\%) tend to portray women mostly in lingerie whereas The Mirror did not have a single image portrayed in lingerie. The Mirror however returned a high score of $67.86 \%$ under the Traditional subcategory as against $14.29 \%$ by Newsone and $0 \%$ by Ebony. The Mirror again led with $26.79 \%$ under the Formal subcategory where Newsone scored $7.14 \%$ with Ebony again returning 0\%. These finding imply that though The Mirror newspaper as a policy uses women on its front pages to entice readership as mentioned by Quainoo (2011), they are cautious about the clothing the women are presented in.

\section{Degree of Clothing}

This category examines the amount of clothing worn by the women portrayed on the front pages of the various newspapers. This category was divided further into four sub-categories Nude (woman with no clothing on), Semi Nude (woman dressed with very little clothing), Fully Dressed (woman whose dress covers most of her sensitive parts) and Other (image does not fit the above categories).

Table 7. Frequency and Percentages of Degree of Clothing Subcategories per Newspaper

\begin{tabular}{|l|c|c|c|c|c|c|c|c|}
\hline Subcategory & \multicolumn{2}{|c|}{ News One } & \multicolumn{2}{c|}{ Ebony } & \multicolumn{2}{c|}{ The Mirror } & \multicolumn{2}{c|}{ Total } \\
\hline & Freq. & $\%$ & Freq. & $\%$ & Freq. & $\%$ & Freq. & $\%$ \\
\hline Nude & 6 & 10.72 & 11 & 19.64 & 0 & 0.00 & 17 & 10.12 \\
\hline Semi Nude & 33 & 58.93 & 45 & 80.36 & 0 & 0.00 & 78 & 46.43 \\
\hline Fully Dressed & 17 & 30.36 & 0 & 0.00 & 56 & 100 & 73 & 43.45 \\
\hline Other & 0 & 0.00 & 0 & 0.00 & 0 & 0.00 & 0 & 0.00 \\
\hline Total & $\mathbf{5 6}$ & $\mathbf{1 0 0 . 0 0}$ & $\mathbf{5 6}$ & $\mathbf{1 0 0 . 0 0}$ & $\mathbf{5 6}$ & $\mathbf{1 0 0 . 0 0}$ & $\mathbf{1 6 8}$ & $\mathbf{1 0 0 . 0 0}$ \\
\hline
\end{tabular}

Source: Sampled newspapers, 2018.

News One had 6 issues (10.72\%) coded as Nude and 33 issues (58.93\%) coded as Semi Nude, Ebony also had 11 issues (19.64\%) and 45 issues (80.36\%) coded as Semi Nude, The Mirror however indicated a score of $56(100 \%)$ as Fully Dressed suggesting the state owned media was more conscious in the portrayal of female sexuality by way of clothing (Table 6). 


\section{Body Part Shown}

Body Part Shown as shown in Table 7 was coded as a follow up to Degree of Clothing and was divided under the following subcategories breast/cleavage, buttocks, genitals, legs (thighs and calves) and midsection (between chest and waist).

Table 8. Frequency and Percentages of Body Parts shown per Newspaper

\begin{tabular}{|l|c|c|c|c|c|c|}
\hline Subcategory & \multicolumn{2}{|c|}{ News One } & \multicolumn{2}{c|}{ Ebony } & \multicolumn{2}{c|}{ The Mirror } \\
\hline Breast/Cleavage & Freq. & $\%$ & Freq. & $\%$ & Freq. & $\%$ \\
\hline Buttocks & 47 & 83.93 & 49 & 87.50 & 0 & 0.00 \\
\hline Genitals & 25 & 44.64 & 44 & 78.57 & 0 & 0.00 \\
\hline Legs & 0 & 0.00 & 0 & 0.00 & 0 & 0.00 \\
\hline Midsection & 32 & 57.14 & 15 & 26.79 & 0 & 0.00 \\
\hline
\end{tabular}

Source: Sampled newspapers, 2018

According to Table 7 the Ebony and Newsone newspapers display a lot of sensitive body parts with Ebony displaying a lot of Breast/Cleavage (87.50\%) followed by Newsone (83.93\%). Under the Buttocks subcategory Ebony returned $78.57 \%$ whereas Newsone had $44.64 \%$. Newsone had 57.14 images of women under the Legs subcategory as against $26.79 \%$ for Ebony. Under the Midsection subcategory Ebony had $83.93 \%$ while Newsone had 66.07\%. The Mirror newspaper again showed that the media can display attractive images of women on the front pages without necessarily exposing their naked bodies; none of the samples coded revealed sensitive parts of the women in this category.

\section{How do Women Relate to the Images of Women as Portrayed by the Print Media?}

\section{Audience Readership}

Table 8. Percentage of Readership

\begin{tabular}{|l|c|c|c|c|}
\hline & Yes & Frequency & No & Frequency \\
\hline News One & $95 \%$ & 57 & $5 \%$ & 3 \\
\hline Ebony & $65 \%$ & 36 & $35 \%$ & 24 \\
\hline The Mirror & $80 \%$ & 48 & $20 \%$ & 12 \\
\hline
\end{tabular}

Source: Sampled newspapers, 2018.

All respondents indicated their awareness of the existence of the three newspapers selected for the study. However in terms of readership the Newsone newspaper seemed to be the most popular with 95\% (Table 8) of the respondents indicating they read it, followed by The Mirror newspaper $80 \%$ and the Ebony newspaper $65 \%$. It is important to note that all three newspapers had a readership of more than $50 \%$ an indication that respondents were familiar with the selected newspapers. 


\section{Newspapers and Stereotyping of Women}

This question was aimed at finding out if respondents per their experiences with the three newspapers felt the media stereotyped women.

Table 9. Frequency and Percentages Newspaper Stereotyping of Women in Society

\begin{tabular}{|l|c|c|}
\hline & Frequency & Percentage \\
\hline Yes & 57 & 85 \\
\hline No & 3 & 15 \\
\hline Total & $\mathbf{6 0}$ & $\mathbf{1 0 0}$ \\
\hline
\end{tabular}

Source: Sampled newspapers, 2018.

As illustrated in Table 9, 85\% of respondents answered positively to the question, suggesting that women are stereotyped by the newspapers, one of the respondents in expressing her opinion on the portrayal of women in the newspapers noted "These newspapers treat women mainly as sex objects; I find the portrayal of women in the newspapers to be offensive". Such responses evoke sentiments as expressed by Iyengar (1991) that the media have what it takes to set the agenda for people to think and talk about specific issues. People often use what is fed them by the media as reference points to decide what is and what is not, the outcome in most cases end up underpinning stereotypes.

\section{How do you think Women are Portrayed Stereotypically?}

This served as a follow up question for respondents who answered yes to the previous section they had the option of ticking more than one answer under this category.

Table 10. Frequencies and Percentages on How Women Are Stereotyped

\begin{tabular}{|l|c|c|}
\hline Stereotype & Frequency & Percentage \\
\hline Sex Objects & 51 & 85.00 \\
\hline Dependent & 0 & 0.00 \\
\hline Homemakers & 20 & 33.33 \\
\hline Submissive & 2 & 3.33 \\
\hline Assertive & 57 & 95.00 \\
\hline Independent & 57 & 95.00 \\
\hline
\end{tabular}

Source: Sampled newspapers, 2018.

As shown in Table 10, 85\% of the respondents cited women as being constructed as Sex Objects. Another 33.33\% noted that the media stereotyped women as Homemakers while $3.33 \%$ of respondents saw the media's construction of women as Submissive. This supports Stump's (2010) contention that when women are not under-represented or invisible, they are often represented in the media in traditional roles such as mothers or sexual objects. However $95 \%$ of respondents defined women as assertive and independent respectively.

In as much as respondents seem to contradict their stance by suggesting high levels of both positive and negative stereotypes it falls in line with Zimmerman 
and Dahlberg's (2008) view that the approaches of today's women toward media depiction of women can be directly linked with Third wave feminism which encourages contemporary women not to be deterred by the sexual objectification found in today's media but rather exercise their "girl power" and make their decisions impartially of how women may be portrayed by the media (p. 73).

\section{Audience Perception of the 21st Century Ghanaian Woman in Relation to the Front Pages of Newsone, Ebony and The Mirror Newspapers}

This open-ended question was meant to further find out women's perception of women as portrayed by the print media. Respondents were asked to list five ways in which they perceived women based on how they (women) were represented by the media. It must be noted that in this instance respondents were given two randomly picked samples of each newspaper to serve as a guide, unlike the coders, respondents were not limited by any predefined themes. The most recurring responses are presented in Table 11.

Table 11. Frequency and Percentages of Audience Perception of Women in Relation to Front Pages of Sampled Newspapers

\begin{tabular}{|l|c|c|}
\hline Audience Perception & Frequency & Percentage \\
\hline Sexy & 60 & 100.00 \\
\hline Mothers & 41 & 68.33 \\
\hline Wives & 44 & 73.33 \\
\hline Beautiful & 47 & 78.33 \\
\hline Professionals & 57 & 95.00 \\
\hline
\end{tabular}

Source: Sampled newspapers, 2018.

All of the respondents described Ghanaian women as sexy, $68.33 \%$ described them as mothers, $73.33 \%$ labeled them as wives while $78.33 \%$ saw them as beautiful, reechoing Stump's (2010) statement that "these sexist stereotypes in the media perpetuate a simplistic, immutable and caricatured image of women... legitimising everyday sexism and discriminatory practices and establishing a barrier to gender equality" (p. 1) and further giving credence to Mensa-Bonsu's (1992) finding that women's political and economic roles are overshadowed by their socially defined roles. The results suggest that in the view of women the print media continue to portray them in ways as found by previous studies of a similar nature (Goffman, 1978; Kang, 1997; Lindner, 2004; Baker, 2005, as cited in Ranchod, 2007, p. 43) which point to the view that stereotypical images of women still exist in the print media and that the ideologies of both patriarchy and capitalism continue to work together in supporting the pervasiveness of negative, disempowering portrayals of women.

It is encouraging however to note that $95 \%$ of respondents saw women as professionals, which supports Quainoo's (2011) contention that 21st century women have traversed the traditionally stereotyped frontier of being branded in the domestic sphere to the professional arena causing their representation and expectations to change. 


\section{Social Perception of Newspaper Portrayal of the 21st Century Ghanaian Woman (Realistic or Unrealistic)}

This question aimed at finding from respondents if media portrayal of women as suggested in a previous section was realistic or unrealistic.

Table 12. Frequency and Percentages of Respondent's Perception on how the Media Portray 21st Century Ghanaian Women (realistic or unrealistic)

\begin{tabular}{|l|c|c|}
\hline Opinion & Frequency & Percentage \\
\hline Realistic & 12 & 20 \\
\hline Unrealistic & 48 & 80 \\
\hline Not Sure & 0 & 0 \\
\hline Total & $\mathbf{6 0}$ & $\mathbf{1 0 0}$ \\
\hline
\end{tabular}

Source: Sampled newspapers, 2018.

Twenty percent of respondents, as reflected in Table 12, believed the newspapers portrayal of women was realistic arguing that since the women had decided out of their own free will to present themselves in public as seen on the front pages of the newspapers, the media could not be accused of stereotyping them.

On the other hand, $80 \%$ of the respondents argued that the media do not present a true reflection of today's Ghanaian women but only present them in such ways that would enhance the sale of their newspapers. This goes to support Carpenter and Edison's (2005) finding that the media creates and sustains unrealistic images and stereotypes of women (as cited in Cronn-Mills, 2009, p. 2) which according to Cronn-Mills (2009) is a media strategy of persuasion.

\section{The Rational for the Portrayal of Women in the Newspapers}

\section{Themes from Interviewing Editors}

The transcribed interviews generated the following themes: Organisational policy, the law and ethics, Public Perception, Stereotype, Sex sells and the 21st century Ghanaian women.

\section{Organisational Policy}

The Editor of The Mirror mentions that:

"The paper still goes by the policy of using pretty women on its cover pages to entice readership and sales. That is why in the event of featuring a man on our front page we add his spouse or a female relation".

The response supports Cronn-Mills' (2009) claim that the media know the techniques and tactics to use as a form of persuasion. 


\section{The Law and Ethics}

The interviews revealed that both editors were aware of the law how far they could go in portraying images of women within the confines of the law.

"The Mirror is a national paper; the constitution enjoins us to operate in that sense. So we are guided by the ethics of the profession". The editor's remark explains the low ranking of The Mirror newspaper in the portrayal of female sexuality as shown in Table 2.

On the other hand the editor of the private owned Newsone states that:

"I'll continue to write about sex as long as I do that within the confines of the law... once what I am doing is not against the law and I am not exposing their nudity or I am not exposing pictures they took in their private homes I don't see anything wrong with it".

The standpoint of the editor of Newsone reflects a position drawn from the guarantee of press "freedom and independence" and the protection from "censorship" as guaranteed under article 162 (1) and (2) of the 1992 Constitution, granted the media respect the fundamental human rights and freedoms of others as guaranteed under Chapter 5 of the Constitution (Article 165).

\section{Public Perception}

In addressing public perception that his paper portrays nude and seminude images of women on its front pages the editor of Newsone responded:

"There are different types of newspapers, others focus on talking about corporate women who are dressed in a three piece suit and skirt, I write about social stories and entertainment and my entertainers do not dress that way, these people are not sex objects as people see them, they are professional models who are trained to dress the way they dress for a specific purpose and a specific agenda that is the way I see all these things people talk about".

The response implies that the newspaper operates within the sociocultural world of entertainment where the exposure of the female body is regarded as normal.

\section{Stereotype}

According to Treise et al. (1994) the media industry continue to stereotype women with a major area of worry being the representation of the female gender as sex objects and the repeated use of their sex to sell products. To this the editor of The Mirror newspaper responds:

"No, no, no, The Mirror does not set out to stereotype women what the paper tries to do is to demystify that notion that women are to be kept in the background and be treated as homemakers and so on". 
On the other hand the editor of Newsone suggests a position of not seeing the sexual portrayal of women as a means of stereotyping them negatively but rather representing them as professional women.

"What the rest of the world has not realized is that I am advertising todays women who are professional models, through that advertising agencies see them and they gain more contracts... are we saying that that category of today's professional women should not be portrayed? Should not be exposed? Should not be encouraged?"

Thwaites, Davis and Mules (1995, p. 152) note that such repeated sexual exposures end up endorsing certain social values as inevitable and natural, and certain beliefs and myths about social identities and cultural norms causing them to become entrenched and take on an authority which eludes the pressure of change.

\section{Sex Sells}

According to the The Women's Manifesto for Ghana the fundamental concept of profitability can be pointed to as a factor in the continued misrepresentation of women.

In responding to this question the editor of Newsone stated:

"Why not, sex is one of the things I wouldn't describe as a soporific subject it excites me it excites you, anything that excites society sells just like soccer, just like politics, if I go and write about orchestra or Beethoven who buys it? ... So yes sex sells, am happy it sells, it puts food on my table".

The editor of The Mirror newspaper also adds that:

Yes, sex sells, but I wouldn't say we project women as sex objects for sale. The basic principle behind the industry is to sell, it is a kind of double edged sword.

The responses in line with Ranchod (2007, p. 21) reveal that the media continue to be "governed by capitalist ideology" and that "through the use of female imagery depicting sexual availability, women's bodies are exploited".

\section{The 21st Century Professional Ghanaian Woman}

Chopra's (2008) study found the print media, in respect of the 21st century woman, guilty of sexism, distortion of image of women and propagation of sex stereotypes. To this end the editor of the Newsone newspaper mentioned that:

"My paper covers a very heterogeneous audience it doesn't just refer to the woman who stays somewhere downtown Sodom and Gomorrah ${ }^{27}$ whose means of livelihood is to be a commercial head potter it also covers the young lady who's just graduated from Med [Medical] school and she works in a private clinic on the Trassaco ${ }^{28}$. So it

\footnotetext{
${ }^{27}$ A slam area in Accra the capital of Ghana, notorious for crime, drug peddling and prostitution.

${ }^{28}$ One of Accra's high society residential areas.
} 
depends on which aspect of society you are looking at, there are very professional women who have the balls of men today who are excelling from Creative Arts, to Medicine, to Politics to whatever, we also have women who are still basically relying on men for their survival. If a story is about a professional woman who is doing well we put it there as it is, if the story is about a sex worker we put it there as it is, if the story is about a professional model who has to showcase her body in a bikini for whatever professional reason she wants we put it there as it is".

This relates to Bainbridge's (1996) claim (as cited in Thurm, 2001) that the "in thing" for today's media is to project the strength of the female portrayed, mentioning that even though the media continue to parade outstandingly beautiful girls they are presented as strong women willing to take their destiny into their own hands. The editor of The Mirror also adds to Bainbridge's assertion by mentioning that:

"Today's professional woman can be found everywhere from Makola to Parliament...The Mirror makes a conscious effort to fish out for newsmakers and achievers to serve as role models to the youth especially to the young girls".

Such a claim tends to support the cause of the Women's Manifesto of Ghana, which according to Zaney (2012), has since 2004 been used by several Ghanaian and African women's right groups to advocate for social change and increase in women's presence in public life as a means to strengthen democracy and to make policy-making processes more representative of wider sections of the population.

\section{Conclusion}

The study suggests that in spite of the changing roles of women in today's society, newspapers using themes such as pose, facial expression and clothing, still portray women as sex objects for sale. The study, based on responses by the editors suggests that the media is likely to continue using of the female body as a tool for selling news. Women add that though the representations strengthen social construct, they refuse to see themselves as such.

The study calls for a combined conscious effort from government, regulatory bodies, the media and society to experience a meaningful change.

Future researchers should focus on analysing images of women from other media sources such as television or the internet, so as to present a broader picture of the representation of Ghanaian women in the media.

Furthermore, studies could be directed to a comparative study of private and state owned media portrayal of women. It is important to note that all three newspapers portrayed stereotyped images of women. However sex role depictions especially with regard to portraying women as sexy seductresses were portrayed more frequently by the two private owned newspapers.

Finally, future studies could be done to widen the scope by attempting a cross cultural study of female respondents from tertiary institutions or even a 
comparative study between female students of a public and a private university to help establish the stand of women on such portrayals.

\section{References}

Asamoah, G. (1980). The Overage of Women in Three Ghanaian Newspapers. Daily Graphic, Ghanaian Times and The Mirror (Unpublished work).

Blaha, E. (2009, November 1). The Portrayal of Women in Magazine Advertisements across Four Different Women's Magazines. Retrieved from www.kon.org.

Chopra, A. (2008, March 17). Portrayal of Women in Print Media. New Delih, Delih, India. Retrieved from http://www.responsenet.org>.

Cronn-Mills, D. (2009). Sex Sells: A Content Analysis of Women in Magazine Advertisement. Minnesota State University, Mankato.

Enu-Kwesi, F. (2006). Social Research in Policy Formulation. Centre for Development.

Gallagher, M. (n.d.). The Image Reflected by Mass Media: Stereotypes, Images of Women in the Mass Media. The Open University, United Kingdom. International Commission for the Study of Communication Problems, UNESCO.

Given, L. M. (2008). The Sage Encyclopedia of Qualitative Research Methods, Vol. 1 and 2. Ed. K. Saumure. University of Alberta, USA: Sage Publications.

Goffman, E. (1978). Gender Advertisements. Cambridge, MA: Harvard University Press.

Hammond, F. E. (1999). Portrayal of Women in the Press: A Content Analysis of The Mirror of 1994 and 1997. School of Communication Studies, University of Ghana, Legon.

Iyengar, S. (1991). Is Anyone Responsible? How Television Frames Political Issues. Chicago: University of Chicago Press.

Johnson, R. B., \& Christensen, L. B. (2008). Educational Research: Quantitative, Qualitative, and Mixed Approaches (3rd ed.). Thousand Oaks, CA: Sage Publications.

1) Jooste, C. (2007). An Analysis of the Representation of Female Athletes in selected South African Print Media from February 2006 to June 2006. Faculty of Arts at the Nelson Mandela Metropolitan University.

Kang M. E. (1997). The Portrayal of Women's Images in Magazine Advertisements: Goffman's Gender Analysis Revisited. Sex Roles, 37, 979-996.

Kimani, R. W. (2009). Does Gender Matter? A Content Analysis of the Coverage of Ghanaian Politicians by the Daily Graphic. (Master's Thesis). University of Ghana, School of Communication Studies, Legon.

Lindlof, T. R., \& Taylor, B. C. (2002). Qualitative Communication Research Methods. Thousand Oaks, Calif: Sage Publications.

Lindner, K. (2004). Images of Women in General Interest and Fashion Magazine Advertisements from 1955 to 2002. Sex Roles, 51, 390-421.

Mensa-Bonsu, F. (1992). Images of Inequality in the Media: A case Study of the Portrayal of Women in the Weekly Spectator in 1974 and 1986 (Unpublished work).

Neuendorf, K. A. (2002). The Content Analysis Guidebook. Thousand Oaks, CA: Sage Publications.

Nwagbara G. U. (2006). Cultural Stereotypes in Nigerian Print Media Advertisements. Global Journal of Humanities, 5(1\&2), 21-25.

Obenewaa, N. A. (November 7, 2007). 21Century Ghanaian Feminism: Upstaging Male Domination. Retrieved from http://www.ghanaweb.com/GhanaHomePage/News Archive/. 
Olorunpomi, G. (2011, September 27). Newspapers Should Not Publish Nude Images, Lawyers Say. Next. Retrieved from https://bit.ly/2ThVb58.

Pawlowski, I. P. (2007). Sex in Women's Magazine Advertising: An Analysis of the Degree of Sexuality in Women's Magazine Advertising across Age Demographics and Women's Responses. (Unpublished Master's Thesis). University of Canterbury

Paynter, K. C. (October, 2011). Gender Stereotypes and Representation of Female Characters in Children's Picture Books. School of Education, Liberty University. Retrieved from, http://digitalcommons.liberty.edu/cgi/viewcontent.

Pedersen, P. M. (2002). Examining Equity in Newspaper Photographs: A Content Analysis of the Print Media Photographic Coverage of Interscholastic Athletics. International Review for the Sociology of Sport 37(3-4), 303-318.

Potter, W. J. (1985). Gender Representation in Elite Newspapers. Journalism Quarterly, 62(3), 636-640.

Quainoo, K. J. (2011). The Use of Women on the Front Pages of The Mirror: How Effective in Attracting Readership? School of Communication Studies, University of Ghana, Legon.

Ranchod, A. (2007). An Investigation into the Representation of Women in South African Cosmopolitan Magazine Advertisements of 2004. Nelson Mandela Metropolitan University, School of Language, Media and Culture.

Riffe, D., Lacy, S., \& Fico, F. G. (1998). Analyzing Media Messages: Using quantitative content analysis in research. Mahwah, N.J.: Lawrence Erlbaum.

Stump, D. (2010). Combating Sexist Stereotypes in the Media. Committee on Equal Opportunities for Women and Men. Doc. 12267, Report 1, Parliamentary Assembly, Switzerland, Socialist Group. Retrieved from http//assembly.coe.int.

The Women's Manifesto for Ghana. (2004). The Coalition on the Women's Manifesto for Ghana ABANTU for Development. Retrieved from http://library.fes.de/pdffiles/bueros/ghana/02983.pdf.

Thurm, N. J. (2001). The Portrayal of Women in Advertising: Reflection or Creation of Values? Women in Advertising Research Project Paper. Introduction to Graduate Studies and Research. Retrieved from http://www.angelfire.com/ electronic2/nichole_thurm/images/Women\%20in\%2Advertising\%20\%20Researc $\mathrm{h} \% 20$ Project\%Paper.pdf

Thwaites, T., Davis, L., \& Mules, W. (1995). Tools for Cultural Studies. Palgrave, Macmillan.

Treise, D., Weigold, M. F., Conna, J., \& Garrison, H. (1994). Ethics in Advertising: Ideological Correlations of Consumer Perceptions. Journal of Advertising, 23(3), 61.

Tsegah, M. (2009). The Portrayal of Women in Televison Advertisment: A Study of Ghana Television and TV3 from January to December 2007 (Unpublished Master's Thesis). University of Ghana, School of Communication Studies, Legon.

Zaney G. D. (2012). The Portrayal of Women in the Print Media: A Study of The Mirror in 1975, 1985 and 1995. Retrieved from http://www.ghana.gov.gh/index.php/news/ general-news/16011-8th-anniversary-of-womens-manifesto-marked.

Zimmerman, A., \& Dahlberg, J. (2008). The Sexual Objectification of Women in Advertising: A Contemporary Cultural Perspective. Journal of Advertising Research, 48(1), 72.

Zwennes, S. (1996). The Portrayal of Women in the Print Media: A Study of The Mirror in 1975, 1985 and 1995. School of Communication Studies, University of Ghana, Legon. 